\title{
The Measurement of Food Insecurity in High-Income Countries: A Scoping Review
}

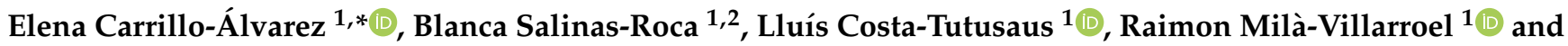 \\ Nithya Shankar Krishnan ${ }^{1}$ \\ 1 Global Research on Wellbeing (GRoW) Research Group, Blanquerna School of Health Science, Ramon Llull \\ University, Padilla, 326-332, 08025 Barcelona, Spain; blancasr@blanquerna.url.edu (B.S.-R.); \\ lluisct@blanquerna.url.edu (L.C.-T.); raimonmv@blanquerna.url.edu (R.M.-V.); \\ nithya.krishnan@outlook.com (N.S.K.) \\ 2 Department of Nursing and Physiotherapy, University of Lleida, Montserrat Roig 2, 25198 Lleida, Spain \\ * Correspondence: elenaca@blanquerna.url.edu
}

Citation: Carrillo-Álvarez, E.;

Salinas-Roca, B.; Costa-Tutusaus, L.; Milà-Villarroel, R.; Shankar Krishnan, $\mathrm{N}$. The Measurement of Food Insecurity in High-Income Countries: A Scoping Review. Int. J. Environ. Res. Public Health 2021, 18, 9829. https:// doi.org/10.3390/ijerph18189829

Academic Editor: Paul B. Tchounwou

Received: 29 July 2021

Accepted: 9 September 2021

Published: 17 September 2021

Publisher's Note: MDPI stays neutral with regard to jurisdictional claims in published maps and institutional affiliations.

Copyright: (c) 2021 by the authors. Licensee MDPI, Basel, Switzerland This article is an open access article distributed under the terms and conditions of the Creative Commons Attribution (CC BY) license (https:// creativecommons.org/licenses/by/ $4.0 /)$.

\begin{abstract}
The measurement of food insecurity is essential to monitor the prevalence, risk factors, consequences and effects of food insecurity and the interventions and policies implemented to tackle it. Yet, how best to apply it remains an unsettled issue due to the multifaceted and context-dependent nature of food insecurity. We report a scoping review of measures of food insecurity at the individual and household level in high-income countries with the final purpose of facilitating a catalogue of instruments to be used by both researchers and practitioners. The scoping review was conducted following the methodological framework of Arksey and O'Malley and the Joanna Briggs Institute guidelines. We included all types of documents published between 2000-2020 using instruments that estimate food insecurity at both individual and household level in high-income countries, and with respondents including adolescents, adults, and elderly. We identified a total of 23 measurement strategies being used in 33 peer-reviewed publications and 114 documents from the grey literature. Our results show that most measures focus on the access dimension of food insecurity and that further research is required to develop measures that incorporate aspects of quality of dietary intake and relevant individual, household and social conditions related to food insecurity.
\end{abstract}

Keywords: food insecurity; measurement; instruments; high-income countries; scoping review

\section{Introduction}

The 2020 edition of the Food and Agriculture Organization's (FAO) yearly report "The State of Food Security and Nutrition in the World (SOFI)" showed that food insecurity was rising. Worldwide, it was estimated that in 2019,750 million people $(9.7 \%)$ were exposed to severe levels of food insecurity and more than 3 billion people could not afford a healthy diet as a consequence of conflict and civil strife, climate variability, economic crisis, and persistent poverty and inequality [1]. The COVID-19 situation has added a further threat to food security across the globe, as a result of which 148 million additional people became severely food insecure [2]. According to the same report, less than $2.5 \%$ of the population in Europe and North America would be in this situation, but moderate and severe food insecurity levels have risen to almost 9\%, getting closer to 2014 levels. More localized analysis shows that prevalences of food insecurity in specific populations of these territories could be above 10-15\% [3-6].

Food insecurity threatens both individuals and societies, and constitutes a serious threat to public health and wider society [7]. In children, it has been associated with impaired physical and psychological development, the effects of which can persist into adolescence and adulthood. In adults, characteristic conditions of the double burden of diseases have been observed, such as the combination of nutritional deficiencies (i.e., anemia) and excess-diseases (i.e., diabetes, obesity). In addition, food insecurity can result 
in psychological burden and social stigma [8,9], and can also have socioeconomic spillovers in terms of productivity and health-care expenditure. People's experiences and how they cope with food insecurity have been extensively studied and documented by sociologists and anthropologists, and have considerably influenced our comprehension of what food insecurity entails $[10,11]$

The concept, interest in and understanding of food insecurity has evolved since it was first coined by the World Bank as a notion designated to broaden the understanding of hunger. The first definition of food security, "access by all people at all times to enough food for an active, healthy life" [12], was expanded ten years later in the World Food Summit to include recognition of the multidimensionality of the concept. Since then, food security is mostly referred to as the situation in which "all people at all times have physical, economic and social access to sufficient, safe and nutritious food to maintain a healthy and active life" [13]. Additionally, the Committee on World Food Security added in 2012 that it is supported by an environment of adequate sanitation, health services and care, allowing for a healthy and active life' [14], something that has been proven crucial [15].

The interest in hunger and food insecurity was initially in low-income (then referred to as developing) countries. However, it gathered momentum in high-income (developed) countries thanks to Kathy Radimer's seminal work at Cornell University [16], where she explored the phenomena and experiences of food insecurity in the US. Drawing on her findings and those of other scholars, the USDA adopted "the limited or uncertain availability of nutritionally adequate and safe foods, or limited or uncertain ability to acquire acceptable foods in socially acceptable ways" [17] as the definition of food insecurity, incorporating elements of contextualization to the definition of food (in)security, e.g., what is acceptable in one sociocultural environment may not be in another.

These remarks on the definitions are significant since the measurement of food insecurity draws on them. As mentioned, the definition provided by the FAO is the most commonly used and comprises of four dimensions that are necessary to achieve food security: availability, access, utilization and stability [18]. Availability refers to the supplies that are sourced for individuals to cover their dietary needs. Therefore, it is determined by food production, stock levels and net trade, and generally considered at the country-level and assessed through balance sheets. Access concerns how individuals reach the food available in their environment and is in turn conditioned by physical (i.e., transportation) and economic (i.e., prices, incomes) constraints. It is normally assessed at the household or individual level, and three domains of inadequate household-level food access are distinguished: quantity, quality and the psychological effects of inadequate quantity or quality food supply [19]. Utilization involves ensuring proper nutrition for the organism, and comprises elements such as intra-household distribution, purchase and conservation practices, food preparation, etc. As such, its measurement is generally done at the individual level. In order to achieve food security, all the former dimensions need to occur simultaneously and be stable over time. In high-income countries, the biggest constraint is found in the access dimension, and it is typically addressed through social wages, food banks, and soup kitchens [20].

The measurement of food insecurity is essential to monitor the prevalence, risk factors, consequences and effects of food insecurity and the interventions and policies implemented to tackle it. Yet, how best to apply it remains an unsettled issue mainly due to the multifaceted and context-dependent nature of food insecurity $[16,19,21,22]$. In recent years, several reviews of food insecurity measurement in high-income countries have been published in the literature [16,21-28]. With some differences in the objective of their study, databases and date of the search, as well as data retrieved, their results show how currently food insecurity is mostly assessed through multiple item questionnaires. However, these can be long, burdensome to respond and costly to implement. Moreover, most measures evaluate the access dimension of food insecurity and do not adequately capture its psychological and quality domains, nor the experience of or consequences for individuals. An additional question refers to the appropriateness of using tools developed for low- and 
middle-income countries in high-income ones, and vice versa. In view of the alarming rates of food insecurity in high-income countries, it is necessary to identify the most adequate tools to measure it, considering the nature, characteristics, and requirements of food insecurity in these contexts.

We aim at complementing and expanding these former works through a scoping review of measures of food insecurity at the individual and household level in high-income countries, which will also include the grey literature, with the final purpose of facilitating a catalogue of instruments to be used by both researchers and practitioners.

Hence, this review delves into the various types of tools that have been employed to measure food insecurity in high-income countries at the individual and household level, focusing on the following research questions: (i) What are the existent instruments available to measure food insecurity in individuals and households in high-income countries? (ii) What dimensions of food insecurity are the ones more often included and the ones that are missing? (iii) What are the typical characteristics of the instrument?, i.e., scale's origin (country, institution, and language), number of items, types of response options, psychometric features of the instrument, focus on quantity or/and quality of food, number of articles using the particular instrument, etc.? (iv) What are the differences in the measures used for different target groups based on age, i.e., adolescents, adults and elderly?

\section{Materials and Methods}

This review was conducted following the methodological framework of Arksey and O'Malley [29] and the Joanna Briggs Institute guidelines [30]. These frameworks involve key phases which include identifying the research question; identifying relevant studies; study selection; charting data; and finally collating, summarizing, and reporting results. In this case, we have not pursued the sixth phase of stakeholder consultation. Consequently, the Guidelines published by the Joanna Briggs Institute as well as the Preferred Reporting Items for scoping reviews (PRISMA-ScR) and the Preferred Reporting Items for Systematic Reviews and Meta-analysis Protocols Statement (PRISMA-P) have been also followed [31,32].

\subsection{Eligibility Criteria, Information Sources and Search Strategy}

The eligibility criteria include the following: (i) original studies, review articles, food aid and food insecurity reports published in peer reviewed journals as well as the grey literature-which include reports and statistics from government sources and NGOs, dissertations or theses, conferences and presentations, and newsletters and press articlesreporting to have used (ii) instruments that estimate food insecurity in adults at both individual and household level (iii) in high-income countries according to the World Bank [33] and with (iv) respondents including adolescents, adults and elderly. Papers reporting food insecurity prevalence or its health effects in children were excluded. No language restrictions were established, and the timeframe for inclusion was 2000-2020.

The search strategy for information sources was devised in consultation with an academic librarian along with two members of the research team with expertise in review methodology. The algorithms for search strategy focused on title, keywords and abstract. Key words included: "food insecurity", "food security", "dietary diversity", "food insufficiency", "food poverty", "measurement" OR "measure", "instrument", "scale", "questionnaire", "high-income countries", "developed countries", "individual", "household" ( ... .). Specific searches for each database can be found in Supplementary Materials File S1.

For the peer-reviewed literature, the following medical and social science bibliographic databases were searched: Cochrane Central Register of Controlled Trials (CENTRAL), Medline (PubMed), Embase, CINAHL, FSTA, PsycINFO, Scopus, Sociological Abstracts and Web of Science Core Collection. The reference list of the eligible papers was scanned for additional registries.

The search for the grey literature was conducted by two research team members. Since there is not yet a gold standard for the grey literature, the search was carried out 
mainly via search engines such as Google, Google Scholar and OpenGray. Specific steps and recommended resources for searching the grey literature were followed [34]. To ensure that a large amount of the of grey literature was included, the search was also extended to specific websites which provided information on food insecurity such as FAO, USDA, UNICEF, WHO, etc. In addition, top university websites of the world offering a comprehensive list of grey literature databases such as DOAR, ELDIS, Factiva, periodicals index online were also searched.

\subsection{Study Selection}

For the screening and final selection of peer-reviewed journals, the software tool COVIDence was employed. This included uploading the peer-reviewed journals along with the full texts on COVIDence. Based on the suggestions of Arskey and O'Malley, the identification and selection of studies were a comprehensive and iterative process, which included weekly meetings in order to discuss the different phases and improve and direct the diverse aspects under agreement. Firstly, four research team members independently screened the titles and abstracts of the studies based on the eligibility criteria of this review. Based on a consensus, those documents which did not meet the eligibility criteria were eliminated from the study. Next, full texts of all potentially relevant documents were reviewed by the same four reviewers. Based on the consensus, few papers were eliminated. The process was reported following a flow chart from the extension for Scoping Reviews (PRISMA-ScR) [31], as shown in Figure 1.
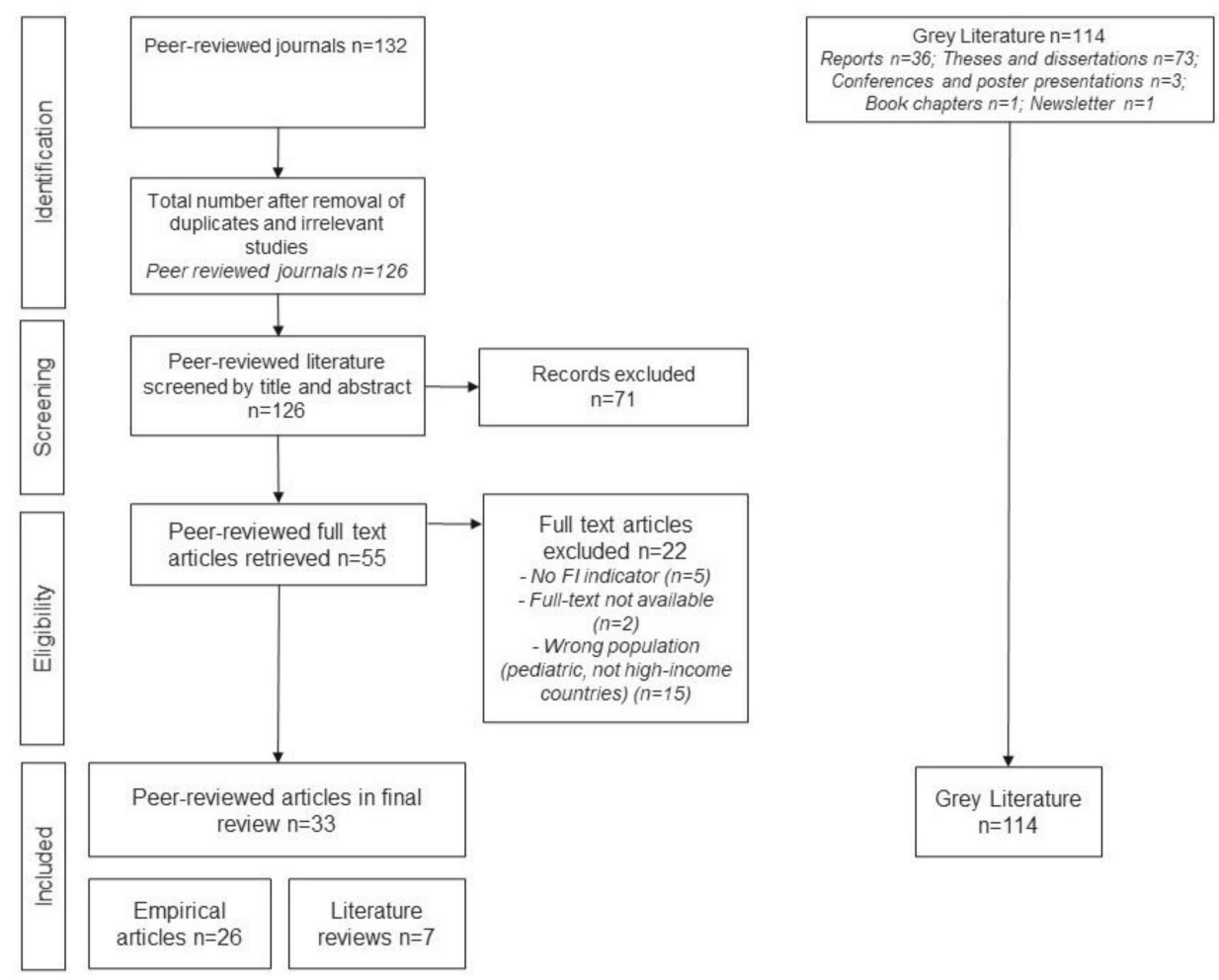

Figure 1. Flow diagram of study selection process. FI: Food insecurity.

\subsection{Data Charting}

Data were extracted, by pairs, by four members of the research team, and compared. A standardized form created by the research team was employed to input the data into Microsoft Excel Spreadsheets which was, based on the iterative process described above, continuously updated throughout the search strategy. 
The data extracted for the peer-reviewed and grey literature was based on the following: title, author, year of publication, journal; country of development of the study; specific food insecurity indicator or indicators used; study population characteristics (age, country, household or individuals, respondents); procedure of data collection in the study (only in the peer-reviewed literature); results of the study.

\subsection{Analysis of Results}

The main findings were summarized using a narrative descriptive synthesis approach. A table containing relevant information about the different food insecurity measurement tools extracted from the selected peer-reviewed journals and grey literature of this review was completed, containing the name of the food insecurity instrument, its author/s and year; languages in which the instrument has been developed/translated; original purpose of development; unit to collect food insecurity data, i.e., individual or household; reference period of the assessment of food insecurity; dimensions of food insecurity; number of items; psychometric properties; types of response options and food insecurity classification; focus on quality and/or quantity of food intake; references in the review that have employed this particular instrument along with the country and level of food insecurity (individualhousehold); and strengths and limitations of this instrument. Data regarding the strengths and limitations of the instruments were retrieved from the documents using them as well as the documents reporting the creation and/or validation of their own measures.

\section{Results}

We initially identified 246 records -132 from the scientific literature and 114 from the grey literature. After removing duplicates and irrelevant studies from the scientific literature, 240 documents ( 126 from peer reviewed journals, 114 from the grey literature) were moved to the screening phase. Title and abstract screening eliminated 77 documents from the peer-reviewed literature. Afterwards, the remaining 55 records were assessed for eligibility using full text. Finally, 33 publications from the scientific literature were included (Figure 1), which comprised original articles $(n=26)$, literature reviews $(n=7)$, and the 114 documents from the grey literature.

Overall, these 147 documents reported data on food insecurity at the household level and individual level in high-income countries using a total of 23 measurement strategies.

In this section, we first describe the overall characteristics of the studies reported in these documents, separating the scientific and grey literature, to subsequently proceed to the depiction of the 23 measurements found in our sample.

\subsection{Peer-Reviewed Literature}

Table 1 shows the basic data of the peer-reviewed literature included in this scoping review. Over $90 \%$ of the reviewed empirical studies were conducted after 2015 (only [35,36] were published before that date). Eleven papers reported data on more than one country, with six of them including global samples of more than 100 countries [37-42], while the others used data from Europe [43], Macedonia, Moldova and Romania [44], and a combination of US and Canada [45]. The rest of the the papers used samples based in one country: US [35,46-49], Australia [50,51], Portugal [36,52], Canada [43,53,54], France [55], Greece [56], Italy [57], Norway [58] and Poland [59]. The remaining seven documents were literature reviews with no geographic restrictions, except for $[60,61]$ which focused on combinations of US, Canada, England, New Zealand and Australia.

Three original papers explored the validity of new or existing food insecurity measures $[37,39,51]$, while all others explored reported data on food insecurity prevalence with a different focus. Some studied its correlates: sociodemographics [40,58,59], age [52], health, social and poverty stressors [35] and self-confidence in resource management [47]; disparities based on gender [38,42,48], race [46] or region [36]; its health consequences [44,53,57,62]; and the impact of different policies and strategies $[43,45,49,54-56,63]$. The literature reviews' objective was primarily to identify measurement tools available $[16,21-23,60]$, although 
one of them also reviewed studies about food insecurity and environmental correlates [64], and another focused on gender disparities [61].

Fourteen original papers reported food insecurity at the household level $[36,43-45,47,49,51-56,59,65]$ and twelve at the individual level, with only Park et al. [40] not focusing on the adult population (they collect data on the elderly). Literature reviews included both household and individual measures.

Instruments to assess household food insecurity included the 18-item Household Food Security Survey Module from USDA (18-HFSSM) [45,47,53-55,65], the Brazilian Food Insecurity Scale [36,52], the Household Food Insecurity Access Scale [59], the Food Security Survey Module (FSSM) [56], the Food Insecurity Index (FII) [49], the Household Hunger Scale (HHS) [44], the Healthy Diets ASAP [51] and the European Quality of Life Survey item "could your household afford a meal with meat, chicken or fish every second day if you wanted it?" [43]. Food Insecurity at the individual level was measured through the Food Insecurity Experience Scale (FIES), mostly through the Gallup World Survey $[37-40,42,62]$, the six or ten-item Household Food Security Survey Module from USDA (6-HFSSM; 10-HFSSM) [35,46,48], the 10-item Radimer-Cornell Scale [58], the Household Food Insecurity Access Scale (HFIAS) [57] and an ad hoc developed single-item measure [50]. Other scales identified by the review papers include the Community Childhood Hunger Identification Project (CCHIP), the single-item National Health and Nutrition Examination Survey (NHANES-III), the USDA Food Insufficiency Question, the 10-item AFSSM, adapted HFSSM, the Australian National Health Survey single-item measure, the Household Food and Nutrition Security Survey (HFNSS), the USDA Food Insecurity and Hunger Scale, the New Zealand measure of individual deprivation, the Hager 2-item Food Insecurity Screening Questions, the Girard four point tool, the Kuyper past food insecurity screening, the Townsend Food Behaviour Checklist and other multi or single item measures.

Of the original studies using primary data (not previously existing surveys), the vast majority collected food insecurity information in face-to-face interviews. The study by Koh et al. [46] also uses online data collection. In those papers based on data from the GWP, food insecurity instruments are administered either face-to-face or via telephone. Nettle and Bateson's [48] study also combines these two methods of data collection. Last, the procedure of data collection is not clearly stated for some studies, although is very likely that measurements have been taken in person $[47,49,50,66,67]$. 
Table 1. Overview of scientific literature of food insecurity studies: original articles and literature reviews.

\begin{tabular}{|c|c|c|c|c|c|c|c|c|c|}
\hline Title & Author/s & Year & Journal & $\begin{array}{c}\text { FI } \\
\text { Measure }\end{array}$ & Country & Objective & $\begin{array}{l}\text { Households/ } \\
\text { Individuals }\end{array}$ & $\begin{array}{c}\text { Data Collection } \\
\text { Procedure }\end{array}$ & Results \\
\hline $\begin{array}{c}\text { An Examination } \\
\text { of Measurement } \\
\text { Invariance Using a } \\
\text { Multilevel } \\
\text { Explanatory Rasch } \\
\text { Model }\end{array}$ & $\begin{array}{c}\text { Jue Wang, Victoria } \\
\text { T. Tanaka, George } \\
\text { Engelhard Jr. and } \\
\text { Matthew P. } \\
\text { Rabbitt [37] }\end{array}$ & 2020 & $\begin{array}{l}\text { Measurement: } \\
\text { Interdisciplinary } \\
\text { Research and } \\
\text { Perspectives }\end{array}$ & FIES & 151 countries & $\begin{array}{l}\text { To assess whether there } \\
\text { is DIF in the FIES Scale } \\
\text { due to gender and if so, } \\
\text { to what extent. To study } \\
\text { whether controlling for } \\
\text { differences in the } \\
\text { severity of latent food } \\
\text { insecurity associated } \\
\text { with person-level } \\
\text { explanatory variables } \\
\text { have an impact on the } \\
\text { detection of gender DIF } \\
\text { in the FIES Scale? }\end{array}$ & Individuals & $\begin{array}{l}\text { Gallup survey (see } \\
\text { note) }\end{array}$ & $\begin{array}{l}\text { The results indicated the } \\
\text { presence of differential item } \\
\text { functioning for gender on the } \\
\text { pooled (global) FIE Scale. Several } \\
\text { person-level explanatory } \\
\text { variables (educational attainment } \\
\text { and socioeconomic status) also } \\
\text { explained a significant amount of } \\
\text { the variation in food insecurity } \\
\text { measures. Furthermore, separate } \\
\text { analyses were conducted for six } \\
\text { geographic regions of the world, } \\
\text { showing gender-related DIF, as } \\
\text { well as the impact of person-level } \\
\text { explanatory variables across the } \\
\text { geographic regions }\end{array}$ \\
\hline $\begin{array}{l}\text { Confirmatory } \\
\text { factor analysis to } \\
\text { validate a new } \\
\text { measure of food } \\
\text { insecurity: } \\
\text { Perceived and } \\
\text { actual constructs }\end{array}$ & $\begin{array}{c}\text { ElenaGrimaccia, } \\
\text { Alessia } \\
\text { Naccarato [39] }\end{array}$ & 2020 & $\begin{array}{l}\text { Quality and } \\
\text { Quantity }\end{array}$ & FIES & 147 countries & To validate the FIES & Individuals & Gallup survey & $\begin{array}{l}\text { FIES presents a good level of } \\
\text { reliability and internal } \\
\text { consistency. However, two } \\
\text { distinct latent constructs were } \\
\text { identified and analysed: A } \\
\text { subscale measuring 'perceived' } \\
\text { aspects of food insecurity and a } \\
\text { subscale related to 'actually } \\
\text { experienced' activities }\end{array}$ \\
\hline $\begin{array}{l}\text { Food Insecurity in } \\
\text { Europe: A Gender } \\
\text { Perspective }\end{array}$ & $\begin{array}{c}\text { ElenaGrimaccia, } \\
\text { Alessia } \\
\text { Naccarato [38] }\end{array}$ & 2020 & $\begin{array}{l}\text { Social Indicators } \\
\text { Research }\end{array}$ & FIES & 147 countries & $\begin{array}{l}\text { To analyze the principal } \\
\text { determinants of gender } \\
\text { differences in food } \\
\text { insecurity }\end{array}$ & Individuals & $\begin{array}{l}\text { Gallup survey (see } \\
\text { note) }\end{array}$ & $\begin{array}{l}\text { The results suggest that the } \\
\text { driver that could most mitigate } \\
\text { women disadvantage is } \\
\text { education: people with a } \\
\text { university degree present a lower } \\
\text { probability of experiencing food } \\
\text { insecurity, both for men and for } \\
\text { women. On the contrary, familial } \\
\text { characteristics, such as the } \\
\text { number of children in the } \\
\text { household, present a higher } \\
\text { impact on women's food } \\
\text { insecurity than men. }\end{array}$ \\
\hline
\end{tabular}


Table 1. Cont

\begin{tabular}{|c|c|c|c|c|c|c|c|c|c|}
\hline Title & Author/s & Year & Journal & $\begin{array}{c}\text { FI } \\
\text { Measure }\end{array}$ & Country & Objective & $\begin{array}{l}\text { Households/ } \\
\text { Individuals }\end{array}$ & $\begin{array}{c}\text { Data Collection } \\
\text { Procedure }\end{array}$ & Results \\
\hline $\begin{array}{l}\text { Food Insecurity } \\
\text { among } \\
\text { Small-Scale } \\
\text { Farmersin Poland }\end{array}$ & $\begin{array}{c}\text { Agnieszka } \\
\text { Poczta-Wajda, } \\
\text { Agnieszka Sapa, } \\
\text { Sebastian Stepien, } \\
\text { Michał } \\
\text { Borychowski [59] }\end{array}$ & 2020 & Agriculture & HFIAS & Poland & $\begin{array}{l}\text { To examine the level of } \\
\text { food insecurity among } \\
\text { small-scale farms in } \\
\text { Poland }\end{array}$ & Household & $\begin{array}{c}\text { Face-to-face } \\
\text { interviews }\end{array}$ & $\begin{array}{l}\text { The incidence and degree of food } \\
\text { insecurity was measured with } \\
\text { the Household Food Insecurity } \\
\text { Access Scale (HFIAS). The study } \\
\text { found that about } 43 \% \text { of the } \\
\text { respondents were exposed to } \\
\text { food insecurity, including almost } \\
9 \% \text { to severe food insecurity, } \\
\text { which is well above the average } \\
\text { for the entire Polish population. } \\
\text { By applying cross-tabulation and } \\
\text { the zero-inflated Poisson } \\
\text { regression model, the study } \\
\text { found that the higher age and } \\
\text { secondary or higher education of } \\
\text { the farm manager, having } \\
\text { children in the household and } \\
\text { higher land productivity have a } \\
\text { statistically significant negative } \\
\text { influence on households' food } \\
\text { insecurity (i.e., decreased HFIAS } \\
\text { score). On the contrary, family } \\
\text { size of five or more and } \\
\text { production type "permanent } \\
\text { crops" and "dairy cows" have a } \\
\text { statistically significant positive } \\
\text { influence on households' food } \\
\text { insecurity (i.e., increased HFIAS } \\
\text { score). }\end{array}$ \\
\hline
\end{tabular}


Table 1. Cont.

\begin{tabular}{|c|c|c|c|c|c|c|c|c|c|}
\hline Title & Author/s & Year & Journal & $\begin{array}{c}\text { FI } \\
\text { Measure }\end{array}$ & Country & Objective & $\begin{array}{l}\text { Households/ } \\
\text { Individuals }\end{array}$ & $\begin{array}{l}\text { Data Collection } \\
\text { Procedure }\end{array}$ & Results \\
\hline $\begin{array}{c}\text { Explaining racial } \\
\text { inequality in food } \\
\text { security in } \\
\text { Columbus, Ohio: } \\
\text { A blinder-oaxaca } \\
\text { decomposition } \\
\text { analysis }\end{array}$ & $\begin{array}{l}\text { Keumseok Koh, } \\
\text { Michelle L. Kaiser, } \\
\text { Glennon Sweeney, } \\
\text { Karima Samadi } \\
\text { and Ayaz } \\
\text { Hyder [46] }\end{array}$ & 2020 & $\begin{array}{l}\text { International } \\
\text { Journal of } \\
\text { Environmental } \\
\text { Research and } \\
\text { Public Health }\end{array}$ & $\begin{array}{l}\text { 6-item } \\
\text { HFSSM } \\
\text { (USDA) }\end{array}$ & USA & $\begin{array}{l}\text { Using Blinder-Oaxaca BO } \\
\text { approach, this study aims to } \\
\text { divide the Black-White food } \\
\text { security differential into a part } \\
\text { that is "explained" by group } \\
\text { differences in socioeconomic } \\
\text { characteristics, food shopping } \\
\text { behaviors, and neighborhood } \\
\text { perception and a remaining } \\
\text { part that cannot be accounted } \\
\text { for by such differences in the } \\
\text { known determinants of food } \\
\text { security in Columbus, Ohio. }\end{array}$ & $\begin{array}{l}\text { Individuals } \\
\text { (adults) }\end{array}$ & $\begin{array}{l}\text { In-person or } \\
\text { online survey }\end{array}$ & $\begin{array}{l}\text { Compared with Black } \\
\text { households, White households } \\
\text { used their own cars more often } \\
\text { and walk less to buy food, } \\
\text { shopped } 1.4 \text { times more } \\
\text { frequently, and travelled } \\
\text { 0.6 miles less to acquire food in } \\
\text { one month. Regarding } \\
\text { neighborhood perception, White } \\
\text { households were more satisfied } \\
\text { with food accessibility in their } \\
\text { neighborhood, and had more } \\
\text { perceived connections with } \\
\text { friends and neighbors in their } \\
\text { communities. In terms of } \\
\text { socioeconomic characteristics, } \\
\text { White respondents were younger, } \\
\text { possessed higher educational } \\
\text { and household income levels, } \\
\text { had fewer children in their } \\
\text { homes, and were less likely to } \\
\text { participate in SNAP. There was a } \\
\text { 34.2 percent point (95\% CI: } \\
\text { 25.4-43.1) difference in food } \\
\text { security between White and } \\
\text { Black households. }\end{array}$ \\
\hline $\begin{array}{l}\text { Caregiver's } \\
\text { self-confidence in } \\
\text { food resource } \\
\text { management is } \\
\text { associated with } \\
\text { lower risk of } \\
\text { household food } \\
\text { insecurity among } \\
\text { SNAP-Ed-eligible } \\
\text { head start families }\end{array}$ & $\begin{array}{l}\text { Lamis Jomaa, } \\
\text { Muzi Na, Sally G. } \\
\text { Eagleton, Marwa } \\
\text { Diab-El-Harake } \\
\text { and Jennifer S. } \\
\text { Savage [47] }\end{array}$ & 2020 & Nutrients & $\begin{array}{l}\text { 18-item } \\
\text { HFSSM } \\
\text { (USDA) }\end{array}$ & USA & $\begin{array}{l}\text { The present study aimed to } \\
\text { first examine the associations } \\
\text { between Food Resource } \\
\text { Management (FRM) } \\
\text { self-confidence and FRM } \\
\text { behaviors by HFI status using } \\
\text { a sample of SNAP-Ed-eligible } \\
\text { Head Start families. A } \\
\text { secondary objective of the } \\
\text { study was to explore the } \\
\text { association between financial } \\
\text { practices of caregivers and HFI } \\
\text { status in the study sample. }\end{array}$ & Households & $\begin{array}{l}\mathrm{N} / \mathrm{A}(\text { most likely } \\
\text { in person) }\end{array}$ & $\begin{array}{l}\text { Participants with high FRM } \\
\text { self-confidence had lower odds } \\
\text { of HFI (OR }=0.54,95 \% \text { CI: } 0.33 \text {, } \\
\text { 0.87), yet FRM behaviors, } \\
\text { financial practices, and HFI were } \\
\text { not related after adjusting for } \\
\text { covariates. All FRM } \\
\text { self-confidence questions } \\
\text { significantly differed by HFI, } \\
\text { whereas only one of six FRM } \\
\text { behaviors and two of three } \\
\text { financial practices differed by } \\
\text { HFI (all } p \text {-values }<0.05) \text {. }\end{array}$ \\
\hline
\end{tabular}


Table 1. Cont.

\begin{tabular}{|c|c|c|c|c|c|c|c|c|c|}
\hline Title & Author/s & Year & Journal & $\begin{array}{c}\text { FI } \\
\text { Measure }\end{array}$ & Country & Objective & $\begin{array}{l}\text { Households/ } \\
\text { Individuals }\end{array}$ & $\begin{array}{l}\text { Data Collection } \\
\text { Procedure }\end{array}$ & Results \\
\hline $\begin{array}{l}\text { Association of } \\
\text { maternal food } \\
\text { insecurity before } \\
\text { and during } \\
\text { pregnancy with } \\
\text { fetal structural } \\
\text { anomalies: A } \\
\text { multicenter } \\
\text { case-control study } \\
\text { protocol }\end{array}$ & $\begin{array}{c}\text { Drieda Zac, Ilda } \\
\text { Hoxhaj, } \\
\text { TinaPasciuto, } \\
\text { Rosario D'Anna, } \\
\text { Gianluca Straface, } \\
\text { Laura Reali, } \\
\text { Marco De Santis } \\
\text { and Maria Luisa } \\
\text { Di Pietro } \\
\text { [57] }\end{array}$ & 2020 & $\begin{array}{l}\text { Nutrition and } \\
\text { Health }\end{array}$ & HFIAS & Italy & $\begin{array}{l}\text { The primary objective of } \\
\text { the study was to } \\
\text { investigate the impact of } \\
\text { food insecurity among } \\
\text { pregnant women before } \\
\text { and during pregnancy } \\
\text { on fetal structural } \\
\text { anomalies Secondary } \\
\text { objectives. Secondary } \\
\text { objectives are to evaluate } \\
\text { the prevalence of food } \\
\text { insecurity among } \\
\text { pregnant women in the } \\
\text { study population, and to } \\
\text { evaluate the prevalence } \\
\text { of different types of fetal } \\
\text { structural anomalies in } \\
\text { the case group. }\end{array}$ & Individuals & $\begin{array}{l}\mathrm{N} / \mathrm{A} \text { (most likely } \\
\text { in person) }\end{array}$ & $\begin{array}{l}\text { Finding a positive association } \\
\text { between food insecurity in } \\
\text { pregnant women and fetal } \\
\text { structural anomalies could be the } \\
\text { first step towards screening for it } \\
\text { among pregnant women and } \\
\text { designing policies that could } \\
\text { mitigate this condition. } \\
\text { Lowering food insecurity could } \\
\text { prevent a certain number of fetal } \\
\text { structural anomalies, leading to } \\
\text { fewer negative pregnancy } \\
\text { outcomes and health problems } \\
\text { during childhood and adulthood }\end{array}$ \\
\hline $\begin{array}{l}\text { Hunger in } \\
\text { Vulnerable } \\
\text { Families in } \\
\text { Southeastern } \\
\text { Europe: } \\
\text { Associations With } \\
\text { Mental Health and } \\
\text { Violence }\end{array}$ & $\begin{array}{c}\text { Jansen, Elena; } \\
\text { Lachman, Jamie } \\
\text { M; Heinrichs, } \\
\text { Nina; Hutchings, } \\
\text { Judy; Baban, } \\
\text { Adriana; Foran, } \\
\text { Heather M } \\
\text { [44] }\end{array}$ & 2020 & $\begin{array}{c}\text { Frontiers in Public } \\
\text { Health }\end{array}$ & $\begin{array}{l}\text { Hunger } \\
\text { Scale }\end{array}$ & $\begin{array}{l}\text { North Macedonia, } \\
\text { Republic of } \\
\text { Moldova and } \\
\text { Romania }\end{array}$ & $\begin{array}{l}\text { This study explored the } \\
\text { experience of hunger in } \\
\text { vulnerable families in } \\
\text { three South-eastern } \\
\text { European countries, and } \\
\text { simultaneously } \\
\text { examined relationships } \\
\text { with four sets of risk } \\
\text { factors-lack of financial, } \\
\text { mental, familial, and } \\
\text { social resources }\end{array}$ & Household & $\begin{array}{l}\text { Data collection } \\
\text { took place either } \\
\text { at participants' } \\
\text { homes, the study } \\
\text { institutes or any } \\
\text { agreed-on } \\
\text { location. }\end{array}$ & $\begin{array}{l}\text { Hunger in South-eastern } \\
\text { European families, among } \\
\text { families with children showing } \\
\text { elevated behavioral problems, } \\
\text { was associated with more family } \\
\text { violence, } \\
\text { but specifically poorer mental } \\
\text { health and less emotional } \\
\text { support above and beyond } \\
\text { socio-structural strains. } \\
\text { Adapting parenting } \\
\text { interventions to support the } \\
\text { primary caregiver in getting } \\
\text { more access to emotional support } \\
\text { may potentially also change } \\
\text { hunger and its association with } \\
\text { health and violence. However, } \\
\text { this hypothetical pathway of } \\
\text { change needs explicit testing }\end{array}$ \\
\hline
\end{tabular}


Table 1. Cont.

\begin{tabular}{|c|c|c|c|c|c|c|c|c|c|}
\hline Title & Author/s & Year & Journal & $\begin{array}{c}\text { FI } \\
\text { Measure }\end{array}$ & Country & Objective & $\begin{array}{l}\text { Households/ } \\
\text { Individuals }\end{array}$ & $\begin{array}{c}\text { Data Collection } \\
\text { Procedure }\end{array}$ & Results \\
\hline $\begin{array}{l}\text { What explains } \\
\text { gender differences } \\
\text { in food insecurity? }\end{array}$ & $\begin{array}{l}\text { Nzinga H. } \\
\text { Broussard } \\
\text { [42] }\end{array}$ & 2020 & Food Policy & FIES & $\begin{array}{l}2014 \text { round of the } \\
\text { GWP for } 146 \\
\text { countries }\end{array}$ & $\begin{array}{l}\text { To assess whether there } \\
\text { are gender differences in } \\
\text { FI }\end{array}$ & Individuals & $\begin{array}{c}\text { Interviews are } \\
\text { conducted either } \\
\text { face-to-face or via } \\
\text { telephone. } \\
\text { Telephone surveys } \\
\text { are conducted in } \\
\text { countries with at } \\
\text { least } 80 \% \\
\text { telephone } \\
\text { coverage. }\end{array}$ & $\begin{array}{l}\text { In the developed countries of the } \\
\text { European Union, women are } \\
\text { 4.7 percentage points more likely } \\
\text { than men to experience some } \\
\text { form of food insecurity. In the } \\
\text { poor countries of South Asia and } \\
\text { Sub-Saharan Africa, women are } \\
\text { two percentage points more } \\
\text { likely than men to be severely } \\
\text { food insecure }\end{array}$ \\
\hline $\begin{array}{l}\text { Heterogeneous } \\
\text { factors predict } \\
\text { food insecurity } \\
\text { among the elderly } \\
\text { in developed } \\
\text { countries: Insights } \\
\text { from a } \\
\text { multi-national } \\
\text { analysis of } 48 \\
\text { countries }\end{array}$ & $\begin{array}{c}\text { Jae Yeon Park, } \\
\text { Arlette Saint Ville, } \\
\text { Timothy } \\
\text { Schwinghamer, } \\
\text { Hugo } \\
\text { Melgar-Quiñonez } \\
\text { [68] }\end{array}$ & 2019 & Food Security & FIES & 48 countries (GWP) & $\begin{array}{l}\text { (1) to examine } \\
\text { macro-level prevalence } \\
\text { of food insecurity } \\
\text { among the elderly in } 48 \\
\text { developed countries. } \\
\text { (2) to assess possible risk } \\
\text { factors affecting food } \\
\text { insecurity by the elderly } \\
\text { in developed countries, } \\
\text { using cross-nationally } \\
\text { comparative methods. }\end{array}$ & $\begin{array}{l}\text { Individuals } \\
\text { (elderly) }\end{array}$ & Gallup survey & $\begin{array}{l}\text { Food insecure individuals were } \\
\text { more likely to live alone, not } \\
\text { have a partner, and tended to } \\
\text { have poorer scores for social } \\
\text { support and wellbeing. } \\
\text { Additionally, poor community } \\
\text { infrastructure was associated } \\
\text { with food insecurity of elderly } \\
\text { people, and there were more } \\
\text { food insecure elderly people in } \\
\text { urban areas. At the multinational } \\
\text { level, results indicated wide and } \\
\text { statistically significant disparities } \\
\text { among continents. The study } \\
\text { concluded that not only personal } \\
\text { factors but also social conditions } \\
\text { could prevent the elderly from } \\
\text { achieving full } \\
\text { food security status. }\end{array}$ \\
\hline
\end{tabular}


Table 1. Cont

\begin{tabular}{|c|c|c|c|c|c|c|c|c|c|}
\hline Title & Author/s & Year & Journal & $\begin{array}{c}\text { FI } \\
\text { Measure }\end{array}$ & Country & Objective & $\begin{array}{l}\text { Households/ } \\
\text { Individuals }\end{array}$ & $\begin{array}{c}\text { Data Collection } \\
\text { Procedure }\end{array}$ & Results \\
\hline $\begin{array}{l}\text { "I worry if I will } \\
\text { have food } \\
\text { tomorrow": A } \\
\text { study on food } \\
\text { insecurity among } \\
\text { asylum } \\
\text { seekers living in } \\
\text { Norway }\end{array}$ & $\begin{array}{c}\text { Sigrun Henjum, } \\
\text { Marianne } \\
\text { Sandsmark } \\
\text { Morseth, Charles } \\
\text { D. Arnold, Dawid } \\
\text { Mauno, Laura } \\
\text { Terragni } \\
\text { [58] }\end{array}$ & 2019 & $\begin{array}{c}\text { BMC Public } \\
\text { Health }\end{array}$ & $\begin{array}{l}\text { 10-item } \\
\text { Radimer/Cornell } \\
\text { Hunger } \\
\text { and Food } \\
\text { Insecurity } \\
\text { Scale }\end{array}$ & Norway & $\begin{array}{l}\text { to assess food security } \\
\text { among asylum seekers } \\
\text { living in Norwegian } \\
\text { reception centers }\end{array}$ & individuals & Face-to-face & $\begin{array}{l}\text { Seven percent of the participants } \\
\text { were categorized as food secure } \\
\text { and } 93 \% \text { as food insecure, of } \\
\text { whom } 11 \% \text { were food insecure } \\
\text { without hunger, } 78 \% \text { were food } \\
\text { insecure with hunger, and } 4 \% \\
\text { were food insecure with child } \\
\text { hunger. Among the families with } \\
\text { children, } 20 \% \text { ( } 8 \text { of } 41 \text { ) } \\
\text { experienced child hunger. For } \\
\text { the participants experiencing } \\
\text { food insecurity with hunger, } 44 \% \\
\text { reported that they were hungry } \\
\text { often, and among families with } \\
\text { children, } 14 \% \text { reported that } \\
\text { despite being aware of the child's } \\
\text { hunger, they did not have the } \\
\text { resources / money to buy more } \\
\text { food. In logistic regression } \\
\text { models, men had higher odds of } \\
\text { experiencing adult food } \\
\text { insecurity with hunger than } \\
\text { women, OR (95\% CI): } 4.08 \text { ( } 2.04, \\
8.16) \text {. A reduction in monthly } \\
\text { budget by } 100 \text { euros increased } \\
\text { the odds of experiencing adult } \\
\text { food in-security with hunger by } \\
1.37 \text { times OR (95\% CI), } 1.37 \\
\text { (1.16, } 1.61)\end{array}$ \\
\hline
\end{tabular}


Table 1. Cont.

\begin{tabular}{|c|c|c|c|c|c|c|c|c|c|}
\hline Title & Author/s & Year & Journal & $\begin{array}{c}\text { FI } \\
\text { Measure }\end{array}$ & Country & Objective & $\begin{array}{l}\text { Households/ } \\
\text { Individuals }\end{array}$ & $\begin{array}{c}\text { Data Collection } \\
\text { Procedure }\end{array}$ & Results \\
\hline $\begin{array}{l}\text { Food-Insecure } \\
\text { Women Eat a Less } \\
\text { Diverse Diet in a } \\
\text { More Temporally } \\
\text { Variable Way: } \\
\text { Evidence from the } \\
\text { US National } \\
\text { Health and } \\
\text { Nutrition } \\
\text { Examination } \\
\text { Survey, 2013-4 }\end{array}$ & $\begin{array}{c}\text { Daniel Nettle and } \\
\text { Melissa Bateson } \\
\text { [48] }\end{array}$ & 2019 & Journal of Obesity & $\begin{array}{l}\text { 10-item } \\
\text { HFSSM }\end{array}$ & USA & $\begin{array}{l}\text { we investigated in detail } \\
\text { the } 24 \text {-h. } \\
\text { food-consumption } \\
\text { recalls of adult women } \\
\text { in the 2013-4 cycle of } \\
\text { NHANES. Like previous } \\
\text { studies, we extracted } \\
\text { variables concerning } \\
\text { total energy intake, } \\
\text { macronutrient } \\
\text { composition, and } \\
\text { number of eating } \\
\text { occasions in the day. }\end{array}$ & Individuals & $\begin{array}{l}\text { two separate food } \\
\text { recall interviews, } \\
\text { the first in person } \\
\text { and the second by } \\
\text { telephone }\end{array}$ & $\begin{array}{l}\text { Compared to the food-secure, } \\
\text { food-insecure women had more } \\
\text { variable time gaps between } \\
\text { eating; ate a smaller and less } \\
\text { variable number of distinct foods } \\
\text { at a time; were more variable } \\
\text { from day to day in their time of } \\
\text { first consumption; were more } \\
\text { variable from day to day in the } \\
\text { number of times they ate; and } \\
\text { consumed relatively more } \\
\text { carbohydrate, less protein, and } \\
\text { less fibre. However, their overall } \\
\text { energy intake was no higher. } \\
\text { Food insecure women had } \\
\text { higher BMIs }\left(2.25 \mathrm{~kg} / \mathrm{m}^{2}\right) \text {, and } \\
\text { around } 15 \% \text { of the BMI } \\
\text { difference between food-insecure } \\
\text { and food-secure women was } \\
\text { accounted for by their more } \\
\text { variable time gaps between } \\
\text { eating, their lower diversity of } \\
\text { foods, and their lower fibre } \\
\text { consumption. }\end{array}$ \\
\hline $\begin{array}{l}\text { Examining the } \\
\text { Association } \\
\text { between Food } \\
\text { Literacy and Food } \\
\text { Insecurity }\end{array}$ & $\begin{array}{c}\text { Andrea Begley; } \\
\text { Ellen Paynter; } \\
\text { Lucy M. Butcher; } \\
\text { Satvinder S. } \\
\text { Dhaliwal } \\
\text { [50] }\end{array}$ & 2019 & Nutrients & $\begin{array}{c}\text { Ad hoc } \\
\text { single } \\
\text { item FI } \\
\text { measure } \\
\text { ENEP }\end{array}$ & Australia & $\begin{array}{l}\text { The aim of this research } \\
\text { was to describe the } \\
\text { apparent prevalence of } \\
\text { food insecurity in adults } \\
\text { at enrolment in a food } \\
\text { literacy program and to } \\
\text { examine the relationship } \\
\text { between food insecurity } \\
\text { and a range of } \\
\text { independent variables. }\end{array}$ & Individuals & $\begin{array}{l}\text { Individuals were } \\
\text { encouraged where } \\
\text { possible to } \\
\text { complete a } \\
\text { questionnaire } \\
\text { before starting the } \\
\text { first session }\end{array}$ & $\begin{array}{l}\text { The results are salient as they } \\
\text { indicate an association between } \\
\text { food literacy and food insecurity. } \\
\text { The implications are that food } \\
\text { insecure participants may } \\
\text { respond differently to food } \\
\text { literacy programs. It may be } \\
\text { necessary to screen people } \\
\text { enrolling in programs, tailor } \\
\text { program content, and include } \\
\text { comprehensive measures in } \\
\text { evaluation to determine effect on } \\
\text { the impact of food literacy } \\
\text { programs on different subgroups }\end{array}$ \\
\hline
\end{tabular}


Table 1. Cont

\begin{tabular}{|c|c|c|c|c|c|c|c|c|c|}
\hline Title & Author/s & Year & Journal & $\begin{array}{c}\text { FI } \\
\text { Measure }\end{array}$ & Country & Objective & $\begin{array}{l}\text { Households/ } \\
\text { Individuals }\end{array}$ & $\begin{array}{l}\text { Data Collection } \\
\text { Procedure }\end{array}$ & Results \\
\hline $\begin{array}{l}\text { Money speaks: } \\
\text { Reductions in } \\
\text { severe food } \\
\text { insecurity follow } \\
\text { the Canada Child } \\
\text { Benefit }\end{array}$ & $\begin{array}{c}\text { Brown, E.M.; } \\
\text { Tarasuk, V. } \\
\text { [65] }\end{array}$ & 2019 & $\begin{array}{l}\text { Preventive } \\
\text { Medicine }\end{array}$ & $\begin{array}{l}\text { 18-item } \\
\text { HFSSM }\end{array}$ & Canada & $\begin{array}{l}\text { To assess whether } \\
\text { Canadian households } \\
\text { with children } \\
\text { experienced reductions } \\
\text { in food insecurity } \\
\text { compared to those } \\
\text { without following the } \\
\text { roll-out of a new } \\
\text { country-wide income } \\
\text { transfer program: the } \\
\text { Canada Child Benefit } \\
\text { (CCB). }\end{array}$ & $\begin{array}{l}\text { Households } \\
\text { (adults and } \\
\text { children) }\end{array}$ & NA & $\begin{array}{l}\text { Multinomial logistic regressions } \\
\text { were used to test the association } \\
\text { between CCB and food } \\
\text { insecurity among three samples: } \\
\text { households reporting any } \\
\text { income ( } n=41,455) \text {, the median } \\
\text { income or less ( } n=18,191) \text { and } \\
\text { the Low-Income Measure (LIM) } \\
\text { or less }(n=7579) \text {. The prevalence } \\
\text { and severity of food insecurity } \\
\text { increased with economic } \\
\text { vulnerability, and were both } \\
\text { consistently higher among } \\
\text { households with children. } \\
\text { However, they also experienced } \\
\text { significantly greater drops in the } \\
\text { likelihood of experiencing severe } \\
\text { food insecurity following CCB; } \\
\text { most dramatically among those } \\
\text { reporting the LIM or less (DID: } \\
\text {-4.7\%, } 95 \% \text { CI: }-8.6,-0.7) \text {. } \\
\text { These results suggest that CCB } \\
\text { disproportionately benefited } \\
\text { families most susceptible to food } \\
\text { insecurity. Furthermore, our } \\
\text { findings also indicate that food } \\
\text { insecurity may be impacted by } \\
\text { even modest changes to } \\
\text { economic circumstance, speaking } \\
\text { to the potential of income } \\
\text { transfers to help people meet } \\
\text { their basic needs. }\end{array}$ \\
\hline
\end{tabular}


Table 1. Cont.

\begin{tabular}{|c|c|c|c|c|c|c|c|c|c|}
\hline Title & Author/s & Year & Journal & $\begin{array}{c}\text { FI } \\
\text { Measure }\end{array}$ & Country & Objective & $\begin{array}{l}\text { Households/ } \\
\text { Individuals }\end{array}$ & $\begin{array}{c}\text { Data Collection } \\
\text { Procedure }\end{array}$ & Results \\
\hline $\begin{array}{l}\text { Impact of fruits } \\
\text { and vegetables } \\
\text { vouchers on food } \\
\text { insecurity in } \\
\text { disadvantaged } \\
\text { families from a } \\
\text { Paris suburb }\end{array}$ & $\begin{array}{l}\text { Buscail, C.; } \\
\text { Gendreau, J.; } \\
\text { Daval, P.; } \\
\text { Lombrail, P.; } \\
\text { Hercberg, S.; } \\
\text { Latino-Martel, P.; } \\
\text { Julia, C. [55] }\end{array}$ & 2019 & BMC Nutrition & $\begin{array}{l}\text { 18-item } \\
\text { HFSSM }\end{array}$ & France & $\begin{array}{l}\text { To assess the impact of } \\
\text { fruits and vegetables } \\
\text { vouchers on food } \\
\text { security among } \\
\text { disadvantaged } \\
\text { households from a Paris } \\
\text { suburb. }\end{array}$ & Households & $\begin{array}{l}\text { Face-to-face at } \\
\text { community } \\
\text { centers or at home }\end{array}$ & $\begin{array}{c}\text { Among the } 91 \text { families included } \\
\text { between May } 2015 \text { and May } 2016, \\
64 \text { completed the post } \\
\text { assessment questionnaire. At } \\
\text { inclusion, } 68.3 \% \text { of families were } \\
\text { experiencing food insecurity and } \\
78.1 \% \text { were experiencing food } \\
\text { insufficiency. No association was } \\
\text { found between food } \\
\text { consumptions and food security } \\
\text { status. After one-year follow-up, } \\
\text { the prevalence of food } \\
\text { insufficiency was significantly } \\
\text { decreased in the intervention } \\
\text { group (61.8\%, with } \\
p \text { value }=0.03) \text {, } \\
\text { and unchanged in the control } \\
\text { group. Conclusion: In this pilot } \\
\text { study, food insufficiency was } \\
\text { significantly decreased in } \\
\text { families receiving vouchers for } \\
\text { fruits and vegetables over a } \\
\text { one-year period }\end{array}$ \\
\hline $\begin{array}{l}\text { Food Insecurity Is } \\
\text { More Strongly } \\
\text { Associated with } \\
\text { Poor Subjective } \\
\text { Well-Being in } \\
\text { More-Developed } \\
\text { Countries than in } \\
\text { Less-Developed } \\
\text { Countries }\end{array}$ & $\begin{array}{c}\text { Frongillo, E.A. } \\
\text { Edward A.; } \\
\text { Nguyen, H.T. Hoa } \\
\text { T.; Smith, M.D. } \\
\text { Michael D. M.D. } \\
\text { Michael D; } \\
\text { Coleman-Jensen, } \\
\text { Alisha } \\
\text { [62] }\end{array}$ & 2019 & $\begin{array}{l}\text { Journal of } \\
\text { Nutrition }\end{array}$ & FIES & $\begin{array}{l}\text { Data from the } \\
\text { Gallup World Poll } \\
2014 \text { in } 147 \text { countries }\end{array}$ & $\begin{array}{l}\text { We aimed to deepen } \\
\text { understanding of the } \\
\text { relation between food } \\
\text { insecurity and subjective } \\
\text { well-being among } \\
\text { countries from the } \\
\text { perspective of possible } \\
\text { hedonic adaptation } \\
\text { between food insecurity } \\
\text { and subjective } \\
\text { well-being }\end{array}$ & Individuals & Gallup survey & $\begin{array}{l}\text { The prevalence of food insecurity } \\
\text { was strongly and negatively } \\
\text { associated with subjective } \\
\text { well-being across } 147 \text { countries. } \\
\text { The association between food } \\
\text { insecurity and poor subjective } \\
\text { well-being within countries was } \\
\text { stronger for more-developed } \\
\text { countries, providing evidence of } \\
\text { hedonic adaptation between } \\
\text { food insecurity and subjective } \\
\text { well-being. Food insecurity } \\
\text { explained substantial variation in } \\
\text { subjective well-being both } \\
\text { among and within countries }\end{array}$ \\
\hline
\end{tabular}


Table 1. Cont.

\begin{tabular}{|c|c|c|c|c|c|c|c|c|c|}
\hline Title & Author/s & Year & Journal & $\begin{array}{c}\text { FI } \\
\text { Measure }\end{array}$ & Country & Objective & $\begin{array}{l}\text { Households/ } \\
\text { Individuals }\end{array}$ & $\begin{array}{l}\text { Data Collection } \\
\text { Procedure }\end{array}$ & Results \\
\hline $\begin{array}{l}\text { Food insecurity } \\
\text { status and } \\
\text { mortality among } \\
\text { adults in Ontario, } \\
\text { Canada }\end{array}$ & $\begin{array}{c}\text { Craig Gundersen, } \\
\text { Valerie Tarasuk, } \\
\text { Joyce Cheng, } \\
\text { Claire de Oliveira, } \\
\text { Paul Kurdyak } \\
\text { [53] }\end{array}$ & 2018 & Plos One & $\begin{array}{l}\text { 18-item } \\
\text { HFSSM }\end{array}$ & Canada & $\begin{array}{l}\text { to ascertain the } \\
\text { association between } \\
\text { food insecurity and } \\
\text { all-cause mortality for a } \\
\text { population-based } \\
\text { sample of adults. }\end{array}$ & Household & NA & $\begin{array}{l}\text { Using a full set of covariates, in } \\
\text { comparison to food secure } \\
\text { individuals, the odds of death at } \\
\text { any point after the interview are } \\
1.28(\mathrm{CI}=1.08,1.52) \text { for } \\
\text { marginally food insecure } \\
\text { individuals, } 1.49(\mathrm{CI}=1.29,1.73) \\
\text { for moderately food insecure } \\
\text { individuals, and } 2.60 \\
(\mathrm{CI}=2.17,3.12) \text { for severely food } \\
\text { insecure individuals. When } \\
\text { mortality within four years of the } \\
\text { interview is considered, the odds } \\
\text { are, respectively, } 1.19 \\
(\mathrm{CI}=0.95,1.50), 1.65 \\
(\mathrm{CI}=1.37,1.98), \text { and } 2.31 \\
(\mathrm{CI}=1.81,2.93)\end{array}$ \\
\hline $\begin{array}{l}\text { Testing the price } \\
\text { of healthy and } \\
\text { current diets in } \\
\text { remote aboriginal } \\
\text { communities to } \\
\text { improve food } \\
\text { security: } \\
\text { Development of } \\
\text { the aboriginal and } \\
\text { torres strait } \\
\text { islander healthy } \\
\text { diets ASAP } \\
\text { (Australian } \\
\text { standardised } \\
\text { affordability and } \\
\text { pricing) methods }\end{array}$ & $\begin{array}{c}\text { Amanda Lee and } \\
\text { Meron Lewis } \\
\text { [51] }\end{array}$ & 2018 & $\begin{array}{l}\text { International } \\
\text { Journal of } \\
\text { Environmental } \\
\text { Research and } \\
\text { Public Health }\end{array}$ & $\begin{array}{l}\text { Healthy } \\
\text { Diets } \\
\text { ASAP }\end{array}$ & Australia & $\begin{array}{l}\text { The aim of this study } \\
\text { was to modify and test } \\
\text { the Healthy Diets ASAP } \\
\text { methods protocol to be } \\
\text { more relevant to the } \\
\text { Aboriginal and Torres } \\
\text { Strait Islander } \\
\text { population. It developed } \\
\text { methods and tools to } \\
\text { assist others to apply the } \\
\text { approach in order to } \\
\text { compare the price, price } \\
\text { differential and } \\
\text { affordability of healthy } \\
\text { (recommended) and } \\
\text { current (unhealthy) diets } \\
\text { of Aboriginal and Torres } \\
\text { Strait Islanders living in } \\
\text { different locations with } \\
\text { other population groups } \\
\text { in Australia. }\end{array}$ & Household & $\begin{array}{l}\text { Face-to-face } \\
\text { interviews }\end{array}$ & \\
\hline
\end{tabular}


Table 1. Cont.

\begin{tabular}{|c|c|c|c|c|c|c|c|c|c|}
\hline Title & Author/s & Year & Journal & FI Measure & Country & Objective & $\begin{array}{l}\text { Households/ } \\
\text { Individuals }\end{array}$ & $\begin{array}{l}\text { Data Collection } \\
\text { Procedure }\end{array}$ & Results \\
\hline $\begin{array}{l}\text { The rise of food } \\
\text { banks and the } \\
\text { challenge of } \\
\text { matching food } \\
\text { assistance with } \\
\text { potential need: } \\
\text { Towards a } \\
\text { spatially specific, } \\
\text { rapid assessment } \\
\text { approach. }\end{array}$ & $\begin{array}{c}\text { Christopher M. } \\
\text { Bacon and } \\
\text { Gregory A. Baker } \\
\text { [49] }\end{array}$ & 2017 & $\begin{array}{l}\text { Agriculture and } \\
\text { Human Values }\end{array}$ & $\begin{array}{c}\text { Food } \\
\text { Insecurity } \\
\text { Index (FII) }\end{array}$ & USA & $\begin{array}{l}\text { The objective of this } \\
\text { study is to assess how } \\
\text { well a local food } \\
\text { assistance organization } \\
\text { serves its clientele from a } \\
\text { geo- graphical } \\
\text { perspective. Specifically, } \\
\text { the research question is: } \\
\text { do the areas with the } \\
\text { highest concentration of } \\
\text { people who are likely in } \\
\text { need of food assistance } \\
\text { have food distribution } \\
\text { sites in close proximity? }\end{array}$ & Households & $\begin{array}{l}\text { Household data } \\
\text { from US Census } \\
\text { ACS 5-year } \\
\text { estimates of } \\
\text { poverty and } \\
\text { demographic data } \\
\text { and data from a } \\
\text { local food bank }\end{array}$ & $\begin{array}{l}\text { The findings suggest that food } \\
\text { assistance distribution locations } \\
\text { match the areas of potential need } \\
\text { in more than } 80 \% \text { of urban } \\
\text { census tracts. However, there are } \\
\text { several potentially underserved } \\
\text { locations and populations that } \\
\text { could benefit from new food } \\
\text { assistance operations. }\end{array}$ \\
\hline $\begin{array}{l}\text { Did food } \\
\text { insecurity rise } \\
\text { across Europe } \\
\text { after the } 2008 \\
\text { crisis? An analysis } \\
\text { across welfare } \\
\text { regimes }\end{array}$ & $\begin{array}{c}\text { Davis, Owen; } \\
\text { Geiger, Ben } \\
\text { Baumberg } \\
\text { [43] }\end{array}$ & 2017 & $\begin{array}{l}\text { Social Policy and } \\
\text { Society }\end{array}$ & $\begin{array}{c}\text { European } \\
\text { Quality of } \\
\text { Life Survey } \\
\text { item 'could } \\
\text { your } \\
\text { household } \\
\text { afford a } \\
\text { meal with } \\
\text { meat, } \\
\text { chicken or } \\
\text { fish every } \\
\text { second day } \\
\text { if you } \\
\text { wanted it?' }\end{array}$ & Europe & $\begin{array}{l}\text { First, we explore } \\
\text { whether food insecurity } \\
\text { has risen since the } 2008 \\
\text { crisis as the rise in food } \\
\text { aid suggests. Second, we } \\
\text { examine if this rise has } \\
\text { varied across welfare } \\
\text { regimes, if it has } \\
\text { occurred at all. }\end{array}$ & Household & $\begin{array}{l}\text { interviews were } \\
\text { conducted } \\
\text { face-to-face in } \\
\text { respondents' own } \\
\text { homes using } \\
\text { standardised } \\
\text { question wording. }\end{array}$ & $\begin{array}{l}\text { The article finds evidence to } \\
\text { support both contentions: food } \\
\text { insecurity has risen across many } \\
\text { European countries and has } \\
\text { varied by welfare regime. It also } \\
\text { finds that contrary to } \\
\text { expectations, the sharpest rise } \\
\text { was in the } \\
\text { Anglo-Saxon countries of Ireland } \\
\text { and the UK, rather than Southern } \\
\text { or Eastern European countries. }\end{array}$ \\
\hline
\end{tabular}


Table 1. Cont.

\begin{tabular}{|c|c|c|c|c|c|c|c|c|c|}
\hline Title & Author/s & Year & Journal & $\begin{array}{c}\text { FI } \\
\text { Measure }\end{array}$ & Country & Objective & $\begin{array}{l}\text { Households/ } \\
\text { Individuals }\end{array}$ & $\begin{array}{l}\text { Data Collection } \\
\text { Procedure }\end{array}$ & Results \\
\hline $\begin{array}{l}\text { The impact of } \\
\text { changes in social } \\
\text { policies on } \\
\text { household food } \\
\text { insecurity in } \\
\text { British Columbia, } \\
\text { 2005-2012 }\end{array}$ & $\begin{array}{c}\text { NaLi, Naomi } \\
\text { Dachner, Valerie } \\
\text { Tarasuk } \\
\text { [54] }\end{array}$ & 2016 & $\begin{array}{l}\text { Preventive } \\
\text { Medicine }\end{array}$ & $\begin{array}{l}\text { 18-item } \\
\text { HFSSM }\end{array}$ & Canada & $\begin{array}{l}\text { The primary objectives } \\
\text { of this study were to } \\
\text { describe the socio- } \\
\text { demographic and } \\
\text { temporal patterning of } \\
\text { food insecurity in BC } \\
\text { from } 2005 \text { to } 2012 \text { and } \\
\text { determine whether BC's } \\
\text { increase in social } \\
\text { assistance and } \\
\text { introduction of the RAP } \\
\text { affected food insecurity } \\
\text { among the target groups. } \\
\text { A secondary objective } \\
\text { was to compare the } \\
\text { sensitivity of different } \\
\text { levels of household food } \\
\text { insecurity to these two } \\
\text { policy interventions. }\end{array}$ & Households & NA & $\begin{array}{l}\text { Overall food insecurity rose } \\
\text { significantly among households } \\
\text { in BC between } 2005 \text { and } 2012 . \\
\text { Following the increase in social } \\
\text { assistance benefits, overall food } \\
\text { insecurity and moderate and } \\
\text { severe food insecurity declined } \\
\text { among households on social } \\
\text { assistance, but severe food } \\
\text { insecurity remained unchanged. }\end{array}$ \\
\hline
\end{tabular}


Table 1. Cont.

\begin{tabular}{|c|c|c|c|c|c|c|c|c|c|}
\hline Title & Author/s & Year & Journal & $\begin{array}{c}\text { FI } \\
\text { Measure }\end{array}$ & Country & Objective & $\begin{array}{l}\text { Households/ } \\
\text { Individuals }\end{array}$ & $\begin{array}{l}\text { Data Collection } \\
\text { Procedure }\end{array}$ & Results \\
\hline $\begin{array}{l}\text { Understanding } \\
\text { Food Insecurity in } \\
\text { the USA } \\
\text { and Canada: } \\
\text { Potential Insights } \\
\text { for Europe }\end{array}$ & $\begin{array}{c}\text { Gundersen, } \mathrm{C} \text {. } \\
\text { [45] }\end{array}$ & 2016 & $\begin{array}{c}\text { World Rev Nutr } \\
\text { Diet. }\end{array}$ & $\begin{array}{l}\text { 18-item } \\
\text { HFSSM }\end{array}$ & US/Canada & $\begin{array}{l}\text { Given the similarities } \\
\text { between the USA, } \\
\text { Canada, and Europe, } \\
\text { previous research can } \\
\text { offer numerous insights } \\
\text { into the causes and } \\
\text { consequences of food } \\
\text { insecurity in Europe and } \\
\text { possible directions to } \\
\text { address these through } \\
\text { measurement and public } \\
\text { policies. }\end{array}$ & Households & NA & $\begin{array}{l}\text { It first covers the methods used } \\
\text { to measure food insecurity in the } \\
\text { USA and Canada. In both } \\
\text { countries, a series of } 18 \text { questions } \\
\text { in the Core Food Security } \\
\text { Module are used to identify } \\
\text { whether a household is food } \\
\text { insecure. It then briefly covers } \\
\text { the current extent of food } \\
\text { insecurity in each country along } \\
\text { with some discussion of the } \\
\text { recent history of food insecurity. } \\
\text { A central advantage to using the } \\
\text { Core Food Security Module in } \\
\text { Europe is that the measure has } \\
\text { been proven useful in other } \\
\text { high-income countries, and } \\
\text { using a standardized measure } \\
\text { would allow for cross-country } \\
\text { comparisons. I next cover two } \\
\text { large-scale food assistance } \\
\text { programs from the USA, the } \\
\text { Supplemental Nutrition } \\
\text { Assistance Program (formerly } \\
\text { known as the Food Stamp } \\
\text { Program) and the National } \\
\text { School Lunch Program. For each, } \\
\text { I summarize how the program is } \\
\text { structured, how eligibility is } \\
\text { established, and how } \\
\text { participation proceeds. Europe } \\
\text { has generally used income-based } \\
\text { assistance programs to improve } \\
\text { the well-being of low-income } \\
\text { households; I consider a couple } \\
\text { of reasons for why food } \\
\text { assistance programs may also be } \\
\text { worth considering. }\end{array}$ \\
\hline
\end{tabular}


Table 1. Cont.

\begin{tabular}{|c|c|c|c|c|c|c|c|c|c|}
\hline Title & Author/s & Year & Journal & FI Measure & Country & Objective & $\begin{array}{l}\text { Households/ } \\
\text { Individuals }\end{array}$ & $\begin{array}{l}\text { Data Collection } \\
\text { Procedure }\end{array}$ & Results \\
\hline $\begin{array}{l}\text { Time and regional } \\
\text { perspectives of } \\
\text { food insecurity } \\
\text { during the } \\
\text { economic crisis in } \\
\text { Portugal, } \\
\text { 2011-2013 }\end{array}$ & $\begin{array}{c}\text { Graca, P.; } \\
\text { Gregorio, M.J.; } \\
\text { Costa, A.; } \\
\text { Nogueira, P.J. } \\
\text { [36] }\end{array}$ & 2014 & $\begin{array}{l}\text { Saúde Soc. São } \\
\text { Paulo, }\end{array}$ & $\begin{array}{l}\text { FI was } \\
\text { assessed } \\
\text { using a psy- } \\
\text { chometric } \\
\text { scale } \\
\text { adapted } \\
\text { from the } \\
\text { Brazilian } \\
\text { Food } \\
\text { Insecurity } \\
\text { Scale (IBGE, } \\
\text { 2010) }\end{array}$ & Portugal & $\begin{array}{l}\text { This study aims to } \\
\text { evaluate trends in FI } \\
\text { prevalence during the } \\
\text { economic crisis in } \\
\text { Portugal and to identify } \\
\text { regional disparities } \\
\text { throughout the country }\end{array}$ & Household & $\begin{array}{l}\text { Data were } \\
\text { collected using } \\
\text { face-to-face } \\
\text { interviews by } \\
\text { nurses in primary } \\
\text { health care }\end{array}$ & $\begin{array}{l}\text { The prevalence of FI was } \\
\text { relatively unchanged at national } \\
\text { and regional levels, during the } \\
\text { analysis period. Data from } 2013 \\
\text { indicates a high prevalence of FI } \\
\text { (50.7\%), including } 33.4 \% \text { for low } \\
\text { FI, } 10.1 \% \text { for moderate FI and } \\
7.2 \% \text { for severe FI. Disparities } \\
\text { according health region were } \\
\text { also found for household FI. } \\
\text { Algarve, Lisbon and Vale do Tejo } \\
\text { were the two regions with the } \\
\text { highest levels of FI, even after } \\
\text { controlling or other } \\
\text { socioeconomic variables. High } \\
\text { levels of FI found in Portugal } \\
\text { and the different regional } \\
\text { profiles suggest the need for } \\
\text { regional strategies, in particular } \\
\text { in the most affected regions } \\
\text { based on a broader action with } \\
\text { different policy sectors (health, } \\
\text { social security, municipalities } \\
\text { and local institutions in the field } \\
\text { of social economy). }\end{array}$ \\
\hline $\begin{array}{l}\text { Stress and Poverty } \\
\text { Predictors of } \\
\text { Treatment } \\
\text { Adherence } \\
\text { Among People } \\
\text { With Low-Literacy } \\
\text { Living With } \\
\text { HIV / AIDS }\end{array}$ & $\begin{array}{c}\text { Kalichman, Seth C } \\
\text { and Grebler, } \\
\text { Tamar } \\
\text { [35] }\end{array}$ & 2010 & $\begin{array}{l}\text { Psychosomatic } \\
\text { Medicine }\end{array}$ & $\begin{array}{l}\text { 6-item } \\
\text { HFSSM }\end{array}$ & USA & $\begin{array}{c}\text { To examine the } \\
\text { association of social, } \\
\text { health, and } \\
\text { poverty-related stressors } \\
\text { in relation to } \\
\text { antiretroviral therapy } \\
\text { adherence in a sample of } \\
\text { people with low-literacy } \\
\text { living with HIV / AIDS } \\
\text { in the South-Eastern } \\
\text { United States. Emotional } \\
\text { distress is among the } \\
\text { more common factors } \\
\text { associated with HIV } \\
\text { treatment adherence. }\end{array}$ & Individuals & $\begin{array}{c}\text { Face-to-face } \\
\text { interviews }\end{array}$ & $\begin{array}{l}\text { Two-thirds of the sample } \\
\text { demonstrated adherence }<85 \% \text { of } \\
\text { pills taken. Multivariable } \\
\text { analyses showed that food } \\
\text { insufficiency and hunger } \\
\text { predicted antiretroviral therapy } \\
\text { nonadherence over and above } \\
\text { depression, internalized stigma, } \\
\text { substance use, and HIV-related } \\
\text { social stressors }\end{array}$ \\
\hline
\end{tabular}


Table 1. Cont

\begin{tabular}{|c|c|c|c|c|c|c|c|c|c|}
\hline Title & Author/s & Year & Journal & $\begin{array}{c}\text { FI } \\
\text { Measure }\end{array}$ & Country & Objective & $\begin{array}{l}\text { Households/ } \\
\text { Individuals }\end{array}$ & $\begin{array}{c}\text { Data Collection } \\
\text { Procedure }\end{array}$ & Results \\
\hline $\begin{array}{l}\text { Food insecurity } \\
\text { and aging during } \\
\text { economic crisis }\end{array}$ & $\begin{array}{c}\text { Graça, P., } \\
\text { Gregoório, M.J. } \\
\text { [52] }\end{array}$ & 2017 & $\begin{array}{l}\text { Psychology and } \\
\text { Behavior }\end{array}$ & $\begin{array}{l}\text { Brazilian } \\
\text { Food } \\
\text { Insecurity } \\
\text { Scale }\end{array}$ & Portugal & $\begin{array}{l}\text { To assess food insecurity } \\
\text { prevalence across age } \\
\text { groups in Portugal. }\end{array}$ & Households & $\begin{array}{l}\text { Face-to-face } \\
\text { interviews }\end{array}$ & $\begin{array}{l}\text { This national survey on food } \\
\text { insecurity, implemented in } 2011 \\
\text { in order to evaluate food } \\
\text { insecurity trends during the } \\
\text { period that Portugal was under } \\
\text { the International Monetary Fund } \\
\text { financial assistance program } \\
\text { (2011-2014), found a high } \\
\text { prevalence of food in- security in } \\
\text { the Portuguese population. In } \\
\text { 2014, } 45.8 \% \text { of the Portuguese } \\
\text { households included in this } \\
\text { study were food insecure. A } \\
\text { higher risk of food insecurity } \\
\text { was observed in the age groups } \\
\text { of } 30-64 \text { years, when comparing } \\
\text { to adults aged } 65 \text { and over. Data } \\
\text { from Infofamiilia survey in } \\
\text { Portugal are consistent with } \\
\text { results obtained in other } \\
\text { countries. }\end{array}$ \\
\hline
\end{tabular}


Table 1. Cont

\begin{tabular}{|c|c|c|c|c|c|c|c|c|c|}
\hline Title & Author/s & Year & Journal & FI Measure & Country & Objective & $\begin{array}{l}\text { Households/ } \\
\text { Individuals }\end{array}$ & $\begin{array}{l}\text { Data Collection } \\
\text { Procedure }\end{array}$ & Results \\
\hline $\begin{array}{l}\text { Food insecurity } \\
\text { and mental health } \\
\text { among females in } \\
\text { high-income } \\
\text { countries }\end{array}$ & $\begin{array}{c}\text { Merryn Maynard, } \\
\text { Lesley Andrade, } \\
\text { Sara Packull- } \\
\text { McCormick, } \\
\text { Christopher M. } \\
\text { Perlman, Cesar } \\
\text { Leos-Toro and } \\
\text { Sharon, I. } \\
\text { Kirkpatrick } \\
\text { [61] }\end{array}$ & 2018 & $\begin{array}{l}\text { International } \\
\text { Journal of } \\
\text { Environmental } \\
\text { Research and } \\
\text { Public Health }\end{array}$ & $\begin{array}{l}\text { 18-item } \\
\text { HFSSM } \\
\text { (USDA); } \\
\text { single-item } \\
\text { from } \\
\text { Radimer } \\
\text { Cornell; } \\
\text { Community } \\
\text { Childhood } \\
\text { Hunger } \\
\text { Identifica- } \\
\text { tion Project } \\
\text { (CCHIP); } \\
\text { single-item } \\
\text { National } \\
\text { Health and } \\
\text { Nutrition } \\
\text { Examina- } \\
\text { tion Survey } \\
\text { (NHANES- } \\
\text { III); New } \\
\text { Zealand } \\
\text { measure of } \\
\text { individual } \\
\text { deprivation, } \\
\text { Other multi } \\
\text { or single } \\
\text { item } \\
\text { measures }\end{array}$ & $\begin{array}{l}\text { USA, Canada, } \\
\text { New Zealand and } \\
\text { England }\end{array}$ & $\begin{array}{l}\text { to examine the state of } \\
\text { the literature on food } \\
\text { insecurity and mental } \\
\text { health among women } \\
\text { living in high-income } \\
\text { countries }\end{array}$ & $\begin{array}{l}\text { Individuals } \\
\text { (women) }\end{array}$ & N/A & $\begin{array}{l}\text { Most research was } \\
\text { cross-sectional and showed } \\
\text { associations between depression } \\
\text { and food insecurity; longitudinal } \\
\text { analyses suggested bidirectional } \\
\text { relationships (with food } \\
\text { insecurity increasing the risk of } \\
\text { depressive symptoms or } \\
\text { diagnosis, or depression } \\
\text { predicting food insecurity). } \\
\text { Several articles focused on } \\
\text { vulnerable subgroups, such as } \\
\text { pregnant women and mothers, } \\
\text { women at risk of homelessness, } \\
\text { refugees, and those who had } \\
\text { been exposed to violence or } \\
\text { substance abuse. Overall, this } \\
\text { review supports a link between } \\
\text { food insecurity and mental } \\
\text { health (and other factors, such as } \\
\text { housing circumstances and } \\
\text { exposure to violence) among } \\
\text { women in high-income countries } \\
\text { and underscores the need for } \\
\text { comprehensive policies and } \\
\text { programs that recognize complex } \\
\text { links among public health } \\
\text { challenges. }\end{array}$ \\
\hline
\end{tabular}


Table 1. Cont.

\begin{tabular}{|c|c|c|c|c|c|c|c|c|c|}
\hline Title & Author/s & Year & Journal & $\begin{array}{c}\text { FI } \\
\text { Measure }\end{array}$ & Country & Objective & $\begin{array}{l}\text { Households/ } \\
\text { Individuals }\end{array}$ & $\begin{array}{l}\text { Data Collection } \\
\text { Procedure }\end{array}$ & Results \\
\hline $\begin{array}{l}\text { Place and food } \\
\text { insecurity: A } \\
\text { critical review and } \\
\text { synthesis of the } \\
\text { literature }\end{array}$ & $\begin{array}{c}\text { Megan Ann Carter, } \\
\text { Lise Dubois and } \\
\text { Mark S Tremblay } \\
\text { [64] }\end{array}$ & 2014 & $\begin{array}{l}\text { Public Health } \\
\text { Nutrition }\end{array}$ & $\begin{array}{l}\text { 18-item } \\
\text { HFSSM; } \\
\text { 6-item } \\
\text { HFSSM; } \\
\text { Commu- } \\
\text { nity } \\
\text { Child- } \\
\text { hood } \\
\text { Hunger } \\
\text { Identifica- } \\
\text { tion } \\
\text { Project; } \\
\text { Radimer } \\
\text { Cornell } \\
\text { measure; } \\
\text { adapted } \\
\text { version of } \\
\text { Radimer } \\
\text { Cornell } \\
\text { measure }\end{array}$ & $\begin{array}{c}\text { N/A(systematic } \\
\text { review) }\end{array}$ & $\begin{array}{l}\text { The present review } \\
\text { sought to synthesize and } \\
\text { critically appraise the } \\
\text { existing literature } \\
\text { examining local } \\
\text { environmental } \\
\text { characteristics in relation } \\
\text { to } \\
\text { individual/household- } \\
\text { level food insecurity in } \\
\text { the general population. }\end{array}$ & $\begin{array}{l}\text { Households } \\
\text { and } \\
\text { individuals }\end{array}$ & $\begin{array}{l}\text { This review chose } \\
\text { those research } \\
\text { studies for } \\
\text { inclusion if they } \\
\text { examined the } \\
\text { relationship } \\
\text { between features } \\
\text { of place and } \\
\text { self-reported food } \\
\text { insecurity (either } \\
\text { at the } \\
\text { household/family } \\
\text { or individual } \\
\text { level). }\end{array}$ & $\begin{array}{l}\text { After obtaining full-text articles, } \\
\text { eighteen primary studies met the } \\
\text { eligibility criteria. Most studies } \\
\text { were conducted in the USA and } \\
\text { all but one was cross- sectional. } \\
\text { Seven of the eleven studies that } \\
\text { examined location of residence } \\
\text { found that rural living was } \\
\text { inversely associated with food } \\
\text { insecurity. Mixed results were } \\
\text { seen for other place measures } \\
\text { such as social capital and } \\
\text { distance to food stores. } \\
\text { Conclusions: Studies were } \\
\text { heterogeneous and had various } \\
\text { limitations that preclude } \\
\text { definitive conclusions from being } \\
\text { drawn. Recommendations for } \\
\text { future research are provided. }\end{array}$ \\
\hline
\end{tabular}


Table 1. Cont.

\begin{tabular}{|c|c|c|c|c|c|c|c|c|c|}
\hline Title & Author/s & Year & Journal & FI Measure & Country & Objective & $\begin{array}{l}\text { Households/ } \\
\text { Individuals }\end{array}$ & $\begin{array}{c}\text { Data Collection } \\
\text { Procedure }\end{array}$ & Results \\
\hline $\begin{array}{l}\text { Investigating food } \\
\text { insecurity } \\
\text { measurement } \\
\text { globally to inform } \\
\text { practice locally: A } \\
\text { rapid evidence } \\
\text { review }\end{array}$ & $\begin{array}{c}\text { Emma Beacom, } \\
\text { Sineéad Furey, } \\
\text { Lynsey } \\
\text { Hollywood and } \\
\text { Paul Humphreys } \\
\text { [22] }\end{array}$ & 2020 & $\begin{array}{l}\text { Critical Reviews } \\
\text { in Food Science } \\
\text { and Nutrition }\end{array}$ & $\begin{array}{l}\text { 18-item } \\
\text { HFSSM; } \\
\text { 6-item } \\
\text { HFSSM; } \\
\text { FIES; USDA } \\
\text { Food Insuffi- } \\
\text { ciency } \\
\text { Question; } \\
\text { 10-item } \\
\text { AFSSM; } \\
\text { adapted } \\
\text { HFSSM; } \\
\text { Australian } \\
\text { National } \\
\text { Health } \\
\text { Survey } \\
\text { single-item } \\
\text { measure; } \\
\text { Household } \\
\text { Food and } \\
\text { Nutrition } \\
\text { Security } \\
\text { Survey } \\
\text { (HFNSS); } \\
\text { USDA Food } \\
\text { Insecurity } \\
\text { and Hunger } \\
\text { Scale }\end{array}$ & $\begin{array}{c}\text { N/A(systematic } \\
\text { review) }\end{array}$ & $\begin{array}{l}\text { The objective of this } \\
\text { review was to examine } \\
\text { the methods used to } \\
\text { measure food insecurity } \\
\text { (FI) globally, to inform } \\
\text { considerations relating } \\
\text { to adopting a novel, or } \\
\text { reviewing an existing, FI } \\
\text { measurement approach } \\
\text { in developed countries. }\end{array}$ & $\begin{array}{l}\text { Households } \\
\text { and } \\
\text { individuals }\end{array}$ & $\begin{array}{l}\text { Focus groups, } \\
\text { surveys, } \\
\text { secondary data } \\
\text { analysis, and } \\
\text { interviews }\end{array}$ & $\begin{array}{l}\text { Results found that the majority } \\
\text { of papers reviewed emanate } \\
\text { from North America with the US } \\
\text { Household Food Security Scale } \\
\text { Module (HFSSM) and its various } \\
\text { adapted forms being the most } \\
\text { commonly reported indicator. FI } \\
\text { is becoming a key concern within } \\
\text { developed countries with a range } \\
\text { of indicators being used to report } \\
\text { on the severity of the issue. }\end{array}$ \\
\hline
\end{tabular}


Table 1. Cont.

\begin{tabular}{|c|c|c|c|c|c|c|c|c|c|}
\hline Title & Author/s & Year & Journal & FI Measure & Country & Objective & $\begin{array}{l}\text { Households/ } \\
\text { Individuals }\end{array}$ & $\begin{array}{l}\text { Data Collection } \\
\text { Procedure }\end{array}$ & Results \\
\hline $\begin{array}{c}\text { Identifying a } \\
\text { potential tool to } \\
\text { measure } \\
\text { household food } \\
\text { insecurity in the } \\
\text { UK: A systematic } \\
\text { review }\end{array}$ & $\begin{array}{l}\text { G. Nguyen, L. } \\
\text { Aucott, G. } \\
\text { McNeill, F. } \\
\text { Douglas } \\
\text { [21] }\end{array}$ & 2017 & $\begin{array}{l}\text { Proceedings of the } \\
\text { Nutrition Society }\end{array}$ & $\begin{array}{l}\text { Twenty } \\
\text { different tools } \\
\text { were } \\
\text { identified } \\
\text { with the most } \\
\text { commonly } \\
\text { used being the } \\
\text { USDA } \\
\text { Household } \\
\text { Food Security } \\
\text { Survey } \\
\text { Module } \\
\text { (HFSSM) } \\
\text { (66\%), the } \\
\text { Canadian } \\
\text { HFSSM ( } 8 \% \text { ). } \\
\text { Other tools } \\
\text { such as the } \\
\text { Radimer/Cornell } \\
\text { Hunger Scale, } \\
\text { FAO Food } \\
\text { Insecurity } \\
\text { Experience } \\
\text { Scale (FIES), } \\
\text { etc. had only } \\
\text { been used in a } \\
\text { small } \\
\text { proportion of } \\
\text { the included } \\
\text { studies }\end{array}$ & 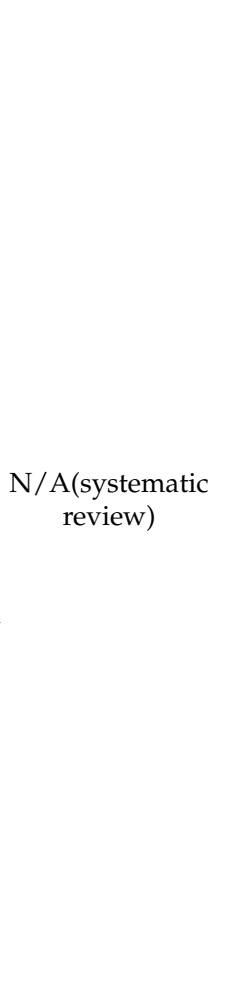 & $\begin{array}{l}\text { to identify the } \\
\text { measurement } \\
\text { instruments which have } \\
\text { been used to measure } \\
\text { HFI in developed/high } \\
\text { income countries which } \\
\text { would be suitable for } \\
\text { use in the UK context. }\end{array}$ & $\begin{array}{l}\text { Households } \\
\text { and } \\
\text { individuals }\end{array}$ & NA & $\begin{array}{l}\text { There are a number of structured } \\
\text { scales available in the literature } \\
\text { for measuring HFI, the USDA } \\
\text { HFSSM stands out as the most } \\
\text { commonly used tool in high } \\
\text { income countries. Additional } \\
\text { work to develop questions to } \\
\text { better capture the psychological } \\
\text { and social components of HFI is } \\
\text { required. }\end{array}$ \\
\hline
\end{tabular}


Table 1. Cont

\begin{tabular}{|c|c|c|c|c|c|c|c|c|c|}
\hline Title & Author/s & Year & Journal & FI Measure & Country & Objective & $\begin{array}{l}\text { Households/ } \\
\text { Individuals }\end{array}$ & $\begin{array}{l}\text { Data Collection } \\
\text { Procedure }\end{array}$ & Results \\
\hline $\begin{array}{l}\text { Measuring food } \\
\text { insecurity }\end{array}$ & $\begin{array}{c}\text { Castetbon, K. } \\
\text { [16] }\end{array}$ & 2016 & Book chapter & $\begin{array}{l}\text { Radimer/Cornell } \\
\text { Cornell } \\
\text { Child Food } \\
\text { Security } \\
\text { Measure } \\
\text { Community } \\
\text { Childhood } \\
\text { Hunger } \\
\text { Identification } \\
\text { Project } \\
\text { (CCHIP) tool } \\
\text { Food Security } \\
\text { Core Module } \\
\text { (FSCM), also } \\
\text { named US } \\
\text { HFSS }\end{array}$ & $\begin{array}{c}\text { N/A(systematic } \\
\text { review) }\end{array}$ & $\begin{array}{l}\text { reviews studies into } \\
\text { food security at the level } \\
\text { of the household and of } \\
\text { the individual, focusing } \\
\text { especially on the } \\
\text { question of how to } \\
\text { define and measure the } \\
\text { complex concept of food } \\
\text { insecurity. }\end{array}$ & $\begin{array}{l}\text { Households } \\
\text { and } \\
\text { individuals }\end{array}$ & NA & $\begin{array}{c}\text { The concept of 'food security' } \\
\text { has been under discussion since } \\
\text { the 1970s, and an extensive } \\
\text { literature on it has existed since } \\
\text { the early 1990s. } \\
\text { - Research into food insecurity } \\
\text { has focused primarily on the } \\
\text { developing world, but food } \\
\text { insecurity also exists in the } \\
\text { developed world. } \\
\text { Questionnaires designed to } \\
\text { measure food insecurity most } \\
\text { commonly focus on the level of } \\
\text { the individual and of the } \\
\text { household. } \\
\text { - Questionnaires designed to } \\
\text { measure food insecurity have } \\
\text { become progressively more } \\
\text { sophisticated. } \\
\text { - The definition of 'food } \\
\text { insecurity' is still in flux. } \\
\text { - Existing data on food insecurity } \\
\text { are too diverse to admit a simple } \\
\text { synthesis, but further research } \\
\text { will generate findings that will } \\
\text { permit a thoroughgoing analysis } \\
\text { of the phenomenon. }\end{array}$ \\
\hline
\end{tabular}


Table 1. Cont

\begin{tabular}{|c|c|c|c|c|c|c|c|c|c|}
\hline Title & Author/s & Year & Journal & FI Measure & Country & Objective & $\begin{array}{l}\text { Households/ } \\
\text { Individuals }\end{array}$ & $\begin{array}{l}\text { Data Collection } \\
\text { Procedure }\end{array}$ & Results \\
\hline $\begin{array}{l}\text { Measurement of } \\
\text { household food } \\
\text { security in the } \\
\text { USA and other } \\
\text { industrialised } \\
\text { countries }\end{array}$ & $\begin{array}{c}\text { Kathy L. Radimer } \\
\text { [60] }\end{array}$ & 2002 & $\begin{array}{l}\text { Public Health } \\
\text { Nutrition }\end{array}$ & $\begin{array}{c}\text { 18-item } \\
\text { HFSSM } \\
\text { (USDA); } \\
\text { 6-item } \\
\text { HFSSM; } \\
\text { USDA Food } \\
\text { Insufficiency } \\
\text { Indicator; } \\
\text { 8-item Food } \\
\text { Security } \\
\text { Survey (Reid, } \\
\text { New Zealand); } \\
\text { 2-item } \\
\text { adapted from } \\
\text { Radimer } \\
\text { Cornell } \\
\text { (Australia); } \\
\text { National } \\
\text { Population } \\
\text { Health Survey } \\
\text { (Canada) }\end{array}$ & $\begin{array}{c}\text { USA, New } \\
\text { Zealand, } \\
\text { Australia, } \\
\text { Canada }\end{array}$ & $\begin{array}{l}\text { To describe the history } \\
\text { and current status of } \\
\text { household food security } \\
\text { measurement in the USA } \\
\text { and other industrialised } \\
\text { countries. }\end{array}$ & $\begin{array}{l}\text { Households } \\
\text { and } \\
\text { individuals }\end{array}$ & N/A & $\begin{array}{l}\text { Current research on food security } \\
\text { measurement includes } \\
\text { measurement of individual food } \\
\text { insecurity and hunger, module } \\
\text { performance regarding hunger } \\
\text { duration and frequency, } \\
\text { performance of the module in } \\
\text { population sub- groups, and the } \\
\text { effect of translations on module } \\
\text { meaning and performance. } \\
\text { National surveys in Canada, } \\
\text { New Zealand and Australia also } \\
\text { have measured food security. }\end{array}$ \\
\hline
\end{tabular}


Table 1. Cont

\begin{tabular}{|c|c|c|c|c|c|c|c|c|c|}
\hline Title & Author/s & Year & Journal & FI Measure & Country & Objective & $\begin{array}{l}\text { Households/ } \\
\text { Individuals }\end{array}$ & $\begin{array}{l}\text { Data Collection } \\
\text { Procedure }\end{array}$ & Results \\
\hline $\begin{array}{l}\text { Measurement of } \\
\text { the dimensions of } \\
\text { food insecurity in } \\
\text { developed } \\
\text { countries: A } \\
\text { systematic } \\
\text { literature review }\end{array}$ & $\begin{array}{l}\text { Ashby, Stephanie; } \\
\text { Kleve, Suzanne; } \\
\text { McKechnie, } \\
\text { Rebecca; Palermo, } \\
\text { Claire [23] }\end{array}$ & 2016 & $\begin{array}{l}\text { Public Health } \\
\text { Nutrition }\end{array}$ & $\begin{array}{l}\text { Radimer/Corne } \\
\text { Cornell Child } \\
\text { Food Security } \\
\text { Measure } \\
\text { Community } \\
\text { Childhood } \\
\text { Hunger } \\
\text { Identification } \\
\text { Project } \\
\text { (CCHIP) tool } \\
\text { Hager } \\
\text { two-item } \\
\text { screen Girard } \\
\text { four-point } \\
\text { tool Kuyper } \\
\text { part food } \\
\text { insecurity } \\
\text { Household } \\
\text { Food } \\
\text { Insecurity } \\
\text { Access Scal } \\
\text { (HFIAS) } \\
\text { Townsend } \\
\text { Food Behavior } \\
\text { Checklist }\end{array}$ & $\begin{array}{c}\text { N/A(systematic } \\
\text { review) }\end{array}$ & $\begin{array}{l}\text { The aim of the present } \\
\text { study was to conduct a } \\
\text { systematic literature } \\
\text { review to identify all } \\
\text { multi-item tools that } \\
\text { measure food insecurity } \\
\text { and explore which of the } \\
\text { dimensions they assess. }\end{array}$ & $\begin{array}{l}\text { Households } \\
\text { and } \\
\text { individuals }\end{array}$ & NA & $\begin{array}{l}\text { Eight multi-item tools were } \\
\text { identified. All of the tools } \\
\text { assessed the 'food access' } \\
\text { dimension and two partially } \\
\text { assessed the dimensions 'food } \\
\text { utilization' and 'stability over } \\
\text { time', respectively. 'Food } \\
\text { availability' was not assessed by } \\
\text { existing tools. Conclusions: } \\
\text { Current tools available for } \\
\text { measuring food insecurity are } \\
\text { subjective, } \\
\text { limited in scope, with a majority } \\
\text { assessing only one dimension of } \\
\text { food insecurity } \\
\text { (access). To more accurately } \\
\text { assess the true burden of food } \\
\text { insecurity, tools should be } \\
\text { adapted or developed to assess } \\
\text { all four dimensions of food } \\
\text { insecurity }\end{array}$ \\
\hline
\end{tabular}

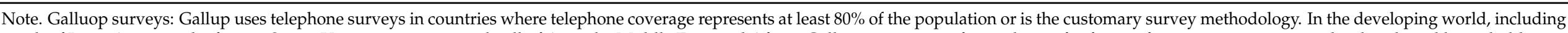

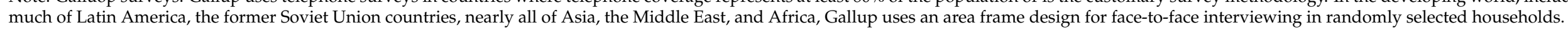




\subsection{Grey Literature}

The grey literature part of the sample is composed by the thesis $(n=73)$, research and institutional reports $(n=36)$, conferences $(n=3)$, book chapters $(n=1)$ and newsletter pieces $(n=1)$. For periodical reports (like the FAO's SOFI), we have only considered the last version. Twenty records were published between 2000 and 2010, but the vast majority $(n=76)$ are posterior to 2015.

With regard to the countries where the data was collected, three of them report data from several countries-some including only developed but most also developing countries $[2,68,69]$ five of them come from Australia [70-74], one from New Zealand [75], five from the UK [76-80], two from Spain [81,82], and 24 from Canada [83-104]. The remaining 73 documents report data from the US [105-173].

Most documents provide data on the prevalence and correlations of food insecurity in the different territories and population groups, although a small sample $(n=4)$ also delves into the effect of interventions $[99,141]$ or policy options [65,94].

Food insecurity was measured at the household level in 49 of the records, being the most used instruments the 18-item HFFSSM $(n=39)$, the 10-item HFSSM $(n=4)$, the 6-item HFSSM $(n=3)$, the single-item food insecurity question from the Australian NSW Population Health Survey $(n=1)$, the FIES scale $(n=2)$, the European Quality of Life Survey item "could your household afford a meal with meat, chicken or fish every second day if you wanted it?" ( $n=1)$; Current Population Survey Food Security Supplement (CPS FSS), USDA $(n=1)$. Note that some of the studies use more than one measurement instrument.

The remaining 67 documents assessed food insecurity at the individual level, with a variety of profiles: three focused on adolescents, and used the 9-item CFSSM $(n=2)$ and the single-item Food Insecurity Measure $(n=1)$. Most records measured food insecurity in adults $(n=31)$, four of them being exclusively on women and used the 6-item and 18-item HFSSM, the 2005 Oregon PRAMS single-item Food Insecurity Measure and the HFIAS Scale. The other studies on adults comprise both gender and measure food insecurity through the 6-item $(n=10), 10$ item $(n=6), 18$-item HFSSM $(n=5)$, the Radimer-Cornell Food Insecurity Measure $(n=1)$, the 8-item food security questionnaire by Reid (1997) $(n=1)$, the single item Food Insecurity measure $(n=1)$, the Food Security Module at the LISA Study $(n=1)$ and the HFIAS scale $(n=1)$. Five additional studies were conducted on adults and children, and used the FIES scale $(n=2), 6$-item HFSSM $(n=1)$ and 18-item $\operatorname{HFSSM}(n=2) ; 23$ on College students, and measured food insecurity through the 6-item $\operatorname{HFSSM}(n=14), 10$ item HFSSM $(n=2)$ and 18-item HFSSM $(n=7)$; and four documents reported measures of food insecurity on elderly, using the 6-item HFSSM $(n=2)$ and 10 -item HFSSM $(n=1)$ and FIES scale $(n=1)$ (see Table 2 ). 
Table 2. Overview of Grey Literature in food insecurity studies, theses, reports, conferences and newsletters.

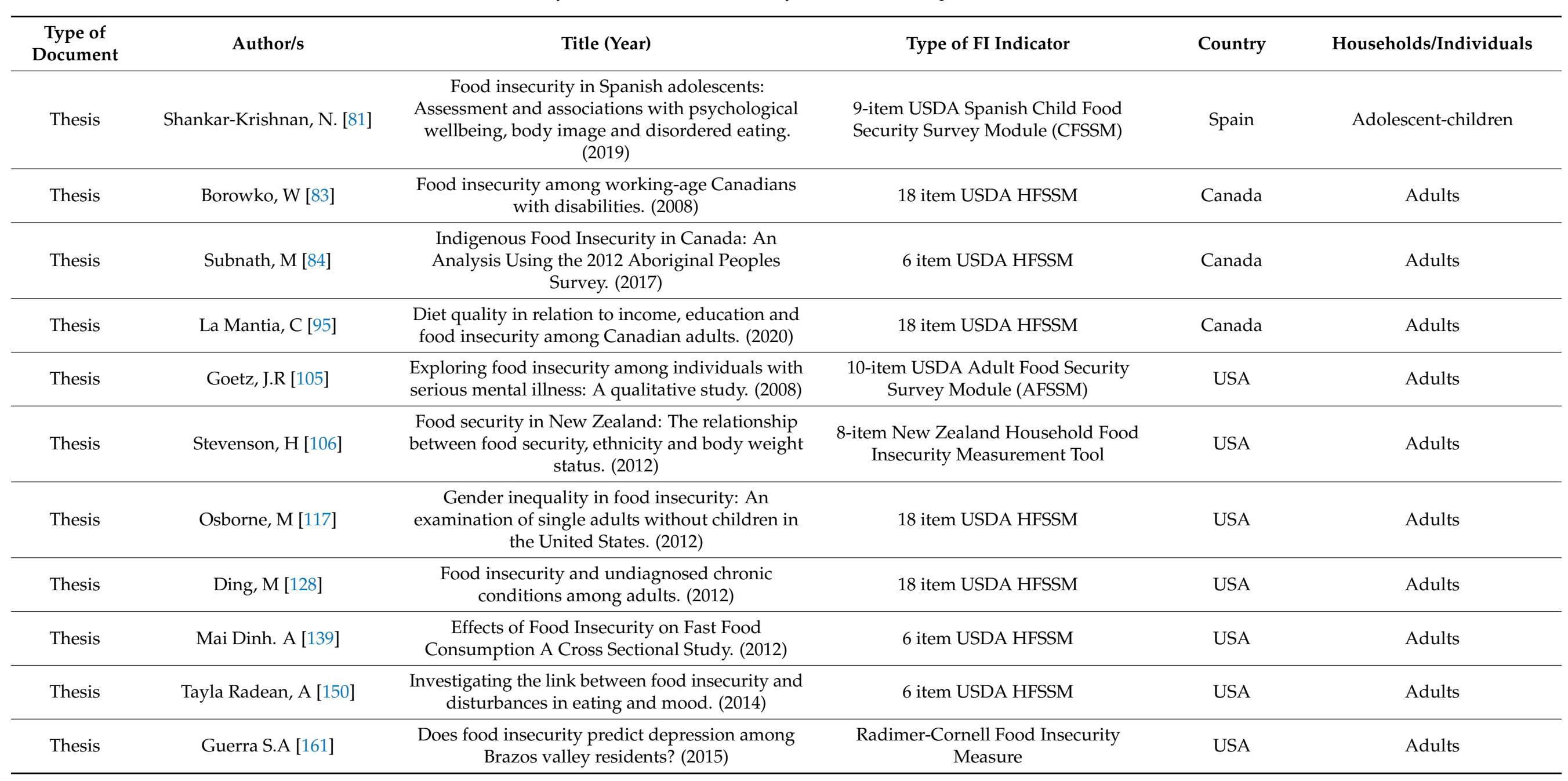


Table 2. Cont.

\begin{tabular}{|c|c|c|c|c|c|}
\hline $\begin{array}{c}\text { Type of } \\
\text { Document }\end{array}$ & Author/s & Title (Year) & Type of FI Indicator & Country & Households/Individuals \\
\hline Thesis & Little TV [174] & $\begin{array}{l}\text { Language Proficiency, Citizenship, and Food Insecurity } \\
\text { among Predominantly Immigrant Caribbean Latinos in } \\
\text { Massachusetts: A Masters Thesis. (2015) }\end{array}$ & 6 item USDA HFSSM & USA & Adults \\
\hline Thesis & Prezzato. E.L [172] & $\begin{array}{l}\text { Dietary intake and risk factors associated with food } \\
\text { insecurity. (2015) }\end{array}$ & 6 item USDA HFSSM & USA & Adults \\
\hline Thesis & Rodriguez. P [173] & $\begin{array}{l}\text { Development of a Food Program Design for the San } \\
\text { Fernando Valley Rescue Mission to Improve Food } \\
\text { Insecurity and Health Among Participants. (2016) }\end{array}$ & 6 item USDA HFSSM & USA & Adults \\
\hline Thesis & Mercado, V [107] & $\begin{array}{l}\text { Food and housing insecurity among students at a } \\
\text { community college district. (2017) }\end{array}$ & 6-item USDA HFSSM & USA & Adults \\
\hline Thesis & Kashuba, K [108] & $\begin{array}{l}\text { The prevelance, correlates, and academic consequences } \\
\text { of food insecurity among University of Oregon Students. } \\
\text { (2017). }\end{array}$ & 6 item USDA HFSSM & USA & Adults \\
\hline Thesis & Eubanks, M M [109] & $\begin{array}{c}\text { The Prevalence of Food Insecurity within the University } \\
\text { of Mississippi Community and Knowledge of and } \\
\text { Opinions About the University of Mississippi Food } \\
\text { Bank. (2017) }\end{array}$ & 6 item USDA HFSSM & USA & Adults \\
\hline Thesis & Harris, E. A & $\begin{array}{l}\text { A socio-ecological analysis of the relationship between } \\
\text { eating pathology and food insecurity (2018) }\end{array}$ & 10 item USDA HFSSM & USA & Adults \\
\hline Thesis & Hagedorn R.L [112] & $\begin{array}{l}\text { WISH4Campus: Evaluating college food insecurity and } \\
\text { promoting solutions for student wellbeing. (2019) }\end{array}$ & 10 item USDA HFSSM & USA & Adults \\
\hline Thesis & Sydnor, M.L [175] & $\begin{array}{l}\text { Feed me, house me: Undergraduate college students' } \\
\text { perspectives on food and housing insecurity. (2019) }\end{array}$ & 6 item USDA HFSSM & USA & Adults \\
\hline Thesis & Goldson, T [114] & $\begin{array}{l}\text { An examination of the impact of the supplemental } \\
\text { nutrition assistance program on food insecurity and } \\
\text { depression among low-income adults living in the } \\
\text { United States (2019) }\end{array}$ & 10 item USDA HFSSM & USA & Adults \\
\hline Thesis & Shirley, T [115] & $\begin{array}{l}\text { Food insecurity and produce behaviors of adults with } \\
\text { children in rural, Appalachian Mississippi. (2019) }\end{array}$ & 10 item USDA HFSSM & USA & Adults \\
\hline
\end{tabular}


Table 2. Cont

\begin{tabular}{|c|c|c|c|c|c|}
\hline $\begin{array}{c}\text { Type of } \\
\text { Document }\end{array}$ & Author/s & Title (Year) & Type of FI Indicator & Country & Households/Individuals \\
\hline Thesis & Pittman, S.E [116] & Exploring Illinois farmers' food insecurity status. (2020) & 18 item USDA HFSSM & USA & Adults \\
\hline Thesis & Raja, A [119] & $\begin{array}{l}\text { Food insecurity and alcohol use in people with HIV } \\
\text { infection and substance use disorder. (2017) }\end{array}$ & HFIAS & USA & Adults \\
\hline Thesis & Loopstra, R [99] & $\begin{array}{l}\text { Household Food Insecurity in Canada: Towards an } \\
\text { Understanding of Effective Interventions. (2014) }\end{array}$ & 18 item USDA HFSSM & Canada & Adults and Children \\
\hline Thesis & Ramsey, R [74] & $\begin{array}{l}\text { Food and Brisbane households-dietary, health and social } \\
\text { consequences of food insecurity. (2011) }\end{array}$ & 18 item USDA HFSSM & Australia & Adults and Children \\
\hline Thesis & Burris, M [120] & $\begin{array}{l}\text { Food insecurity and age of menarche: using a } \\
\text { biocultural approach and life history theory to assess } \\
\text { risks of food insecurity among girls in Tampa Bay, FL. } \\
\text { (2018) }\end{array}$ & 6 item USDA HFSSM & USA & Adults and Children dyads \\
\hline Thesis & Maynard, M [100] & $\begin{array}{c}\text { Experiences of Food Insecurity Among Undergraduate } \\
\text { Students at the University of Waterloo: Barriers, Coping } \\
\text { Strategies, and Perceived Health and Academic } \\
\text { Outcomes (2016) }\end{array}$ & 18 item USDA HFSSM & Canada & College students \\
\hline Thesis & Hattangadi, N [101] & $\begin{array}{l}\text { Do university students who experience food insecurity } \\
\text { report psychological distress? (2018) }\end{array}$ & 6 item USDA HFSSM & Canada & College students \\
\hline Thesis & Maroto. M [122] & $\begin{array}{l}\text { Food insecurity among community college students: } \\
\text { prevalence and relationship to GPA, energy and } \\
\text { concentration. (2013) }\end{array}$ & 10 item USDA HFSSM & USA & College students \\
\hline Thesis & Gorman, A [123] & $\begin{array}{c}\text { Food insecurity prevalence among college students at } \\
\text { Kent State University. (2014) }\end{array}$ & 18 item USDA HFSSM & USA & College students \\
\hline Thesis & MacDonald, A [127] & $\begin{array}{l}\text { Food Insecurity and Educational Attainment at the } \\
\text { University of Arkansas. (2016) }\end{array}$ & 6-item USDA HFSSM & USA & College students \\
\hline Thesis & Camelo, K [130] & $\begin{array}{l}\text { Predictors of food insecurity and their relationship to } \\
\text { academic achievement of college students. (2017). }\end{array}$ & 6 item USDA HFSSM & USA & College students \\
\hline Thesis & Adamovic. E [131] & $\begin{array}{l}\text { Food insecurity among college students: An assessment } \\
\text { of prevalence and solutions. (2017) }\end{array}$ & 6 item USDA HFSSM & USA & College students \\
\hline
\end{tabular}


Table 2. Cont.

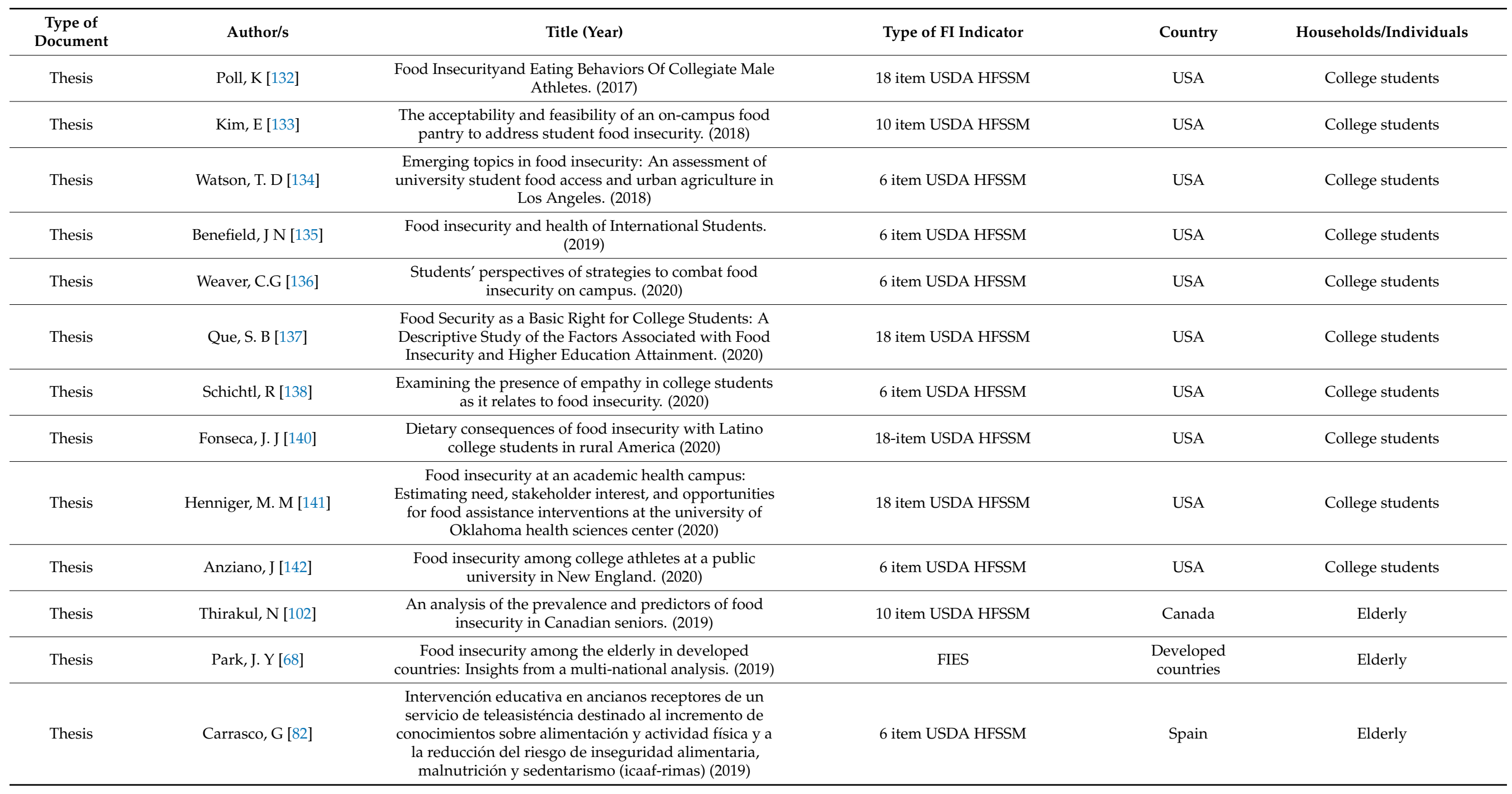


Table 2. Cont.

\begin{tabular}{|c|c|c|c|c|c|}
\hline $\begin{array}{l}\text { Type of } \\
\text { Document }\end{array}$ & Author/s & Title (Year) & Type of FI Indicator & Country & Households/Individuals \\
\hline Thesis & Robinson, H [143] & $\begin{array}{l}\text { Low income older adults' use of food pantries as a way } \\
\text { to cope with food insecurity. (2014) }\end{array}$ & 6 item USDA HFSSM & USA & Elderly \\
\hline Thesis & Goodman, L. G [103] & $\begin{array}{l}\text { Factors associated with food insecurity among women } \\
\text { in a small indigenous Canadian Arctic community. } \\
\text { (2008) }\end{array}$ & 18 item USDA HFSSM & Canada & Adults-women \\
\hline Thesis & Smith, J [144] & $\begin{array}{l}\text { The effect of resource cycling and food insecurity on } \\
\text { dietary intake and weight of low-income, single mothers } \\
\text { living in rural Louisiana. (2002) }\end{array}$ & 6 item USDA HFSSM & USA & Adults-women \\
\hline Thesis & Yates, J. T [145] & $\begin{array}{l}\text { Maternal depression and food insecurity during } \\
\text { pregnancy among Oregon women. (2008) }\end{array}$ & $\begin{array}{l}2005 \text { Oregon PRAMS single-item Food } \\
\text { Insecurity Measure }\end{array}$ & USA & Adults-women \\
\hline Thesis & Long, A [146] & $\begin{array}{l}\text { The impact of food insecurity on disordered eating and } \\
\text { impulsivity in African American women (2017) }\end{array}$ & $\begin{array}{l}\text { Household Food Insecurity Access Scale } \\
\text { (HFIAS), FAO }\end{array}$ & USA & Adults-women \\
\hline Thesis & Bakar, W [72] & $\begin{array}{c}\text { Measuring and exploring perspectives on food } \\
\text { insecurity. (2010) }\end{array}$ & 18 item USDA HFSSM & Australia & Households \\
\hline Thesis & Kirkpatrick, S [104] & $\begin{array}{c}\text { Household Food Insecurity in Canada: An Examination } \\
\text { of Nutrition Implications and Factors Associated with } \\
\text { Vulnerability. (2008) }\end{array}$ & 18 item USDA HFSSM & Canada & Households \\
\hline Thesis & Skinner, K [86] & $\begin{array}{l}\text { Prevalence and perceptions of food insecurity and } \\
\text { coping strategies in Fort Albany First Nation, Ontario. } \\
\text { (2013) }\end{array}$ & 18 item USDA HFSSM & Canada & Households \\
\hline Thesis & Calhoun, M.D [87] & $\begin{array}{l}\text { Food insecurity in urban and rural settings: A mixed } \\
\text { methods analysis of risk factors and health. (2013). }\end{array}$ & 18 item USDA HFSSM & Canada & Households \\
\hline Thesis & Zahariuk. S [88] & $\begin{array}{l}\text { Food insecurity within the Island Lake first nation } \\
\text { communities in Northern Manitoba, Canada. (2014) }\end{array}$ & 18 item USDA HFSSM & Canada & Households \\
\hline Thesis & Leroux, J [92] & $\begin{array}{c}\text { Household Food Insecurity Among Older People in } \\
\text { Canada: the Exploration of a Public Health Issue } \\
\text { Rendered Invisible. (2018) }\end{array}$ & 18 item USDA HFSSM & Canada & Households \\
\hline Thesis & Mak. J [93] & Food insecurity during pregnancy in Canada. (2019) & 18 item USDA HFSSM & Canada & Households \\
\hline Thesis & St-Germain, A.F. [94] & $\begin{array}{l}\text { Household food insecurity in Canada: Understanding } \\
\text { the economic circumstances and policy options. (2019) }\end{array}$ & 18 item USDA HFSSM & Canada & Households \\
\hline
\end{tabular}


Table 2. Cont

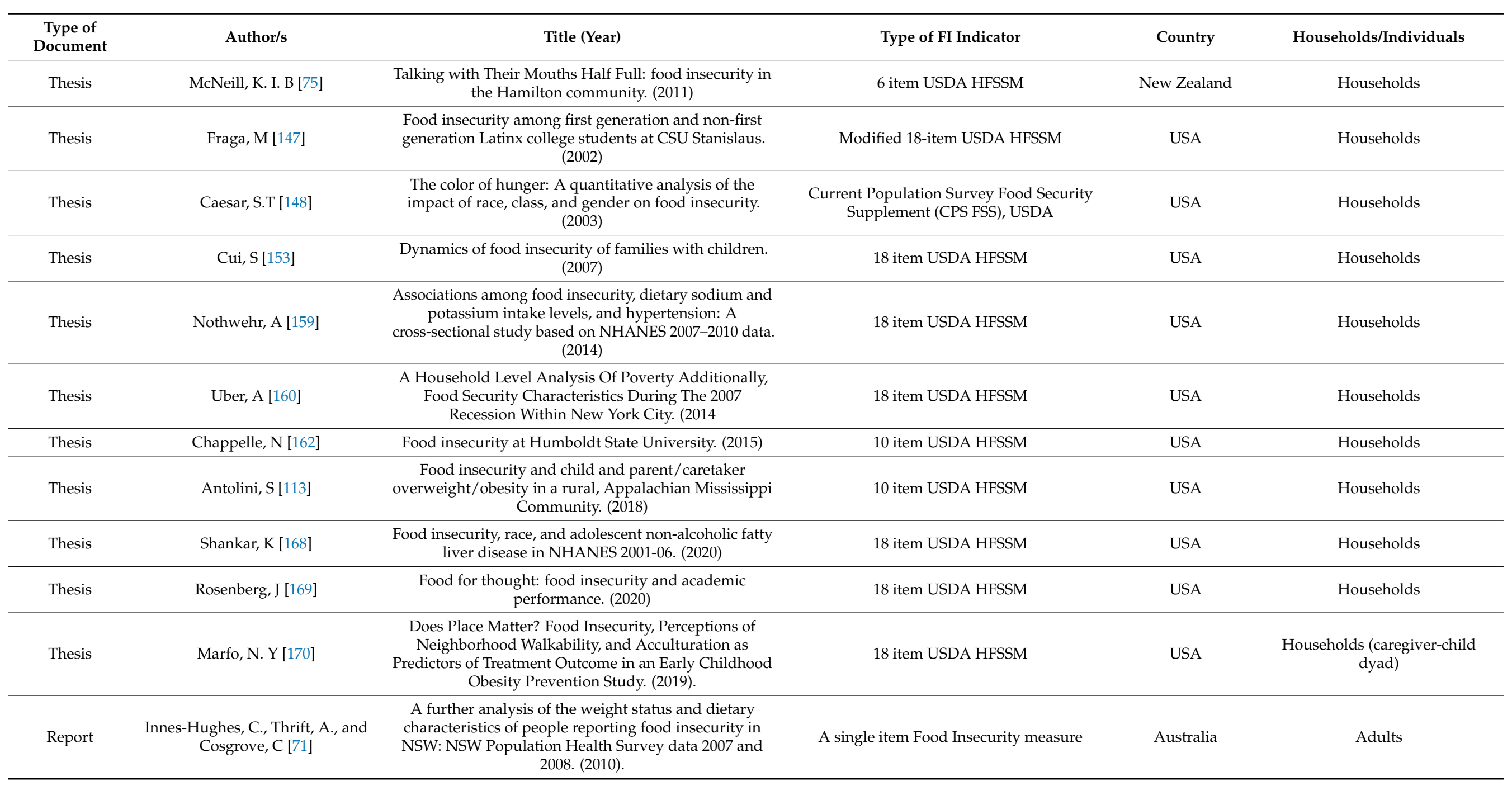


Table 2. Cont

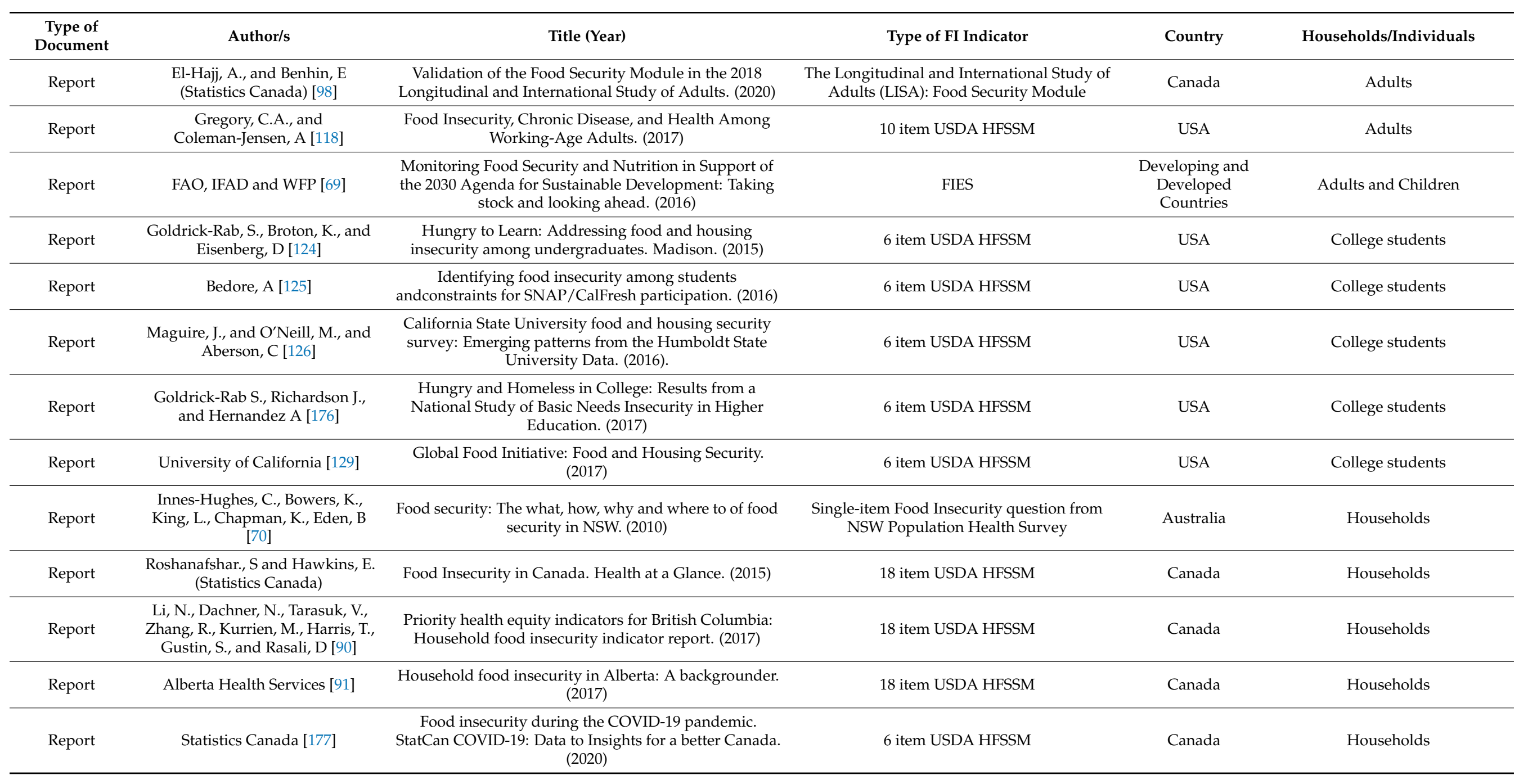


Table 2. Cont.

\begin{tabular}{|c|c|c|c|c|c|}
\hline $\begin{array}{l}\text { Type of } \\
\text { Document }\end{array}$ & Author/s & Title (Year) & Type of FI Indicator & Country & Households/Individuals \\
\hline Report & Statistics Canada [97] & $\begin{array}{c}\text { Household food insecurity, 2017/2018. Health fact } \\
\text { sheets. (2020) }\end{array}$ & 18 item USDA HFSSM & Canada & Households \\
\hline Report & Tarasuk, V., Mitchell A [96] & Household food insecurity in Canada, 2017-18. (2020) & 18 item USDA HFSSM & Canada & Households \\
\hline Report & $\begin{array}{l}\text { FAO, IFAD, UNICEF, WFP and } \\
\text { WHO [2] }\end{array}$ & $\begin{array}{l}\text { The state of food security and nutrition in the world } \\
\qquad 2021\end{array}$ & FIES & $\begin{array}{l}\text { Developing and } \\
\text { Developed } \\
\text { Countries }\end{array}$ & Households \\
\hline Report & $\begin{array}{l}\text { Bates, B., Roberts, C., Lepps, H., } \\
\text { and Porter, L [78] }\end{array}$ & The food and you survey: Wave 4. (2017) & 10 item USDA HFSSM & UK & Households \\
\hline Report & Loopstra. $\mathrm{R}$ & $\begin{array}{l}\text { Vulnerability to food insecurity since the COVID-19 } \\
\text { lockdown: Preliminary report. (2020) }\end{array}$ & 18 item USDA HFSSM & UK & Households \\
\hline Report & $\begin{array}{l}\text { Gundersen, C., and Ribar, D. C } \\
\text { [149] }\end{array}$ & $\begin{array}{l}\text { Food Insecurity and Insufficiency at Low Levels of Food } \\
\text { Expenditures (2005) }\end{array}$ & 18 item USDA HFSSM & USA & Households \\
\hline Report & Bartfeld, J., and Wang, L [151] & $\begin{array}{l}\text { Local-Level Predictors of Household Food Insecurity. } \\
\text { (2006) }\end{array}$ & 6-item USDA HFSSM & USA & Households \\
\hline Report & Nord, M [152] & $\begin{array}{l}\text { Characteristics of low-income households with very low } \\
\text { food security: An analysis of the USDA GPRA food } \\
\text { security indicator. (2007) }\end{array}$ & 18 item USDA HFSSM & USA & Households \\
\hline Report & Nord, M., and Golla, A.M [155] & $\begin{array}{c}\text { Does SNAP Decrease Food Insecurity? Untangling the } \\
\text { Self-Selection Effect. (2009) }\end{array}$ & modified 7-item USDA HFSSM & USA & Households \\
\hline Report & $\begin{array}{l}\text { Nord, M., Coleman-Jensen, A., } \\
\text { Andrews, M., and Carlson, S } \\
\text { [156] }\end{array}$ & $\begin{array}{l}\text { Household Food Security in the United States, } 2009 . \\
\qquad(2010)\end{array}$ & 18 item USDA HFSSM & USA & Households \\
\hline Report & $\begin{array}{l}\text { Coleman-Jensen, A., and Nord, } \\
\text { M [157] }\end{array}$ & $\begin{array}{l}\text { Food Insecurity Among Households With Working-Age } \\
\text { Adults With Disabilities (2013) }\end{array}$ & 18 item USDA HFSSM & USA & Households \\
\hline Report & $\begin{array}{l}\text { Nord, M., Coleman-Jensen, A., } \\
\text { and Gregory, C [158] }\end{array}$ & $\begin{array}{l}\text { Prevalence of U.S. Food Insecurity Is Related to Changes } \\
\text { in Unemployment, Inflation, and the Price of Food. } \\
\text { (2014) }\end{array}$ & 18 item USDA HFSSM & USA & Households \\
\hline Report & $\begin{array}{l}\text { Gregory, C.A., Coleman-Jensen, } \\
\text { A }\end{array}$ & $\begin{array}{c}\text { Food Insecurity, Chronic Disease, and Health Among } \\
\text { Working-Age Adults. (2017) }\end{array}$ & 10 item USDA HFSSM & USA & Households \\
\hline Report & $\begin{array}{l}\text { Coleman-Jensen, Alisha, } \\
\text { Matthew P. Rabbitt, Christian A. } \\
\text { Gregory, and Anita Singh [163] }\end{array}$ & $\begin{array}{l}\text { Household Food Security in the United States in } 2018 . \\
\text { (2019) }\end{array}$ & 18 item USDA HFSSM & USA & Households \\
\hline
\end{tabular}


Table 2. Cont.

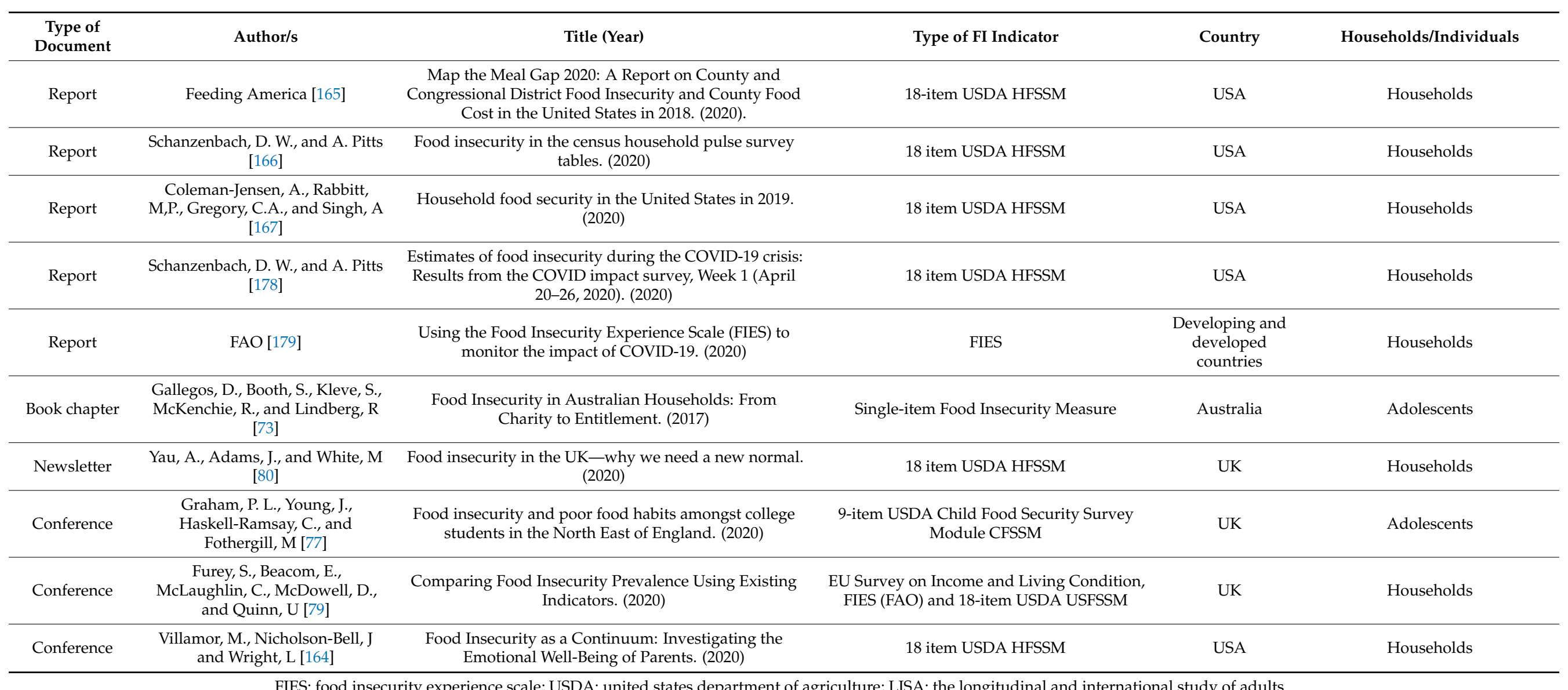

FIES: food insecurity experience scale; USDA: united states department of agriculture; LISA: the longitudinal and international study of adults. 


\subsection{Measures of Food Insecurity}

Overall, our literature review identified 23 measurement tools to assess food insecurity at the individual or household level in high-income countries (Table 3). The most used instruments are those of the USDA HFSSM which together $(6,10,18$ item versions) have been used in $71.8 \%$ percent of our sample. These are followed by the FIES (8\%), HFIAS (2.7\%) and the Single-item Food Insecurity question from the Australian NSW Population Health Survey ( $2 \%)$. The remaining 17 instruments were each used by one or two documents in our sample.

Table 3. Measures of food insecurity identified in this review, and frequency of use in the different studies.

\begin{tabular}{|c|c|c|}
\hline & \# & $\%$ \\
\hline 18 item USDA HFSSM & 58 & 38.9 \\
\hline 6-item USDA HFSSM & 34 & 22.8 \\
\hline 10 item USDA HFSSM/AFSSM & 15 & 10.1 \\
\hline FIES & 12 & 8.1 \\
\hline HFIAS & 4 & 2.7 \\
\hline Single-item Food Insecurity question from NSW Population Health Survey & 3 & 2.0 \\
\hline 9-item USDA Child Food Security Survey Module (CFSSM) & 2 & 1.3 \\
\hline Brazilian Food Insecurity Scale & 2 & 1.3 \\
\hline $\begin{array}{c}\text { European Quality of Life Survey item 'could your household afford a meal with meat, } \\
\text { chicken or fish every second day if you wanted it?' }\end{array}$ & 2 & 1.3 \\
\hline Radimer/Cornell Hunger and Food Insecurity Scale & 2 & 1.3 \\
\hline 2-item Food Insecurity Screening Questions (Hager et al., 2010) & 2 & 1.3 \\
\hline 2005 Oregon PRAMS single-item Food Insecurity Measure & 1 & 0.7 \\
\hline 8-item New Zealand Household Food Insecurity Measurement Tool & 1 & 0.7 \\
\hline Ad hoc single item FI measure ENEP & 1 & 0.7 \\
\hline Current Population Survey Food Security Supplement (CPS FSS), USDA & 1 & 0.7 \\
\hline Food Insecurity Index (FII) & 1 & 0.7 \\
\hline Food Security Survey Module (FSSM) & 1 & 0.7 \\
\hline Healthy Diets ASAP & 1 & 0.7 \\
\hline The Longitudinal and International Study of Adults (LISA): Food Security Module & 1 & 0.7 \\
\hline Household Hunger Scale & 1 & 0.7 \\
\hline Household Food and Nutrition Security Survey (HFNSS) & 1 & 0.7 \\
\hline Girard four point tool & 1 & 0.7 \\
\hline Kuyper past food insecurity & 1 & 0.7 \\
\hline Townsend Food Behaviour Checklist & 1 & 0.7 \\
\hline
\end{tabular}

Note. \#: number of times the instrument appears in the literature reviewed.

The majority of instruments identified in this study were developed by institutions with the purpose of monitoring food insecurity, its severity and its correlations in several contexts. The first tools (Radimer-Cornell FIM; 18-item, 10-item and 6-item HFSSM), date from the nineties, whereas more than half of the instruments have been developed since 2005.

In total, $74 \%$ of instruments in our sample were validated. Not validated measures or measures for which validation information has not been found include the Australian single-item, the 2005 Oregon PRAMS single-item, the ENEP single-item, the question in the European Quality of Life Survey, the Food Insecurity Index, and the Healthy Diets ASAP. We found that $65.2 \%$ of the existent instruments in our sample measure food insecurity at the household level, while $17.4 \%$ measure food insecurity at the individual level (10-item HFSSM/AFSSM, CFSSM, Townsend Food Behaviour Checklist, and ENEP single-item) and $17.4 \%$ at both the household and individual level (Girard four point tool, LISA Food Security Module, Australian single-item, 6-item HFSSM). The target population of the most commonly employed food insecurity instruments such as the US-HFSSM (18-item and 6-item) as well as the HFIAS and FIES include all age groups within the household, i.e., children, adults and the elderly. The CFSSM of the USDA is the only validated child food insecurity instrument for children and adolescents aged 12 years or above. There are some 
differences between the US-FSSM and CFSSM. The CFSSM has been developed from the HFSSM; however, the former is simple without any screeners, easier to understand and can be self-administered in older children and teenagers. The keywords in each of the nine items of the CFSSM (i.e., worry, run out, cheap food, etc.) are underlined in order to ensure that the child comprehends the question.

Regarding the dimensions of food insecurity captured by the different instruments in our sample, it was evident that all the instruments in our sample focus on accessibility and availability of food mostly related to financial constraints. The USDA's instruments specifically focus on the psychological aspects of food insecurity concerning worry or stress and anxiety over not being able to procure or consume sufficient food. On the other hand, the eight-item New Zealand Food Insecurity measurement tool along with focussing on the psychological aspects of food insecurity also question participants about food assistance from family or other sources and reliance on food banks. It is evident from the instruments in our sample that the majority of them (83\%) mainly focus on the quantity of food. Only $17 \%$ of the instruments in our sample, which include the Radimer Cornell Food Insecurity Measure, Brazilian Food Insecurity Scale, HFNSS and Healthy Diets ASAP, capture both the quantitative and qualitative aspects of food insecurity. Further, the Brazilian Food Insecurity Scale focusses on additional and interesting aspects of food insecurity including family expenses and food consumption while the Healthy Diets ASAP also covers the pricing of healthy food and drinks.

All the instruments in our sample have been developed in English including the Brazilian Food Insecurity Scale which was developed in Portuguese but includes an English version. $73.8 \%$ of instruments in our sample belong to the USDA which has developed different versions of its original HFSSM, including shorter versions and the self-reported module for older children or adolescents. The instruments in our sample have been most commonly used in the US (61\%).

As noted in Table 4, some of the instruments have a large number of items in order to capture the perceptions of food insecurity in participants more effectively. The HFNSS has 26 items in its instrument while the US-HFSSM and LISA Food Security Module have 18 items. On the other hand, there are some instruments only use a single item in order to measure food insecurity such as the NSW Population Health Survey, single item Australia, Oregon PRAMS, ENEP and EQLS. These instruments are simple and easy to employ yet may not be able to capture all aspects of food insecurity.

Most of the food insecurity instruments in our sample including all of the USDA's instruments have a time frame of either 30 days or 12 months. The psychometric properties of all validated instruments (74\%) in our sample have been found to be good. As noted in Table 4, we have identified several reported strengths of the different food insecurity instruments especially the US-HFSSM, which is considered to be a comprehensive survey that captures different levels of severity of food insecurity within the household. At the same time, various issues and unmet challenges have been described regarding these tools, which need to be addressed. The underlying issue that arises with most of these instruments including the US-HFSSM is that it does not capture the qualitative aspects of food insecurity. However, some of the challenges that have been found in these instruments are related to respondent burden due to the lengthy nature of the survey as in the case of the 18-item US-HFSSM, whereas shorter versions, like the Australian single-item FI indicator, may not adequately capture the intensity and complexity of food insecurity. Notwithstanding that, the main issue as in the case of the commonly used food insecurity indicators such as the US-HFSSM is related to the lack of items questioning the respondent about dietary quality. 
Table 4. Overview of measurement tools of food insecurity drawn upon in peer-reviewed articles and grey literature.

\begin{tabular}{|c|c|c|c|c|c|c|c|c|c|c|c|c|c|}
\hline Instrument & Author/s & Year & Language & $\begin{array}{c}\text { Original Purpose of } \\
\text { Development }\end{array}$ & $\begin{array}{l}\text { Unit to } \\
\text { Collect FI } \\
\text { Data }\end{array}$ & $\begin{array}{c}\text { Time } \\
\text { Frame of } \\
\text { FI Assess- } \\
\text { ment }\end{array}$ & $\begin{array}{l}\text { Dimensions } \\
\text { of FI }\end{array}$ & $\begin{array}{l}\text { Focus on } \\
\text { Qual- } \\
\text { ity/Quantity } \\
\text { of Food }\end{array}$ & $\begin{array}{c}\text { Number of } \\
\text { Items }\end{array}$ & $\begin{array}{c}\text { Response } \\
\text { Options }\end{array}$ & $\begin{array}{l}\text { Validity } \\
\text { Support }\end{array}$ & $\begin{array}{l}\text { Countries } \\
\text { Where It Has } \\
\text { Been Used }\end{array}$ & Respondents \\
\hline $\begin{array}{l}\text { HFIAS: } \\
\text { Household } \\
\text { Food } \\
\text { Insecurity } \\
\text { Access Scale } \\
\text { (HFIAS) for } \\
\text { Measurement } \\
\text { of Food } \\
\text { Access }\end{array}$ & FAO & 2007 & EN,ES,FR & $\begin{array}{l}\text { The Household Food } \\
\text { Insecurity Access Scale } \\
\text { (HFIAS) provides a } \\
\text { simple and user-friendly } \\
\text { approach for measuring } \\
\text { the impacts of } \\
\text { development food aid } \\
\text { programs on the access } \\
\text { component of household } \\
\text { food insecurity across } \\
\text { different cultural } \\
\text { contexts. It is to be used } \\
\text { especially in } \\
\text { resource-poor areas. The } \\
\text { information generated by } \\
\text { the HFIAS can be used to } \\
\text { assess the prevalence of } \\
\text { household food } \\
\text { insecurity (access } \\
\text { component) and to detect } \\
\text { changes in the food } \\
\text { insecurity situation of a } \\
\text { population over time. }\end{array}$ & Household & 4 weeks & Access & Quantity & $\begin{array}{c}9 \text { occurrence } \\
+9 \text { frequency } \\
\text { questions }\end{array}$ & $\begin{array}{l}\text { Dichotomous } \\
\text { (occurrence } \\
\text { questions) } \\
\text { Three-option } \\
\text { ordinal (frequency } \\
\text { questions), } \\
\text { which are } \\
\text { translated into } \\
\text { four-option } \\
\text { responses for each } \\
\text { of the nine } \\
\text { questions }\end{array}$ & $\begin{array}{l}\text { YesYes in } \\
\text { developing } \\
\text { countries- } \\
\text { although } \\
\text { used } \\
\text { universally }\end{array}$ & $\begin{array}{c}\text { Mostly } \\
\text { low-income } \\
\text { (but selected } \\
\text { references are } \\
\text { from US) }\end{array}$ & $\begin{array}{l}\text { All included } \\
\text { (household } \\
\text { approach) }\end{array}$ \\
\hline
\end{tabular}


Table 4. Cont.

\begin{tabular}{|c|c|c|c|c|c|c|c|c|c|c|c|c|c|}
\hline Instrument & Author/s & Year & Language & $\begin{array}{l}\text { Original Purpose of } \\
\text { Development }\end{array}$ & $\begin{array}{l}\text { Unit to } \\
\text { Collect FI } \\
\text { Data }\end{array}$ & $\begin{array}{c}\text { Time } \\
\text { Frame of } \\
\text { FI Assess- } \\
\text { ment }\end{array}$ & $\begin{array}{l}\text { Dimensions } \\
\quad \text { of FI }\end{array}$ & $\begin{array}{c}\text { Focus on } \\
\text { Qual- } \\
\text { ity/Quantity } \\
\text { of Food }\end{array}$ & $\begin{array}{l}\text { Number of } \\
\text { Items }\end{array}$ & $\begin{array}{l}\text { Response } \\
\text { Options }\end{array}$ & $\begin{array}{l}\text { Validity } \\
\text { Support }\end{array}$ & $\begin{array}{l}\text { Countries } \\
\text { Where It Has } \\
\text { Been Used }\end{array}$ & Respondents \\
\hline $\begin{array}{l}\text { FIES: Food } \\
\text { Insecurity } \\
\text { Experience } \\
\text { Scale }\end{array}$ & FAO & 2013 & $\begin{array}{c}\text { EN, ES, FR } \\
\text { and Arabic } \\
\text { Translations } \\
\text { provided } \\
\text { for more } \\
\text { than } 170 \\
\text { languages } \\
\text { and } \\
\text { dialects }\end{array}$ & $\begin{array}{l}\text { The FIES can be used to } \\
\text { measure food security } \\
\text { across sociocultural } \\
\text { contexts for the following } \\
\text { purposes: } \\
\text { To assess the population } \\
\text { prevalence of food } \\
\text { insecurity (for both SDG } \\
\text { monitoring and national } \\
\text { use); To identify } \\
\text { vulnerable populations; } \\
\text { To guide and monitor the } \\
\text { effects of food security } \\
\text { policies and programs; } \\
\text { To identify risk factors } \\
\text { and consequences of } \\
\text { food insecurity }\end{array}$ & $\begin{array}{l}\text { Individual } \\
\quad \text { (but } \\
\text { applicable to } \\
\text { household if } \\
\text { the HH } \\
\text { version is } \\
\text { selected) }\end{array}$ & $\begin{array}{l}30 \text { days or } \\
12 \text { months }\end{array}$ & Access & Quantity & 8 & Dichotomous & Yes & $\begin{array}{l}\text { Globally } \\
\text { (all-income } \\
\text { countries) }\end{array}$ & $\begin{array}{l}\text { Adults, } \\
\text { elderly, } \\
\text { households } \\
\text { (includes } \\
\text { children) }\end{array}$ \\
\hline $\begin{array}{l}\text { 18-item } \\
\text { USDA } \\
\text { HFSSM }\end{array}$ & USDA & $\begin{array}{l}\text { first } \\
\text { imple- } \\
\text { mented } \\
\text { in 1995; } \\
\text { last } \\
\text { revised } \\
\text { in } 2012\end{array}$ & $\begin{array}{l}\text { EN, ES, } \\
\text { ZH, FA }\end{array}$ & $\begin{array}{l}\text { Initially, the tool was } \\
\text { intended to measure both } \\
\text { household food } \\
\text { insecurity and hunger. } \\
\text { The USDA made few } \\
\text { changes. They decided to } \\
\text { omit hunger as it is a } \\
\text { physiological concept } \\
\text { that cannot be measured. } \\
\text { Further, changes were } \\
\text { made in the food } \\
\text { insecurity labels (food } \\
\text { secure, low food security } \\
\text { and very low food } \\
\text { security). }\end{array}$ & Household & $\begin{array}{l}30 \text { days or } \\
12 \text { months }\end{array}$ & Access & $\begin{array}{l}\text { Mostly } \\
\text { quantity- } \\
\text { Only two } \\
\text { questions } \\
\text { focus on } \\
\text { balanced } \\
\text { meal and } \\
\text { low-cost food }\end{array}$ & 18 & $\begin{array}{l}\text { Multiple choice of } \\
\text { three stages with } \\
\text { screeners and } \\
\text { statements and } \\
\text { dichotomous } \\
\text { variables. }\end{array}$ & Yes & $\begin{array}{l}\text { USA, Canada, } \\
\text { UK, Australia }\end{array}$ & $\begin{array}{l}\text { Children, } \\
\text { adolescents, } \\
\text { adults } \\
\text { including } \\
\text { elderly }\end{array}$ \\
\hline
\end{tabular}


Table 4. Cont.

\begin{tabular}{|c|c|c|c|c|c|c|c|c|c|c|c|c|c|}
\hline Instrument & Author/s & Year & Language & $\begin{array}{l}\text { Original Purpose of } \\
\text { Development }\end{array}$ & $\begin{array}{l}\text { Unit to } \\
\text { Collect FI } \\
\text { Data }\end{array}$ & $\begin{array}{c}\text { Time } \\
\text { Frame of } \\
\text { FI Assess- } \\
\text { ment }\end{array}$ & $\begin{array}{l}\text { Dimensions } \\
\text { of FI }\end{array}$ & $\begin{array}{c}\text { Focus on } \\
\text { Qual- } \\
\text { ity/Quantity } \\
\text { of Food }\end{array}$ & $\begin{array}{l}\text { Number of } \\
\text { Items }\end{array}$ & $\begin{array}{l}\text { Response } \\
\text { Options }\end{array}$ & $\begin{array}{l}\text { Validity } \\
\text { Support }\end{array}$ & $\begin{array}{l}\text { Countries } \\
\text { Where It Has } \\
\text { Been Used }\end{array}$ & Respondents \\
\hline $\begin{array}{l}\text { 10-item } \\
\text { USDA } \\
\text { HFSSM or } \\
\text { AFSSM } \\
\text { (Adult Food } \\
\text { Security } \\
\text { Survey } \\
\text { Module) }\end{array}$ & USDA & $\begin{array}{l}\text { The } \\
\text { AFSSM } \\
\text { is based } \\
\text { on the } \\
\text { 18-item } \\
\text { US } \\
\text { HFSSM } \\
\text { imple- } \\
\text { mented } \\
\text { in 1995 } \\
\text { and } \\
\text { revised } \\
\text { in 2012. }\end{array}$ & EN, ES & Same as the other HFSSM & Adults & $\begin{array}{l}30 \text { days or } \\
12 \text { months }\end{array}$ & Access & $\begin{array}{l}\text { Mostly } \\
\text { quantity, with } \\
\text { some } \\
\text { questions } \\
\text { about quality }\end{array}$ & 10 & $\begin{array}{l}\text { Multiple choice } \\
\text { with } 3 \text { stages and } \\
\text { screeners and } \\
\text { dichotomous } \\
\text { variables }\end{array}$ & Yes & $\begin{array}{l}\text { USA, Canada, } \\
\text { UK }\end{array}$ & Adults \\
\hline $\begin{array}{l}\text { 9-item USDA } \\
\text { Child Food } \\
\text { Security } \\
\text { Survey } \\
\text { Module } \\
\text { (CFSSM) }\end{array}$ & USDA & $\begin{array}{l}\text { The } \\
\text { CFSSM } \\
\text { was } \\
\text { adapted } \\
\text { from the } \\
\text { 18-item } \\
\text { HFSSM } \\
\text { and de- } \\
\text { veloped } \\
\text { by re- } \\
\text { searchers } \\
\text { Connell } \\
\text { et al., } \\
2004 .\end{array}$ & EN, ES & Same as the other HFSSM & $\begin{array}{l}\text { Children } \\
\text { (adolescents) } \\
\text { aged } 12 \text { years } \\
\text { and older }\end{array}$ & $\begin{array}{l}30 \text { days or } \\
12 \text { months }\end{array}$ & Access & $\begin{array}{c}\text { Mostly } \\
\text { quantity, with } \\
\text { some } \\
\text { questions } \\
\text { about quality }\end{array}$ & 9 & $\begin{array}{l}\text { Multiple choice } \\
\text { with statements. }\end{array}$ & Yes & $\begin{array}{l}\text { USA, UK, } \\
\text { Spain }\end{array}$ & Adolescents \\
\hline
\end{tabular}


Table 4. Cont.

\begin{tabular}{|c|c|c|c|c|c|c|c|c|c|c|c|c|c|}
\hline Instrument & Author/s & Year & Language & $\begin{array}{l}\text { Original Purpose of } \\
\text { Development }\end{array}$ & $\begin{array}{l}\text { Unit to } \\
\text { Collect FI } \\
\text { Data }\end{array}$ & $\begin{array}{c}\text { Time } \\
\text { Frame of } \\
\text { FI Assess- } \\
\text { ment }\end{array}$ & $\begin{array}{l}\text { Dimensions } \\
\text { of FI }\end{array}$ & $\begin{array}{l}\text { Focus on } \\
\text { Qual- } \\
\text { ity/Quantity } \\
\text { of Food } \\
\end{array}$ & $\begin{array}{l}\text { Number of } \\
\text { Items }\end{array}$ & $\begin{array}{l}\text { Response } \\
\text { Options }\end{array}$ & $\begin{array}{l}\text { Validity } \\
\text { Support }\end{array}$ & $\begin{array}{l}\text { Countries } \\
\text { Where It Has } \\
\text { Been Used }\end{array}$ & Respondents \\
\hline $\begin{array}{l}\text { 6-item USDA } \\
\text { HFSSM }\end{array}$ & 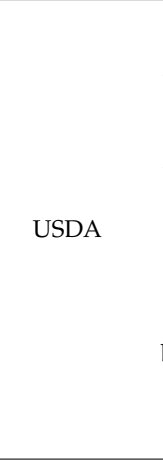 & $\begin{array}{c}\text { The } \\
\text { ques- } \\
\text { tions are } \\
\text { un- } \\
\text { changed } \\
\text { from the } \\
\text { survey } \\
\text { imple- } \\
\text { mented } \\
\text { in } 1995 \\
\text { and de- } \\
\text { veloped } \\
\text { by Blum- } \\
\text { berg } \\
\text { et al., } \\
1999 .\end{array}$ & EN & Same as the other HFSSM & $\begin{array}{c}\text { Household } \\
\text { and } \\
\text { individual }\end{array}$ & $\begin{array}{l}30 \text { days or } \\
12 \text { months }\end{array}$ & Access & $\begin{array}{c}\text { Mostly } \\
\text { quantity, with } \\
\text { some } \\
\text { questions } \\
\text { about quality }\end{array}$ & 6 & $\begin{array}{l}\text { Multiple choice } \\
\text { with statements. }\end{array}$ & Yes & $\begin{array}{l}\text { USA, Canada, } \\
\text { UK, New } \\
\text { Zealand, } \\
\text { Spain }\end{array}$ & $\begin{array}{l}\text { Adults } \\
\text { (individual or } \\
\text { household) }\end{array}$ \\
\hline $\begin{array}{l}\text { Household } \\
\text { Hunger Scale } \\
\text { (HHS) }\end{array}$ & FAO/FANTA & A 2011 & EN, ES, FR & $\begin{array}{l}\text { This questionnaire } \\
\text { departs from HFIAS in } \\
\text { order to develop a tool } \\
\text { that is applicable to } \\
\text { identify food insecure } \\
\text { households cross-cultural } \\
\text { settings in developing } \\
\text { countries. }\end{array}$ & Household & 4 weeks & Access & Quantity & $\begin{array}{c}3 \text { occurrence } \\
+3 \text { frequency } \\
\text { questions }\end{array}$ & $\begin{array}{c}\text { Dichotomous } \\
\text { (occurrence } \\
\text { questions) } \\
\text { Three-option } \\
\text { ordinal (frequency } \\
\text { questions), } \\
\text { which are } \\
\text { translated into } \\
\text { four-option } \\
\text { responses for each } \\
\text { of the three } \\
\text { questions }\end{array}$ & $\begin{array}{l}\text { Yes for seven } \\
\text { diverse } \\
\text { contexts in } \\
\text { developing } \\
\text { countries, but } \\
\text { used globally }\end{array}$ & Europe & Household \\
\hline $\begin{array}{l}\text { Single item } \\
\text { Australia }\end{array}$ & $\begin{array}{l}\text { NSW } \\
\text { Popula- } \\
\text { tion } \\
\text { Health } \\
\text { Survey }\end{array}$ & 2007 & EN & $\begin{array}{l}\text { This single item of FI was } \\
\text { included in the NSW } \\
\text { Population Health } \\
\text { Survey along with a } \\
\text { series of other health } \\
\text { related questions }\end{array}$ & $\begin{array}{l}\text { Household of } \\
\text { adults aged } \\
16 \text { years and } \\
\text { older }\end{array}$ & 12 months & Access & Quantity & 1 & $\begin{array}{l}\text { Dichotomous. } \\
\text { Food insecure or } \\
\text { Food secure }\end{array}$ & YesNoNo & Australia & $\begin{array}{l}\text { Adults } \\
\text { (16 years and } \\
\text { older) }\end{array}$ \\
\hline
\end{tabular}


Table 4. Cont.

\begin{tabular}{|c|c|c|c|c|c|c|c|c|c|c|c|c|c|}
\hline Instrument & Author/s & Year & Language & $\begin{array}{l}\text { Original Purpose of } \\
\text { Development }\end{array}$ & $\begin{array}{l}\text { Unit to } \\
\text { Collect FI } \\
\text { Data }\end{array}$ & $\begin{array}{c}\text { Time } \\
\text { Frame of } \\
\text { FI Assess- } \\
\text { ment }\end{array}$ & $\begin{array}{l}\text { Dimensions } \\
\text { of FI }\end{array}$ & $\begin{array}{l}\text { Focus on } \\
\text { Qual- } \\
\text { ity/Quantity } \\
\text { of Food }\end{array}$ & $\begin{array}{c}\text { Number of } \\
\text { Items }\end{array}$ & $\begin{array}{c}\text { Response } \\
\text { Options }\end{array}$ & $\begin{array}{l}\text { Validity } \\
\text { Support }\end{array}$ & $\begin{array}{l}\text { Countries } \\
\text { Where It Has } \\
\text { Been Used }\end{array}$ & Respondents \\
\hline $\begin{array}{l}\text { LISA Food } \\
\text { Security } \\
\text { Module }\end{array}$ & $\begin{array}{l}\text { Statistics } \\
\text { Canada }\end{array}$ & 2020 & EN & $\begin{array}{l}\text { To identify the } \\
\text { prevalence and correlates } \\
\text { of food insecurity across } \\
\text { population groups }\end{array}$ & $\begin{array}{l}\text { Household, } \\
\text { individuals } \\
\text { (adults and } \\
\text { children) }\end{array}$ & 12 months & Access & $\begin{array}{c}\text { Mostly } \\
\text { quantity, with } \\
\text { some } \\
\text { questions } \\
\text { about quality }\end{array}$ & 18 & $\begin{array}{l}\text { Response options } \\
\text { are same as } \\
\text { HFSSM. The } \\
\text { modified } \\
\text { household scale } \\
\text { has an additional } \\
\text { FI status, i.e., food } \\
\text { insecure marginal }\end{array}$ & Yes & Canada & $\begin{array}{l}\text { Adults and } \\
\text { children }\end{array}$ \\
\hline $\begin{array}{l}\text { Radimer- } \\
\text { Cornell Food } \\
\text { Insecurity } \\
\text { Measure }\end{array}$ & $\begin{array}{l}\text { Radimer } \\
\text { et al. }\end{array}$ & 1990 & $\begin{array}{c}\text { EN, Malay, } \\
\text { Farsi, } \\
\text { French }\end{array}$ & $\begin{array}{l}\text { The first pathway dealt } \\
\text { with insufficient intake of } \\
\text { food and food restriction, } \\
\text { along with the physical } \\
\text { feelings associated with } \\
\text { being hungry. The } \\
\text { second pathway } \\
\text { included household } \\
\text { problems with food } \\
\text { supply, diet quality, } \\
\text { feelings regarding the } \\
\text { household food situation, } \\
\text { and what the household } \\
\text { did to alleviate issues } \\
\text { with lack of food }\end{array}$ & Household & $\begin{array}{l}\text { The } \\
\text { instrument } \\
\text { does not } \\
\text { use a } \\
\text { specific } \\
\text { reference } \\
\text { period }\end{array}$ & Access & $\begin{array}{l}\text { Mostly } \\
\text { quantity, with } \\
\text { some } \\
\text { questions } \\
\text { about quality }\end{array}$ & $\begin{array}{l}\text { There are } \\
\text { several } \\
\text { versions of } \\
\text { this } \\
\text { instrument } \\
\text { which have } \\
\text { been } \\
\text { shortened } \\
\text { including a } \\
\text { 2-item } \\
\text { version and a } \\
\text { single-item } \\
\text { version. }\end{array}$ & Dichotomous & Yes & USA & Households \\
\hline
\end{tabular}


Table 4. Cont.

\begin{tabular}{|c|c|c|c|c|c|c|c|c|c|c|c|c|c|}
\hline Instrument & Author/s & Year & Language & $\begin{array}{l}\text { Original Purpose of } \\
\text { Development }\end{array}$ & $\begin{array}{l}\text { Unit to } \\
\text { Collect FI } \\
\text { Data }\end{array}$ & $\begin{array}{c}\text { Time } \\
\text { Frame of } \\
\text { FI Assess- } \\
\text { ment }\end{array}$ & $\begin{array}{l}\text { Dimensions } \\
\text { of FI }\end{array}$ & $\begin{array}{l}\text { Focus on } \\
\text { Qual- } \\
\text { ity/Quantity } \\
\text { of Food }\end{array}$ & $\begin{array}{c}\text { Number of } \\
\text { Items }\end{array}$ & $\begin{array}{c}\text { Response } \\
\text { Options }\end{array}$ & $\begin{array}{l}\text { Validity } \\
\text { Support }\end{array}$ & $\begin{array}{l}\text { Countries } \\
\text { Where It Has } \\
\text { Been Used }\end{array}$ & Respondents \\
\hline $\begin{array}{l}\text { 2-item Food } \\
\text { Insecurity } \\
\text { Screening } \\
\text { Questions } \\
\text { (Hager et al., } \\
\text { 2010) }\end{array}$ & $\begin{array}{l}\text { Hager } \\
\text { et al., } \\
2010\end{array}$ & 2010 & EN, ES & $\begin{array}{l}\text { This instrument is the } \\
\text { validated and modified } \\
\text { version of the USDA's } \\
\text { 18-item HFSSM. } \\
\text { Considering that the } \\
\text { 18-item HFSSM is long } \\
\text { and time consuming, the } \\
\text { authors decided on } \\
\text { modifying the original } \\
\text { instrument to include } 2 \\
\text { items. }\end{array}$ & Household & 12 months & Access & Quantity & 2 & Dichotomous & Yes & USA & Households \\
\hline $\begin{array}{l}2005 \text { Oregon } \\
\text { PRAMS } \\
\text { single-item } \\
\text { Food } \\
\text { Insecurity } \\
\text { Measure }\end{array}$ & $\begin{array}{l}\text { Oregon } \\
\text { Prams } \\
\text { Survey }\end{array}$ & 2005 & EN & $\begin{array}{l}\text { The PRAMS survey was } \\
\text { developed for } \\
\text { households with mothers } \\
\text { and children. It was a } \\
\text { survey used to capture } \\
\text { maternal depression and } \\
\text { household FI. }\end{array}$ & $\begin{array}{l}\text { Household } \\
\text { (mothers and } \\
\text { babies) }\end{array}$ & 12 months & Access & Quantity & 1 & Dichotomous & $\mathrm{N} / \mathrm{A}$ & USA & $\begin{array}{c}\text { Households } \\
\text { (mothers and } \\
\text { babies) }\end{array}$ \\
\hline $\begin{array}{l}\text { Brazilian } \\
\text { Food } \\
\text { Insecurity } \\
\text { Scale (EBIA) }\end{array}$ & IBGE & $\begin{array}{l}2004 \text { (val- } \\
\text { idation) }\end{array}$ & $\begin{array}{l}\text { Portuguese, } \\
\text { English, } \\
\text { Guarani }\end{array}$ & $\begin{array}{l}\text { To identify the } \\
\text { prevalence and severity } \\
\text { of food insecurity }\end{array}$ & Household & $\begin{array}{l}\text { Different } \\
\text { reference } \\
\text { periods } \\
\text { including } 1 \\
\text { month, 3 } \\
\text { months, } \\
\text { etc. }\end{array}$ & Access & $\begin{array}{l}\text { Mostly } \\
\text { quantity, with } \\
\text { some } \\
\text { questions } \\
\text { about quality }\end{array}$ & 14 & Dichotomous & Yes & $\begin{array}{c}\text { Portugal, } \\
\text { Brazil }\end{array}$ & Households \\
\hline $\begin{array}{l}\text { Community } \\
\text { Childhood } \\
\text { Hunger } \\
\text { Identification } \\
\text { Project }\end{array}$ & $\begin{array}{l}\text { Wehler } \\
\text { et al. }\end{array}$ & 2004 & English & $\begin{array}{c}\text { Part of a survey } \\
\text { instrument to examine } \\
\text { the prevalence of hunger } \\
\text { among low-income } \\
\text { families. }\end{array}$ & Household & 12 months & Access & Quantity & 13 & Dichotomous & Yes & $\begin{array}{l}\text { USA, Canada, } \\
\text { New Zealand } \\
\text { and England }\end{array}$ & $\begin{array}{l}\text { Usually } \\
\text { households } \\
\text { though it has } \\
\text { also been } \\
\text { used to } \\
\text { measure FI in } \\
\text { individuals } \\
\text { (women) }\end{array}$ \\
\hline
\end{tabular}


Table 4. Cont.

\begin{tabular}{|c|c|c|c|c|c|c|c|c|c|c|c|c|c|}
\hline Instrument & Author/s & Year & Language & $\begin{array}{l}\text { Original Purpose of } \\
\text { Development }\end{array}$ & $\begin{array}{l}\text { Unit to } \\
\text { Collect FI } \\
\text { Data }\end{array}$ & $\begin{array}{c}\text { Time } \\
\text { Frame of } \\
\text { FI Assess- } \\
\text { ment }\end{array}$ & $\begin{array}{l}\text { Dimensions } \\
\text { of FI }\end{array}$ & $\begin{array}{l}\text { Focus on } \\
\text { Qual- } \\
\text { ity/Quantity } \\
\text { of Food }\end{array}$ & $\begin{array}{c}\text { Number of } \\
\text { Items }\end{array}$ & $\begin{array}{c}\text { Response } \\
\text { Options }\end{array}$ & $\begin{array}{l}\text { Validity } \\
\text { Support }\end{array}$ & $\begin{array}{l}\text { Countries } \\
\text { Where It Has } \\
\text { Been Used }\end{array}$ & Respondents \\
\hline $\begin{array}{l}\text { Household } \\
\text { Food and } \\
\text { Nutrition } \\
\text { Security } \\
\text { Survey } \\
\text { (HFNSS) }\end{array}$ & $\begin{array}{l}\text { Archer } \\
\text { et al. } \\
\text { (develop- } \\
\text { ment of } \\
\text { survey) }\end{array}$ & 2014 & English & $\begin{array}{l}\text { The HFNSS was } \\
\text { developed using a series } \\
\text { of focus groups and a } \\
\text { three-stage Delphi } \\
\text { survey. }\end{array}$ & Household & 12 months & Access & $\begin{array}{c}\text { Quantity and } \\
\text { quality }\end{array}$ & 26 & Dichotomous & Yes & Australia & Households \\
\hline $\begin{array}{l}\text { Girard four } \\
\text { point tool }\end{array}$ & $\begin{array}{l}\text { Girard } \\
\text { and } \\
\text { Sercia }\end{array}$ & 2013 & English & $\begin{array}{l}\text { It was developed by } \\
\text { Girard and Sercia to } \\
\text { measure changes in food } \\
\text { habits of first-generation } \\
\text { immigrants in Montreal. }\end{array}$ & $\begin{array}{l}\text { Household } \\
\text { and } \\
\text { individual }\end{array}$ & $\begin{array}{l}\text { Last few } \\
\text { weeks }\end{array}$ & Access & $\begin{array}{l}\text { Quantity and } \\
\text { financial } \\
\text { constraints }\end{array}$ & 4 & Dichotomous & Yes & Canada & Households \\
\hline $\begin{array}{l}\text { Kuyper past } \\
\text { food } \\
\text { insecurity }\end{array}$ & $\begin{array}{l}\text { Kuyper } \\
\text { et al. }\end{array}$ & 2006 & English & $\begin{array}{l}\text { The purpose of this } \\
\text { survey was to examine } \\
\text { whether past and current } \\
\text { food insecurity influence } \\
\text { child feeding practices, } \\
\text { especially those less } \\
\text { restrictive or more } \\
\text { indulgent practices }\end{array}$ & Household & $\begin{array}{l}\text { It asks } \\
\text { questions } \\
\text { about FI } \\
\text { since } \\
\text { childhood }\end{array}$ & $\begin{array}{l}\text { Access and } \\
\text { stability }\end{array}$ & Neutral & 7 & Dichotomous & Yes & USA & Households \\
\hline $\begin{array}{l}\text { Townsend } \\
\text { Food } \\
\text { Behaviour } \\
\text { Checklist }\end{array}$ & $\begin{array}{l}\text { Townsend } \\
\text { et al. }\end{array}$ & 2003 & English & $\begin{array}{l}\text { The purpose of this } \\
\text { survey was to assess } \\
\text { whether the respondent } \\
\text { was consuming enough } \\
\text { food based on a checklist } \\
\text { of healthy foods. It } \\
\text { included two FI } \\
\text { questions which asks the } \\
\text { respondent whether they } \\
\text { have enough to eat }\end{array}$ & Individual & $\begin{array}{l}\text { Before the } \\
\text { end of the } \\
\text { month }\end{array}$ & Access & Neutral & 2 & $\begin{array}{c}\text { Ordinal: } \\
\text { Four-point } \\
\text { categorical scale }\end{array}$ & Yes & USA & Individuals \\
\hline
\end{tabular}


Table 4. Cont.

\begin{tabular}{|c|c|c|c|c|c|c|c|c|c|c|c|c|c|}
\hline Instrument & Author/s & Year & Language & $\begin{array}{l}\text { Original Purpose of } \\
\text { Development }\end{array}$ & $\begin{array}{l}\text { Unit to } \\
\text { Collect FI } \\
\text { Data }\end{array}$ & $\begin{array}{c}\text { Time } \\
\text { Frame of } \\
\text { FI Assess- } \\
\text { ment }\end{array}$ & $\begin{array}{l}\text { Dimensions } \\
\text { of FI }\end{array}$ & $\begin{array}{l}\text { Focus on } \\
\text { Qual- } \\
\text { ity/Quantity } \\
\text { of Food }\end{array}$ & $\begin{array}{c}\text { Number of } \\
\text { Items }\end{array}$ & $\begin{array}{c}\text { Response } \\
\text { Options }\end{array}$ & $\begin{array}{l}\text { Validity } \\
\text { Support }\end{array}$ & $\begin{array}{l}\text { Countries } \\
\text { Where It Has } \\
\text { Been Used }\end{array}$ & Respondents \\
\hline $\begin{array}{l}\text { Pre-program } \\
\text { questionnaire } \\
\text { single item FI } \\
\text { measure } \\
\text { ENEP }\end{array}$ & ENEP & $\mathrm{N} / \mathrm{A}$ & English & $\begin{array}{l}\text { It employs a single item } \\
\text { FI measure which is a } \\
\text { part of a food literacy } \\
\text { behaviour checklist }\end{array}$ & Individual & Past month & Access & Quantity & 1 & N/A & N/A & USA & Individuals \\
\hline $\begin{array}{c}\text { European } \\
\text { Quality of } \\
\text { Life Survey } \\
\text { (EQLS) }\end{array}$ & $\begin{array}{c}\text { European } \\
\text { Founda- } \\
\text { tion for } \\
\text { the } \\
\text { Improve- } \\
\text { ment of } \\
\text { Living } \\
\text { and } \\
\text { Working } \\
\text { Condi- } \\
\text { tions } \\
\text { (Euro- } \\
\text { foun) }\end{array}$ & $\begin{array}{l}2003, \\
2007\end{array}$ & English & $\begin{array}{l}\text { It focuses on an aspect of } \\
\text { food consumption } \\
\text { (meat/chicken/fish) that } \\
\text { families economise on } \\
\text { during periods of } \\
\text { financial strain, and is } \\
\text { less subjective than other } \\
\text { measures }\end{array}$ & Household & 12 months & Access & Quantity & 1 & Dichotomous. & N/A & Europe & Individuals \\
\hline $\begin{array}{l}\text { Food } \\
\text { Insecurity } \\
\text { Index }\end{array}$ & $\begin{array}{l}\text { Bacon } \\
\text { and } \\
\text { Baker }\end{array}$ & 2017 & English & $\begin{array}{c}\text { To identify the } \\
\text { percentage of individuals } \\
\text { within a census tract who } \\
\text { are food insecure and its } \\
\text { correlates }\end{array}$ & Household & N/A & Access & N/A & N/A & N/A & N/A & USA & Household \\
\hline $\begin{array}{l}\text { Healthy Diets } \\
\text { ASAP }\end{array}$ & $\begin{array}{l}\text { Lee et al., } \\
2018\end{array}$ & 2018 & English & $\begin{array}{l}\text { The Healthy Diets ASAP } \\
\text { methods protocol was } \\
\text { developed to assess, } \\
\text { compare and monitor the } \\
\text { price and affordability of } \\
\text { healthy and current diets } \\
\text { among the general } \\
\text { population in Australia. }\end{array}$ & Household & $\begin{array}{l}\text { Fortnightly } \\
\text { recommen- } \\
\text { dation of } \\
\text { healthy } \\
\text { diet }\end{array}$ & $\begin{array}{l}\text { Availability } \\
\text { and acess }\end{array}$ & Quantity & N/A & N/A & Yes & Australia & Household \\
\hline
\end{tabular}




\section{Discussion}

Research on food insecurity in high-income countries is only increasing-as observed by the growing number of papers and other documents published in recent years. This trend actually reflects a highly noticeable social and health-related issue, which is the alarming volume of households and individuals in the rich world that cannot see their fundamental right to adequate food guaranteed, as recognized by the Universal Declaration of Human Rights [180]. In a more recent version, the Sustainable Development Goals (especially SDG 2 and 3) emphasize the relevance of tackling this situation-and in fact, the FIES Scale was developed as a tool to assess the progression of SDG2 [181]. It is also urgent to adequately assess and monitor the scope of food insecurity, as it is by better comprehending the extent, correlations, causes and consequences of such phenomena in the different contexts that it will be possible to provide the most adequate solutions. One of the biggest challenges to this endeavor is the complexity of the phenomenon of food insecurity itself, which, when considering all its dimensions (availability, access, use and stability), encompasses not only the entirety of the food system, but also the personal and household experiences of those suffering from it. In this way, it adds a layer of intricacy, as it mixes objective and subjective perspectives.

In our review, we have identified 23 instruments to assess food insecurity at the individual or household level in high-income countries. The most used instruments are those of the USDA HFSSM followed by the FIES, HFIAS and the Single-item Food Insecurity question from the Australian NSW Population Health Survey $[2,67,68,175]$. These scales assess the experience of food insecurity at the access dimension, either at the household or individual level. Assessing the experience of food insecurity means that it is the subjective perception of the respondents about food what is being considered (i.e., in the questions such as the HFIAS In the past four weeks, were you or any household member not able to eat the kinds of foods you preferred because of a lack of resources? or In the past four weeks, did you or any household member have to eat a limited variety of foods due to a lack of resources?). It is interesting to note that although some of the studies identified in this review focused on specific populations like women, college students or the elderly, the scales used are not unique for this target-something that in the case of the elderly might be considered, given their particular conditions [25].

The fact that the USDA HFSSM scales have been the most used in our sample (in more than $70 \%$ of the documents), is coherent with the point that we are studying food insecurity in high-income countries [2]. The FIES and HFIAS were initially conceived to be used in low-income countries, but they have also been used in high-income ones, either for comparative purposes [2,69] or for selected deprived areas or populations [59,182]. In any case, the three sets of scales share a high number of common items, since the HFIAS was developed based on the HFSSM scales and has, in turn, informed the development of the FIES scale together with the Latin American and Caribbean Food Security Scale (ELCSA) $[25,183]$. They differ from each other by including or not including aspects related to the possibility of satisfying one's (household) food preferences (HFIAS) or accessibility to nutritious food (HFSSM/FIES). In this sense, they collect information that refers to the contextualization aspects of the concept of food insecurity [17] since these seem to be elements more relevant to the subjective experience of food security in high-income societies - where availability of a wide variety of foods is guaranteed.

Since dietary intake is one of the main determinants of health [184], food insecurity must be considered a relevant axis of health inequalities, and dietary quality should be considered in any action developed to reduce it. Therefore, we agree with Shanks [185] that the measurement of dietary diversity (and we may add food quality) to characterize food insecurity is essential. This is in fact one of the missing points of current scales to measure food insecurity -in our review, only three of the instruments found assessed both quantity and quality aspects of food intake, and were the least used. Moreover, although there exist specific instruments to measure it (such as the Household Dietary Diversity Score), these instruments are yet not very much implemented. In that sense, special interest 
was observed among the instruments used in the literature to add items considering health and socioeconomic aspects related with food insecurity such as family income, expenses and food consumption, but also structural issues like social programs and policies, which should systematically be included in food insecurity studies.

Assessing dietary diversity entails a challenge that echoes some of the traditional disputes on the measurement of food insecurity [28], namely the use of objective or subjective/experiential scales. In this way, while being able to capture people's (and their household's) experiences of food insecurity is essential, characterizing adequate food intake requires using objective measures. It means that while questions like the FIES "You were unable to eat healthy and nutritious food?" or the HFSSM "(I/we) couldn't afford to eat balanced meals" provide information about the respondent's perceptions of their food access possibilities, it might not fully reflect what from a public health perspective would be considered a proper diet. Additionally, given how current food systems have evolved with the proliferation and accessibility of ultraprocessed foods, looking only at the number of food groups consumed may not suffice to gain a proper view of diet quality, and therefore it might be necessary to complement current food insecurity scales with other traditional food intake recalls such as food diaries, 24 or $72 \mathrm{~h}$ recalls or food frequency questionnaires. In addition, another important aspect to take into account is that access to drinking water (water security) is not valued.

The scales identified in this review focus on the access dimension of food insecurity, and efforts should be made to also capture the use dimension, as well as other relevant aspects such as the environment of adequate sanitation, health services and care, allowing for a healthy and active life which the FAO 2012's definition of food insecurity recognizes [14]. This is something that Pereira and colleagues [186] described in the case of children, and is applicable to the case of adults as well.

Of course, reaching such a rich amount of data on the different dimensions of food security and its determinants (and consequences) may be at odds with the practicalities of data collection. It is in this case that the range of options available-in terms of number of items and length of the scales-must be considered to obtain the more complete data, as compatible with the requirements and possibility of each study.

This review is not exempt from limitations. Mainly, the algorithm used to identify the literature uses the term "high-income countries", but no individual country name. In this way, some single-country studies may have not been identified. However, the inclusion of gray literature and the considerably sizeable sample make it a complete reference to provide a comprehensive view of the instruments used to measure individual and household food insecurity in high-income countries.

\section{Conclusions}

This work supplements and expands on previous reviews on measures of food insecurity in high-income countries by maximizing the searched databases, applying no limits to the nature of the measure (single-item, survey-based, etc.) and including scales used in studies published in the gray literature. In this way, it offers an updated and comprehensive catalogue of instruments to measure food insecurity at the individual and household level in high-income to be used by both researchers and practitioners.

As it has been previously recognized, no 'perfect single measure that captures all aspects of food insecurity' exists, but efforts should continue to improve our understanding of food insecurity, combining both objective and subjective elements of assessment. Therefore, this scoping review considered that further research is required in terms of (i) the creation and/or improvement of validated measurement for food insecurity in high-income countries, (ii) the incorporation of food quality and dietary intake items to assess the food use, and (iii) the consideration of aspects such as the household composition, the economic situation of the individuals and households, their use of social resources and food aid and their food literacy and competences. 
Supplementary Materials: The following are available online at https:/ / www.mdpi.com/article/ 10.3390 /ijerph18189829/s1, Supplementary file S1: search strategies.

Author Contributions: Conceptualization, E.C.-Á., B.S.-R., L.C.-T., R.M.-V.; analysis and data curation E.C.-Á., B.S.-R., L.C.-T., N.S.K.; writing-original draft preparation, E.C.-Á., N.S.K.; writingreview and editing, E.C.-Á., B.S.-R., L.C.-T., N.S.K., R.M.-V. All authors have read and agreed to the published version of the manuscript.

Funding: This research received no external funding.

Institutional Review Board Statement: Not applicable.

Informed Consent Statement: Not applicable.

Data Availability Statement: The data presented in this study are available on request from the corresponding author.

Conflicts of Interest: The authors declare no conflict of interest.

\section{References}

1. FAO. The State of Food Security and Nutrition in the World 2020. Transforming Food Systems for Affordable Healthy Diets; FAO: Rome, Italy, 2020.

2. FAO. The State of Food Security and Nutrition in the World 2020; FAO: Rome, Italy, 2021.

3. Penne, T.; Goedemé, T. Can low-income households afford a healthy diet? Insufficient income as a driver of food insecurity in Europe. Food Policy 2021, 99, 101978. [CrossRef]

4. Loopstra, R.; Reeves, A.; Tarasuk, V. The rise of hunger among low-income households: An analysis of the risks of food insecurity between 2004 and 2016 in a population-based study of UK adults. J. Epidemiol. Community Heal. 2019, 73, 668-673. [CrossRef] [PubMed]

5. Pool, U.; Dooris, M. Prevalence of food security in the UK measured by the Food Insecurity Experience Scale. J. Public Health (Oxf). 2021, 1-8. [CrossRef]

6. Gundersen, C.; Hake, M.; Dewey, A.; Engelhard, E. Food Insecurity during COVID-19. Appl. Econ. Perspect. Policy 2021, 43, 153-161. [CrossRef] [PubMed]

7. Gundersen, C.; Ziliak, J.P. Food insecurity and health outcomes. Health Aff. 2015, 34, 1830-1839. [CrossRef] [PubMed]

8. Elgar, F.J.; Pickett, W.; Pförtner, T.K.; Gariépy, G.; Gordon, D.; Georgiades, K.; Davison, C.; Hammami, N.; MacNeil, A.H.; Da Silva, M.A.; et al. Relative food insecurity, mental health and wellbeing in 160 countries. Soc. Sci. Med. 2021, 268, 113556. [CrossRef]

9. Hadley, C.; Crooks, D.L. Coping and the biosocial consequences of food insecurity in the 21st century. Yearb. Phys. Anthropol. 2012, 149, 72-94. [CrossRef]

10. Mintz, S.W.; Bois, C.M.D. The Anthropology of food and eating. Annu. Rev. Anthropol. 2003, 31, 99-119. [CrossRef]

11. Pottier, J. Anthropology of Food: The Social Dynamics of Food Security; Polity Press: Cambridge, UK, 1999.

12. World Bank. Poverty and Hunger: Issues and Options for Food Security in Developing Countries; World Bank: Washington, DC, USA, 1986.

13. FAO. Rome Declaration on World Food Security and World Food Summit Plan of Action Rome Declaration on World Food Security; Food and Agriculture Organization: Rome, Italy, 1996.

14. Committee on World Food Security Coming to terms with terminology. Food security, Nutrition Security, Food Security and Nutrition, Food and Nutrition Security; Food and Agriculture Organization: Rome, Italy, 2012.

15. Barlow, P.; Loopstra, R.; Tarasuk, V.; Reeves, A. Liberal trade policy and food insecurity across the income distribution: An observational analysis in 132 countries, 2014-17. Lancet Glob. Heal. 2020, 8, e1090-e1097. [CrossRef]

16. Castetbon, K. Measuring food insecurity. In Sustainable Nutrition in a Changing World; Biesalski, H., Drewnowski, A., Dwyer, J., Strain, J., Weber, P., Eggersdorfer, M., Eds.; Springer: Cham, Switzerland, 2017. [CrossRef]

17. Anderson, S. (Ed.) Core indicators of nutritional state for difficult-to-sample populations. J. Nutr. 1990, 120, 1559-1600. [CrossRef]

18. FAO. An Introduction to the Basic Concepts of Food Security; FAO: Rome, Italy, 2008.

19. Deitchler, M.; Ballard, T.; Swindale, A.; Coates, J. Introducing a Simple Measure of Household Hunger for Cross-Cultural Use; Technical note No 12; USAID: Washington, DC, USA, 2011.

20. Mook, L.; Murdock, A.; Gundersen, C. Food Banking and Food Insecurity in High-Income Countries. Volunt. Int. J. Volunt. Nonprofit Organ. 2020, 31, 833-840. [CrossRef]

21. Nguyen, G.; Aucott, L.; McNeill, G.; Douglas, F. Identifying a potential tool to measure household food insecurity in the UK: A systematic review. Proc. Nutr. Soc. 2017, 76, E184. [CrossRef]

22. Beacom, E.; Furey, S.; Hollywood, L.; Humphreys, P. Investigating food insecurity measurement globally to inform practice locally: A rapid evidence review. Crit. Rev. Food Sci. Nutr. 2020. [CrossRef] [PubMed]

23. Ashby, S.; Kleve, S.; McKechnie, R.; Palermo, C. Measurement of the dimensions of food insecurity in developed countries: A systematic literature review. Public Health Nutr. 2016, 19, 2887-2896. [CrossRef]

24. McKay, F.H.; Haines, B.C.; Dunn, M. Measuring and Understanding Food Insecurity in Australia: A Systematic Review. Int. J. Environ. Res. Public Health 2019, 16, 476. [CrossRef] 
25. Marques, E.S.; Reichenheim, M.E.; De Moraes, C.L.; Antunes, M.M.L.; Salles-Costa, R. Household food insecurity: A systematic review of the measuring instruments used in epidemiological studies. Public Health Nutr. 2015, 18, 877-892. [CrossRef] [PubMed]

26. Pérez-Escamilla, R.; Segall-Corrêa, A.M. Food insecurity measurement and indicators. Rev Nutr. 2008, 21 (suppl), 15-26. [CrossRef]

27. Barrett, C.B. Measuring food insecurity. Science. 2010, 327, 825-828. [CrossRef]

28. Webb, P.; Coates, J.; Frongillo, E.A.; Lorge Rogers, B.; Swindale, A.; Bilinsky, P.; Friedman, D.R. Advances in Developing Country Food Insecurity Measurement; American Society of Nutrition: Rockville, MD, USA, 2006; pp. 1404S-1408S.

29. Arksey, H.; O'Malley, L. Scoping studies: Towards a methodological framework. Int. J. Soc. Res. Methodol. Theory Pract. 2005. [CrossRef]

30. Peters, M.D.J.; Godfrey, C.M.; Mcinerney, P.; Soares, C.B.; Khalil, H.; Parker, D. Methodology for JBI Scoping Reviews; Joanna Briggs Institute: South Adelaide, Australia, 2015; pp. 141-146.

31. Tricco, A.C.; Lillie, E.; Zarin, W.; O’Brien, K.K.; Colquhoun, H.; Levac, D.; Moher, D.; Peters, M.D.J.; Horsley, T.; Weeks, L.; et al. PRISMA extension for scoping reviews (PRISMA-ScR): Checklist and explanation. Ann. Intern. Med. 2018, 169, 467-473. [CrossRef]

32. Shamseer, L.; Moher, D.; Clarke, M.; Ghersi, D.; Liberati, A.; Petticrew, M.; Shekelle, P.; Stewart, L.A. PRISMA-P (Preferred Reporting Items for Systematic review and Meta-Analysis Protocols) 2015 checklist: Recommended items to address in a systematic review protocol. BMJ 2015. [CrossRef] [PubMed]

33. World Bank. World Bank Country and Lending Groups. Available online: https://datahelpdesk.worldbank.org/knowledgebase/ articles/906519\#High_income (accessed on 19 July 2021).

34. Grey Matters: A Practical Tool for Searching Health-Related Grey Literature; CADTH: Ottawa, ON, Canada, 2014.

35. Kalichman, S.C.; Grebler, T. Stress and poverty predictors of treatment adherence among people with low-literacy living with HIV/AIDS. Psychosom. Med. 2010, 72, 810-816. [CrossRef] [PubMed]

36. Gregório, M.J.; Graça, P.; Costa, A.; Nogueira, P.J.P.J.; Gregorio, M.J.; Graca, P.; Costa, A.; Nogueira, P.J. Time and regional perspectives of food insecurity during the economic crisis in Portugal, 2011-2013 | Perspectivas temporais e regionais da insegurança alimentar durante a crise econômica em Portugal, 2011-2013. Saude e Soc. 2014, 23, 1127-1141. [CrossRef]

37. Wang, J.; Tanaka, V.T.; Engelhard, G.; Rabbitt, M.P. An examination of measurement invariance using a multilevel explanatory rasch model. Measurement 2020, 18, 196-214. [CrossRef]

38. Grimaccia, E.; Naccarato, A. Food Insecurity in Europe: A Gender Perspective. Soc. Indic. Res. 2020, 21, 1-19. [CrossRef]

39. Grimaccia, E.; Naccarato, A. Confirmatory factor analysis to validate a new measure of food insecurity: Perceived and actual constructs. Qual. Quant. 2020, 54, 1211-1232. [CrossRef]

40. Park, J.Y.; Ville, A.S.; Schwinghamer, T.; Melgar-Quiñonez, H. Heterogeneous factors predict food insecurity among the elderly in developed countries: Insights from a multi-national analysis of 48 countries. Food Secur. 2019, 11, 541-552. [CrossRef]

41. Frongillo, E.A.; Nguyen, P.H.; Saha, K.K.; Sanghvi, T.; Afsana, K.; Haque, R.; Baker, J.; Ruel, M.T.; Rawat, R.; Menon, P. Large-scale behavior-change initiative for infant and young child feeding advanced language and motor development in a cluster-randomized program evaluation in bangladesh. J. Nutr. 2017, 147, 256-263. [CrossRef]

42. Broussard, N.H. What explains gender differences in food insecurity? Food Policy 2019, 83, 180-194. [CrossRef]

43. Davis, O.; Geiger, B.B. Did food insecurity rise across Europe after the 2008 crisis? An analysis across welfare regimes. Soc. Policy Soc. 2017, 16, 343-360. [CrossRef]

44. Jansen, E.; Lachman, J.M.; Heinrichs, N.; Hutchings, J.; Baban, A.; Foran, H.M. Hunger in Vulnerable Families in Southeastern Europe: Associations With Mental Health and Violence. Front. Public Heal. 2020, 8, 115. [CrossRef]

45. Gundersen, C. Understanding food insecurity in the USA and Canada: Potential insights for Europe. World Rev. Nutr. Diet. 2016, 115, 54-60. [CrossRef]

46. Koh, K.; Kaiser, M.L.; Sweeney, G.; Samadi, K.; Hyder, A. Explaining racial inequality in food security in Columbus, Ohio: A blinder-oaxaca decomposition analysis. Int. J. Environ. Res. Public Health 2020, 17, 5488. [CrossRef]

47. Jomaa, L.; Na, M.; Eagleton, S.G.; Diab-El-harake, M.; Savage, J.S. Caregiver's self-confidence in food resource management is associated with lower risk of household food insecurity among SNAP-Ed-eligible head start families. Nutrients 2020, 12, 2304. [CrossRef]

48. Nettle, D.; Bateson, M. Food-insecure women eat a less diverse diet in a more temporally variable way: Evidence from the us national health and nutrition examination survey, 2013-4. J. Obes. 2019, 1-9. [CrossRef] [PubMed]

49. Bacon, C.; Baker, G. The rise of food banks and the challenge of matching food assistance with potential need: Towards a spatially specific, rapid assessment approach. Agric. Human Values 2017, 34, 899-919. [CrossRef]

50. Begley, A.; Paynter, E.; Butcher, L.M.L.M.L.M.; Dhaliwal, S.S. Examining the association between food literacy and food insecurity. Nutrients 2019, 11, 445. [CrossRef] [PubMed]

51. Lee, A.; Lewis, M. Testing the price of healthy and current diets in remote aboriginal communities to improve food security: Development of the aboriginal and torres strait islander healthy diets ASAP (Australian standardised affordability and pricing) methods. Int. J. Environ. Res. Public Health 2018, 15, 2912. [CrossRef] [PubMed]

52. Graca, P.; Gregorio, M.J. Food insecurity and aging during economic crisis. Obes. Facts 2017, 10, 46-47. [CrossRef]

53. Gundersen, C.; Tarasuk, V.; Cheng, J.; De Oliveira, C.; Kurdyak, P. Food insecurity status and mortality among adults in Ontario, Canada. PLoS ONE 2018, 13, e0202642. [CrossRef] 
54. Li, N.N.; Dachner, N.; Tarasuk, V. The impact of changes in social policies on household food insecurity in British Columbia, 2005-2012. Prev. Med. (Baltim). 2016, 93, 151-158. [CrossRef] [PubMed]

55. Buscail, C.; Gendreau, J.; Daval, P.; Lombrail, P.; Hercberg, S.; Latino-Martel, P.; Julia, C. Impact of fruits and vegetables vouchers on food insecurity in disadvantaged families from a Paris suburb. BMC Nutr. 2019, 5, 26. [CrossRef] [PubMed]

56. Petralias, A.; Papadimitriou, E.; Riza, E.; Karagas, M.R.; Zagouras, A.B.A.; Linos, A. The impact of a school food aid program on household food insecurity. Eur. J. Public Health 2016, 26, 290-296. [CrossRef]

57. Zaçe, D.; Hoxhaj, I.; Pasciuto, T.; D'Anna, R.; Straface, G.; Reali, L.; De Santis, M.; Di Pietro, M.L. Association of maternal food insecurity before and during pregnancy with fetal structural anomalies: A multicenter case-control study protocol. Nutr. Health 2020. [CrossRef]

58. Henjum, S.; Morseth, M.S.; Arnold, C.D.; Mauno, D.; Terragni, L. "I worry if I will have food tomorrow": A study on food insecurity among asylum seekers living in Norway. BMC Public Health 2019, 19, 592. [CrossRef] [PubMed]

59. Poczta-Wajda, A.; Sapa, A.; Stepien, S.; Borychowski, M.; Stępień, S.; Borychowski, M. Food insecurity among small-scale farmers in Poland. Agric. 2020, 10, 295. [CrossRef]

60. Radimer, K.L. Measurement of household food security in the USA and other industrialised countries. Public Health Nutr. 2002, 5, 859-864. [CrossRef]

61. Maynard, M.; Andrade, L.; Packull-McCormick, S.; Perlman, C.M.; Leos-Toro, C.; Kirkpatrick, S.I. Food insecurity and mental health among females in high-income countries. Int. J. Environ. Res. Public Health 2018, 15, 1424. [CrossRef] [PubMed]

62. Frongillo, E.; Nguyen, H.T.; Smith, M.D.; Coleman-Jensen, A. Food insecurity is more strongly associated with poor subjective well-being in more-developed countries than in less-developed countries. J. Nutr. 2019, 149, 330-335. [CrossRef]

63. Brown, N.; Smith, J.; Brasher, A.; Risius, D.; Marczyk, A.; Wakefield-Scurr, J. Breast education for schoolgirls; why, what, when, and how? Breast J. 2018, 24, 377-382. [CrossRef]

64. Carter, M.A.; Dubois, L.; Tremblay, M.S. Place and food insecurity: A critical review and synthesis of the literature. Public Health Nutr. 2014, 17, 94-112. [CrossRef]

65. Brown, E.; Tarasuk, V. Money speaks: Reductions in severe food insecurity follow the canada child benefit. Prev. Med. (Baltim). 2019, 129, 105876. [CrossRef] [PubMed]

66. Zace, D.; de Waure, C.; Teleman, A.; Reali, L.; di Pietro, M.L. Prevalence of Italian children living in food insecure households and their health status. Eur. J. Public Health 2019, 29. [CrossRef]

67. Brown, K.M.; Elliott, S.J.; Robertson-Wilson, J.; Vine, M.M.; Leatherdale, S.T. "Now what?" perceived factors influencing knowledge exchange in school health research. Health Promot. Pract. 2018, 19, 590-600. [CrossRef] [PubMed]

68. Park, J.Y. Food Insecurity among the Elderly in Developed Countries: Insights From a Multi-National Analysis. Master's Thesis, McGill University, Montréal, QC, Canada, 2019.

69. FAO; IFAD; WFP. Monitoring Food Security and Nutrition in Support of the 2030 Agenda for Sustainable Development. FAO: Rome, Italy, 2016.

70. Innes-Hughes, C.; Bowers, K.; King, L.; Chapman, K.; Eden, B. Food Security: The What, Who, Why and Where to of Food Security in NSW; Technical Report; University of Sydney: Sidney, Australia, 2010.

71. Innes-Hughes, C.; Thrift, A.; Cosgrove, C. Monitoring update A Further Analysis of the Weight Status and Dietary Characteristics of People Reporting Food Insecurity in Nsw: Nsw Population Health Survey Data 2007 and 2008; Technical Report; University of Sydney: Sidney, Australia, 2010.

72. Bakar, W.A. Measuring and Exploring Perspectives on Food Insecurity. Ph.D. Thesis, University of Wollongong, Wollongwong, Australia, 2010.

73. Gallegos, D.; Booth, S.; Kleve, S.; McKenchie, R.; Kindeberg, R. Food Insecurity in Australian Households: From Charity to Entitlement. In A Sociology of Food an Nutrition. The Social Appetite; Germov, J., Williams, L., Eds.; Oxford University Press: Melbourne, Australia, 2017.

74. Ramsey, R. Food and Brisbane Households-Dietary, Health and Social Consequences of Food Insecurity. Ph.D. Thesis, Queensland University, Brisbane, Australia, 2011.

75. Mcneill, K. Talking with their Mouths Half Full: Food Insecurity in the Hamilton Community. Ph.D. Thesis, University of Waikato Hamilton, New Zealand, 2011.

76. Loopstra, R. Vulnerability to Food Insecurity since the COVID-19 Lockdown Preliminary Report; The Food Foundation: London, UK, 2020.

77. Graham, P.L.; Young, J.; Haskell-Ramsay, C.; Fothergill, M. Food insecurity and poor food habits amongst college students in the North East of England. In Proceedings of the 2nd UK Research Conference on Food and Poverty: Evidence for Change, Newcastle, UK, 24 June 2020.

78. Bates, B.; Roberts, C.; Lepps, H.; Porter, L. The food and you survey: Wave 4; Food Standards Agency: London, UK, 2017.

79. Furey, S.; Beacom, E.; McLaughlin, C.; McDowell, D.; Quinn, U. Comparing Food Insecurity Prevalence Using Existing Indicators - Ulster University. In Proceedings of the 2nd UK Research Conference on Food and Poverty: Evidence for Change, Newcastle, UK, 24 June 2020.

80. Yau, A.; Adams, J.; White, M. Food Insecurity in the UK-Why We Need a New Normal - MRC Epidemiology Unit. Available online: https://www.mrc-epid.cam.ac.uk/blog/2020/04/30/food-insecurity-need-new-normal/ (accessed on 29 July 2021).

81. Krishnan, N.S. Food Insecurity in Spanish Adolescents: Assessment and Associations with Psychological Wellbeing, Body Image and Disordered Eating. Ph.D. Thesis, Universitat Autònoma de Barcelona, Bellaterra, Spain, 2019. 
82. Garrido Carrasco, P.E. Intervención Educativa en Ancianos Receptores de un Servicio de Teleasisténcia Destinado al Incremento de Conocimientos Sobre Alimentación y Actividad Física y a la Reducción del Riesgo de Inseguridad Alimentaria, Malnutrición y Sedentarismo (Icaaf-Rimas). Ph.D. Thesis, Universitat de Barcelona, Barcelona, Spain, 2019.

83. Borowko, W. Food Insecurity among Working-Age Canadians with Disabilities. Master's Thesis, Simon Fraser University, Vancouver, BC, Canada, 2008.

84. Subnath, M. Indigenous Food Insecurity in Canada: An Analysis Using the 2012 Aboriginal Peoples Survey. Master's Thesis, Western Univeristy, London, ON, Canada, 2017.

85. McGuire, M. Poverty. Food Insecurity and Overweight/Obesity in the Canadian Population; StatCan: Ottawa, ON, Canada, 2008.

86. Skinner, K. Prevalence and Perceptions of Food Insecurity and Coping Strategies in Fort Albany First Nation, Ontario. Ph.D. Thesis, University of Waterloo, Waterloo, ON, Canada, 2013.

87. Calhoun, M.D. Food Insecurity in Urban and Rural Settings: A Mixed Methods Analysis of Risk Factors and Health. Ph.D. Thesis, University of Ottawa, Ottawa, ON, Canada, 2013.

88. Zahariuk, S. Food Insecurity within the Island Lake First Nation Communities in Northern Manitoba, Canada. Master's Thesis, University of Manitoba Winnipeg, Winnipeg, MB, Canada, 2014.

89. Roshanafshar, S.; Hawkins, E. Health at a Glance Food Insecurity in Canada; StatCan: Ottawa, ON, Canada, 2018.

90. Li, N.; Dachner, N.; Tarasuk, V.; Zhang, R.; Kurrien, M.; Harris, T.; Gustin, S.; Rasali, D. Priority Health Equity Indicators for British Columbia: Household Food Insecurity Indicator Report; Food Insecurity Policy Research: Vancouver, BC, Canada, 2017.

91. Alberta Health Services. Household Food Insecurity in Alberta; Alberta Health Services: Alberta, AB, Canada, 2017.

92. Leroux, J.S. Household Food Insecurity among Older People in Canada: The Exploration af a Public Health Issue Rendered Invisible. Ph.D. Thesis, Queen's University, Kingston, ON, Canada, 2018.

93. Mak, J. Food Insecurity during Pregnancy in Canada. Master's Thesis, University of Toronto, Toronto, ON, Canada, 2019.

94. St-germain, A.F. Household Food Insecurity in Canada: Understanding the Economic Circumstances and Policy Options Household Food Insecurity in Canada: Understanding the Economic Circumstances and Policy Options. Ph.D. Thesis, University of Toronto, Toronto, ON, Canada, 2019.

95. La Mantia, C. Diet Quality in Relation to Income, Education, and Food Insecurity Among Canadian Adults. Master's Thesis, University of Toronto, Toronto, ON, Canada, 2020.

96. Tarasuk, V.; Mitchell, A. Household Food Insecurity In Canada 2017; StatCan: Vancouver, BC, Canada, 2018.

97. Statistics Canada. Household food insecurity, 2017/2018. Health fact sheets; StatCan: Vancouver, BC, Canada, 2020.

98. El-hajj, A.; Benhin, E. Validation of the Food Security Module in the 2018 Longitudinal and International Study of Adults; Statistics Canada: Ottawa, ON, Canada, 2020.

99. Loopstra, R. Household Food Insecurity in Canada: Towards an Understanding of Effective Interventions. Ph.D. Thesis, University of Toronto, Toronto, ON, Canada, 2014.

100. Maynard, M. Experiences of Food Insecurity Among Undergraduate Students at the University of Waterloo: Barriers, Coping Strategies, and Perceived Health and Academic Outcomes. Master's Thesis, University of Waterloo, Waterloo, ON, Canada, 2016.

101. Hattangadi, N. Do University Students who Experience Food Insecurity Report Psychological Distress? Master's Thesis, University of Ontario Institute of Technology, Oshawa, ON, Canada, 2018.

102. Thirakul, N. An Analysis of the Prevalence and Predictors of Food Insecurity in Canadian Seniors. Master's Thesis, University of Toronto, Toronto, ON, Canada, 2019.

103. Goodman, L. Factors Associated with Food Insecurity among Women in a Small Indigenous Canadian Arctic Community. Master's Thesis, McGill University, Montreal, QC, Canada, 2008.

104. Kirkpatrick, S. Household Food Insecurity in Canada: An Examination of Nutrition Implications and Factors Associated with Vulnerability. Ph.D. Thesis, University of Toronto, Toronto, ON, Canada, 2008.

105. Goetz, J.R. Exploring Food Insecurity among Individuals with Serious Mental Illness: A Qualitative Study. Ph.D. Thesis, University of Kansas, Kansas City, MO, USA, 2008.

106. Stevenson, H.S. Food Security in New Zealand: The Relationship between Food Security, Ethnicity and Body Weight Status. Master's Thesis, University of Otago, Otago, New Zealand, 2011.

107. Mercado, V. Food and Housing Insecurity among Students at a Community College District. Ph.D. Thesis, San Francisco State University, San Francisco, CA, USA, 2017.

108. Kashuba, K. Development of a Food Program Design for the San Fernando Valley Rescue Mission to Improve Food Insecurity and Health Among Participants. Bachelor's Thesis, Robert D. Clark Honors College - University of Oregon, Oregon, OR, USA, 2017.

109. Eubanks, M.M. Prevalence of Food Insecurity within the University of Mississippi Community and Knowledge of and Opinions About the University of Mississippi Food Bank. Honour's Thesis, University of Mississippi, Mississippi, MS, USA, 2017.

110. Danek, A. Food Insecurity and Related Correlates among Students Attending Appalachian State University. Master's Thesis, Appalachian State University, Boone, NC, USA, 2017.

111. Harris, E.A. A Socio-Ecological Analysis of the Relationship between Eating Pathology and Food Insecurity. Master's Thesis, San Diego State University, San Diego, CA, USA, 2018.

112. Hagedorn, R. WISH4Campus: Evaluating College Food Insecurity and Promoting Solutions for Student Wellbeing. Ph.D. Thesis, West Virginia University, Morgantown, WV, USA, 2019. 
113. Antolini, S. Food Insecurity and Child and Parent/Caretaker Overweight/Obesity in a Rural, Appalachian Mississippi Community. Master's Thesis, University of Mississipi, Mississippi, MS, USA, 2018.

114. Goldston, G. An Examination of the Impact of the Supplemental Nutrition Assistance Program on Food Insecurity and Depression among Low-Income Adults Living in the United States. Bachelor's Thesis, Southern Connecticut State University, New Heaven, CT, USA, 2019.

115. Shirley, T. Food Insecurity and Produce Behaviors of Adults with Children in Rural, Appalachian Mississippi. Master's Thesis, University of Mississipi, Mississippi, MS, USA, 2019.

116. Pittman, S.E. Exploring Illinois Farmers' Food Insecurity Status. Master's Thesis, University of Illinois at Urbana-Champaign, Champaign, IL, USA, 2020.

117. Osborne, M. Gender Inequality in Food Insecurity: An Examination of Single Adults without Children in the United States. Master's Thesis, Oregon State University, Eugene, OR, USA, 2012.

118. Gregory, C.A.; Coleman-jensen, A. Food Insecurity, Chronic Disease, and Health Among Working-Age Adults; Economic Research Report No. ERR 235; USDA Economic Research Service: Washington, DC, USA, 2017.

119. Raja, A. Food insecurity and alcohol use in people with HIV infection and substance use disorder. Master's Thesis, University of Florida, Gainesville, FL, USA, 2017.

120. Burris, M. Food Insecurity and Age of Menarche: Using a Biocultural Approach and Life History Theory to Assess Risks of Food Insecurity among Girls in Tampa Bay, FL. Master's Thesis, University of South Florida, Tampa, FL, USA, 2018.

121. Nugent, M.A. Journeys to the Food Bank: Exploring the Experience of Food Insecurity among Postsecondary Students. Master's Thesis, University of Lethbridge, Lethbridge, AB, Canada, 2000.

122. Maroto, M. Food Insecurity among Community College Students: Prevalence and Relationship to Gpa, Energy, and Concentration. Ph.D. Thesis, Morgan State University, Baltimore, MD, USA, 2013.

123. Gorman, A. Food Insecurity Prevalence among College Students at Kent State University. Master's Thesis, Kent State University, Kent, OH, USA, 2014.

124. Goldrick-rab, S.; Bronton, K.; Eisenberg, D. Hungry to Learn: Addressing Food and Housing Insecurity among Undergraduates; Wisconsin Hope Lab Report; University of Wisconsin: Madison, WI, USA, 2015.

125. Bianco, S.; Jiang, M.; Stamper, N.; Paiva, M.; Abbiati, L.; Wolff, C. Identifying Food Insecure Students and Constraints for SNAP/CalFresh Participation at California State University, Chico; California State University: Chico, CA, USA, 2016.

126. Maguire, J.; Neill, M.O.; Aberson, C.; Mcclure, D.; Sw, H. California State University Food and Housing Security Survey: Emerging Patterns from the Humboldt State University Data; Humboldt State University: Arcata, CA, USA, 2016.

127. Macdonald, A. Food Insecurity and Educational A ainment at the University of Arkansas. Honour's Thesis, University of Arkansas, Fayetteville, AR, USA, 2016.

128. Ding, M. Food Insecurity and Undiagnosed Chronic Conditions among Adults. Master's Thesis, Auburn University, Auburn, AL, USA, 2012.

129. University of California. UC Global Food Initiative: Food and Housing Security at the University of California; University of California: Chico, CA, USA, 2017.

130. Camelo, K. Predictors of Food Insecurity and Their Relationship to Academic Achievement of College Students. Master's Thesis, University of Nevada, Reno, NV, USA, 2017.

131. Adamovic, E. Food Insecurity Among College Students: An Assessment of Prevalence and Solutions. Honour's Thesis, University of Colorado Boulder, Boulder, CO, USA, 2017.

132. Poll, K. Food Insecurity and Eating Behaviors of Collegiate Male Athletes. Master's Thesis, University of Mississipi, Mississippi, MS, USA, 2017.

133. Kim, E. The Acceptability and Feasibility of an On-Campus Food Pantry to Address Student Food Insecurity. Master's Thesis, Arizona State University, Tempe, AZ, USA, 2018.

134. Watson, T.D. Emerging Topics in Food Insecurity: An Assessment of University Student Food Access and Urban Agriculture in Los Angeles. Ph.D. Thesis, University of California Los Angeles (UCLA), Los Angeles, CA, USA, 2018.

135. Benefield, J. Food Insecurity and Health of International Students. Master's Thesis, University of Mississippi, Mississippi, MS, USA, 2019.

136. Weaver, C.G. Students' Perspectives of Strategies to Combat Food Insecurity on Campus. Master's Thesis, Auburn Univeristy, Auburn, AL, USA, 2018.

137. Que, S.B. Food Security as a Basic Right for College Students: A Descriptive Study of the Factors Associated with Food Insecurity and Higher Education Attainment. Master's Thesis, Abilene Christian University, Abilene, TX, USA, 2020.

138. Schichtl, R. Examining the Presence of Empathy in College Students as it Relates to Food Insecurity. Ph.D. Thesis, Texas Tech University, Lubbok, TX, USA, 2020.

139. Dinh, A.M. Effects of Food Insecurity on Fast Food Consumption A Cross Sectional Study Anh Mai Dinh. Master's Thesis, University of Washington, Seattle, WA, USA, 2012.

140. Fonseca, J.J. Dietary Consequences of Food Insecurity with Latino College Students in Rural America. Master's Thesis, Western Illinois University, Macomb, IL, USA, 2020.

141. Henniger, M. Food Insecurity at an Academic Health Campus: Estimating Need, Interest, and Opportunities for Food Assistance Interventions at the University of Oklahoma Health Sciences Center. Master's Thesis, University of Oklahoma, Stillwater, OK, USA, 2020. 
142. Anziano, J. Food Insecurity among College Athletes at a Public University in New England. Master's Thesis, Southern Connecticut State University, New Haven, CT, USA, 2020.

143. Robinson, H. Low-Income Older Adults' Use of Food Pantries as a Way to Cope with Food Insecurity 2014. Master's Thesis, Oklahoma State University, Stillwater, OK, USA, 2017.

144. Smith, J. The Effect of Resource Cycling and Food Insecurity on Dietary Intake and Weight of Low-Income, Single Mothers Living in Rural Louisiana. Master's Thesis, Louisiana State University, Baton Rouge, LA, USA, 2002.

145. Yates, J. Maternal Depression and Food Insecurity during Pregnancy among Oregon Women. Master's Thesis, Oregon Health and Science University, Portland, OR, USA, 2008.

146. Long, A. The Impact of Food Insecurity on Disordered Eating and Impulsivity in African-American Women. Master's Thesis, Alabama Agricultural \& Mechanical University, Huntsville, AL, USA, 2017.

147. Fraga, M. Food Insecurity among First Generation and Non-First Generation Latinx College Students at Csu Stanislaus. Master's Thesis, California State University, Turlock, CA, USA, 2020.

148. Caesar, S.T. The Color of Hunger: A Quantitative Analysis of the Impact of Race, Class, and Gender on Food Insecurity. Master's Thesis, California State University San Marcos, San Marcos, CA, USA, 2003.

149. Gundersen, C.; Ribar, D.C. Food Insecurity and Insufficiency at Low Levels of Food Expenditures; Discussion Paper No. 1594; Forschungsinstitut zur Zukunft der Arbeit Institute for the Study of Labor: Bonn, Germany, 2005.

150. Radean, T.A. Investigating the Link between Food Insecurity and Disturbances in Eating and Mood. Master's Thesis, Yale University, New Haven, CT, USA, 2014.

151. Bartfeld, J.; Wang, L. Local-level predictors of household food insecurity; Discussion Paper No. 1317-06; Institute for Research on Poverty: Madison, WI, USA, 2006.

152. Nord, M. Characteristics of Low-Income Households With Very Low Food Security An Analysis of the USDA GPRA Food Security Indicator; Economic Information Bulletin No EIB 25; USDA Economic Research Service: Washington, DC, USA, 2007 ; p. 27.

153. Cui, S. Dynamics of Food Insecurity of Families with Children. Master's Thesis, Iowa State University, Ames, IA, USA, 2007.

154. Nord, M.; Hopwood, H. A Comparison of Household Food Security in Canada and the United States; ERR-67; USDA Economic Research Service: Washington, DC, USA, 2008; p. 55.

155. Nord, M.; Golla, A. Does SNAP Decrease Food Insecurity? Untangling the Self-Selection Effect; ERR-85; USDA Economic Research Service: Washington, DC, USA, 2009; p. 23.

156. Nord, M.; Coleman-Jensen, A.; Andrews, M.; Carlson, S. Household Food Security in the United States, 2009; EER-108; USDA Economic Research Service: Washington, DC, USA, 2010.

157. Coleman-Jensen, A.; Nord, M. Food Insecurity Among Households With Working-Age Adults With Disabilities; EER-144; USDA Economic Research Service: Washington, DC, USA, 2013.

158. Nord, M.; Coleman-Jensen, A.; Gregory, C. Prevalence of U.S. Food Insecurity Is Related to Changes in Unemployment, Inflation, and the Price of Food; ERR-167; USDA Economic Research Service: Washington, DC, USA, 2014; p. 36.

159. Nothwehr, A. Associations among Food Insecurity, Dietary Sodium and Potassium Intake Levels, and Hypertension: A CrossSectional Study Based on Nhanes 2007-2010 Data. Master's Thesis, University of Maryland, College Park, MD, USA, 2014.

160. Uber, A. A Household Level Analysis of Poverty and Food Security Characteristics During the 2007 Recession Within New York City. Master's Thesis, Cornell University, Ithaca, NY, USA, 2014.

161. Guerra, S.A. Does Food Insecurity Predict Depression among Brazons Valley Residents? Ph.D. Thesis, Texas A\&M University, College Station, TX, USA, 2015.

162. Chapelle, N. Food insecurity at Humboldt State University. Master's Thesis, Humboldt State University, Arcata, CA, USA, 2015.

163. Coleman-Jensen, A.; Rabbitt, M.P.; Gregory, C.A.; Singh, A. Household Food Security in the United States in 2018; USDA Economic Research Service: Washington, DC, USA, 2019.

164. Villamor, M.; Nicholson-Bell, J.; Wright, L. Food Insecurity as a Continuum: Investigating the Emotional Well-Being of Parents SOARS Virtual Conference. Masters Thesis Research. Available online: https://unfsoars.domains.unf.edu/food-insecurity-as-acontinuum-investigating-the-emotional-well-being-of-parents / (accessed on 29 July 2021).

165. Feeding America. Map the Meal Gap 2020 A Report on County and Congressional District Food Insecurity and County Food Cost in the United States in 2018; Feeding America: Chicago, IL, USA, 2020.

166. Schanzenbach, D.; Pitts, A. Food Insecurity in the Census Household Pulse Survey Data Tables. Rapid Research Report; Northwestern Institute for Policy Research: Washington, DC, USA, 2020.

167. Coleman-Jensen, A.; Rabbitt, M.P.; Gregory, C.A.; Singh, A. Statistical Supplement to Household Food Security in the United States in 2017; USDA Economic Research Service: Washington, DC, USA, 2019.

168. Shankar, K. Food Insecurity, Race, and Adolescent Non-Alcoholic Fatty Liver disease in NHANES 2001-06. Master's Thesis, University of Connecticut, Mansfield, MA, USA, 2020.

169. Rosenberg, J. Food for Thought: Food Insecurity and Academic Performance. Master's Thesis, University of Central Florida, Orlando, FL, USA, 2020.

170. Marfo, N.Y. Does Place Matter? Food Insecurity, Perceptions of Neighborhood Walkability, and Acculturation as Predictors of Treatment Outcome in an Early Childhood Obesity Prevention Study. Master's Thesis, Univeristy of Connecticut, Mansfield, MA, USA, 2019.

171. Littler, N. Brain development education pathways. Br. J. Sch.Nurs. 2016, 11, 98-99. [CrossRef] 
172. Prezzato, E.L. Dietary Intake and Risk Factors Associated with Food Insecurity. Master's Thesis, San Diego State Univeristy, San Diego, CA, USA, 2015.

173. Rodriguez, P. Development of a Food Program Design for the San Fernando Valley Rescue Mission to Improve Food Insecurity and Health among Participants. Master's Thesis, California State University, Northridge, CA, USA, 2016.

174. Little, T.V. Language Proficiency, Citizenship, and Food Insecurity among Predominantly Immigrant Caribbean Latinos in Massachusetts. Master's Thesis, Univeristy of Massachusetts Medical School, Worcester, MA, USA, 2015.

175. Sydnor, M. Feed Me, House Me: Undergraduate College Students' Perspectives on Food and Housing Insecurity. Bachelor's Thesis, Ohio State University, Columbus, OH, USA, 2019.

176. Goldrick-Rab, S.; Richardson, J.; Hernandez, A. Hungry and Homeless in College; Wisconsin Hope Lab: Madison, WI, USA, 2017.

177. StatCan. Household food insecurity, 2017/2018; StatCan: Ottawa, ON, Canada, 2020.

178. Schanzenbach, D.; Pitts, A. Estimates of Food Insecurity During the COVID-19 Crisis: Results from the COVID Impact Survey; Rapid Research Report; Northwestern Institute for Policy Research: Evanston, IL, USA, 2020; Volume 1.

179. FAO. Using the Food Insecurity Experience Scale (FIES) to Monitor the Impact of COVID-19; FAO: Rome; Italy, $2020 ;$ pp. 146-152.

180. Naciones Unidas La Declaración Universal de Derechos Humanos; United Nations: Paris, France, 1948.

181. FAO. The Food Insecurity Experience Scale. Measuring Food Insecurity Through People's Experiences; FAO: Rome, Italy, 2017.

182. Raja, A.; Heeren, T.C.; Walley, A.Y.; Winter, M.R.; Mesic, A.; Saitz, R. Food insecurity and substance use in people with HIV infection and substance use disorder. Subst. Abus. 2020. [CrossRef]

183. INDDEX Project. Food Insecurity Experience Scale (FIES). Available online: https://inddex.nutrition.tufts.edu/data4diets/ indicator / food-insecurity-experience-scale-fies (accessed on 22 July 2021).

184. GBD 2017 Diet Collaborators Dietary risks_Level 2 risk. Available online: https://www.thelancet.com/pb-assets/Lancet/gbd/ summaries/risks/dietary-risks.pdf (accessed on 23 July 2021).

185. Byker Shanks, C.; Calloway, E.E.; Parks, C.A.; Yaroch, A.L. Scaling up measurement to confront food insecurity in the USA. Transl. Behav. Med. 2020, 10, 1382-1389. [CrossRef]

186. Pereira, A.L.; Handa, S.; Holmqvist, G. Prevalence and Correlates of Food Insecurity among Children across the Globe. OECDiLibrary 2017, 1-37. [CrossRef] 